UNIVERSIDADE DE SÃO PAULO

FACULDADE DE FILOSOFIA, LETRAS E CIENCIAS HUMANAS

DEPARTAMENTO DE LINGUÍSTICA

PROGRAMA DE POST-GRADUAÇÃO EM SEMIÓTICA E LINGÜÍSTICA GERAL

\title{
A categoria do tempo na língua espanhola: uma abordagem semiótica
}

Serafina Vallejo Gómez

Dissertação apresentada ao Programa de Post-Graduação em Lingüística e Semiótica do Departamento de Linguística da Faculdade de Filosofia, Letras e Ciências Humanas da Universidade de São Paulo, para obtenção do título de Mestre em Letras.

Orientador: $\operatorname{Prof}^{\mathrm{o}} \mathrm{Dr}^{\mathrm{o}}$ Antonio Vicente Seraphim Pietroforte

São Paulo

2007 
UNIVERSIDADE DE SÃO PAULO

FACULDADE DE FILOSOFIA, LETRAS E CIENCIAS HUMANAS

DEPARTAMENTO DE LINGUÍSTICA

PROGRAMA DE POST-GRADUAÇÃO EM SEMIÓTICA E LINGÜÍSTICA GERAL

\section{A categoria do tempo na língua espanhola: uma abordagem semiótica}

Serafina Vallejo Gómez

Dissertação apresentada ao Programa de Post-Graduação em Lingüística e Semiótica do Departamento de Linguística da Faculdade de Filosofia, Letras e Ciências Humanas da Universidade de São Paulo, para obtenção do título de Mestre em Letras.

Orientador: $\operatorname{Prof}^{\mathrm{o}} \mathrm{Dr}^{\mathrm{o}}$ Antonio Vicente Seraphim Pietroforte

São Paulo

2007 
$\mathcal{A}$ todas aquelas que chegaram até aqui, e às que tentaram também, às que no percurso tiveram filfos, trabalfaram na casa, ganharam dinheiro fora, largaram o amor da sua vida ou acharam um, às lutadoras, porque o futuro esta nas mãos delas e as mãos de uma mulher são muito grandes. 
Este trabalho não seria o que de fato é sem a ajuda e o apoio de algumas pessoas as quais merecem um agradecimento.

Ao meu orientador Antonio Vicente por jamais perder a confiança em mim. Ao professor Xoan pela calma que ele me transmitiu nos momentos de crise. A Vanessa pela companhia que suas páginas me fizeram.

A minha mãe por ser a origem e o principio de tudo. Ao meu pai porque dele aprendi o valor do trabalho. A eles que me ensinaram que o coração fica na esquerda e o vermelho é a sua cor e que sem isso é impossível viver com dignidade.

A Paqui por ser meu espelho. A Sandra pela magia. A Rosângela pelas boas vibrações. A Esther porque as suas sugestões iluminaram caminhos escuros. A Blas pelo duende que ele tem e que compartilha com todos. A Pepe por ser um homemmontanha, grande e generoso.

A Thelma e a Roberto por revisar o meu texto com profissionalismo e, sobretudo, com muito carinho.

A Claudinete pela muita dedicação com que nos cuida.

A Haritz pela paciência y a imensa compreensão de um menino de oito anos. A Amandi porque ninguém como ele vivenciou este trabalho desde tão dentro de mim.

A Estebe... porque sem ele eu seria a metade e com ele eu sou o dobro.

A tod@s aquel@s com quem compartilhei, troquei e discuti idéias.

A todos vocês, muito obrigada. 


\section{Resumo}

Aceitando que existe um tempo lingüístico distinto do tempo físico ou do tempo cronológico, este trabalho visa o estudo do sistema temporal no español utilizando como modelo teórico as propostas de José Luiz Fiorin em As astúcias da enunciação.

Desde o ponto de vista da teoria semiótica, adotada no presente trabalho, o sentido constrói-se por um percurso gerativo em três níveis: fundamental, narrativo e discursivo. A enunciação, como ato produtor de um enunciado, é a instância encarregada de instaurar no nível discursivo as categorias de pessoa, tempo e espaço. A partir do momento da enunciação estabelecem-se três momentos de referência, um momento de referência concomitante e dois não concomitantes com o momento da enunciação, o momento de referência da anterioridade e o momento de referência da posterioridade. Por sua vez cada um desses momentos de referência desdobram-se em momentos do acontecimento,

igualmente concomitantes e não concomitantes (anteriores e posteriores). Os tempos verbais que exprimem a relação de concomitância configuram o sistema enunciativo e os tempos que explicam a relação de não concomitância com o momento da enunciação conformam o sistema enuncivo.

São estudadas as relações dos tempos verbais do español a respeito do momento da enunciação e as diferentes posições que ocupam nos sistemas tanto enuncivo quanto enunciativo, os usos fundamentais e as possíveis neutralizações em determinados contextos ou em função da intenção do enunciador. A verificação do modelo teórico se faz extensiva às mudanças ocorridas tanto no estilo direto, o narrador delega a voz a um interlocutor, quanto no estilo indireto, na passagem de dois momentos de enunciação para um só. Não serão esquecidas as correlações temporais e as relações que os tempos do subjuntivo estabelecem com o verbo principal e, portanto, com o momento de referência dele.

Palavras chave: enunciação; enunciado; concomitância; anterioridade; posterioridade 


\section{Abstract}

Accepting there is a linguistic tense different from physical or chronological time, this work aims the studying of Spanish time system by using the theoretical model proposed by José Luiz Fiorin in his As astúcias da enunciação.

From the point of view of Semiotic theory, adopted in this work, the meaning is constructed by a generative process in several levels, fundamental, narrative and discursive. Enunciation, as a producer fact of a statement, is the instance in charge to initiate in a discursive level the categories of person, time and space. From the moment of enunciation they are created three moments of reference: one moment of concomitance reference and two non-concomitance with the moment of enunciation, the moment of anterior reference and the moment of posterior reference. At the same time, each one of these moments of reference is separated into moments of occurrence, equally concomitance and nonconcomitance (anterior and posterior). The verbal tenses that express the relationship of concomitance configure the enunciative system and verbal times express the relationship of not-concomitance configure the enuncive system.

First, they will be studied the relationship of Spanish verbal tenses regarding the moment of the enunciation and different positions they occupy in the systems both enuncive and enunciative. Second, they will be also studied the fundamental uses and possible verbal neutralizations in specific contexts or depending of the writer's intention. Finally, the verification of Fiorin model is extended to the changes done in the direct style, when the narrator delegates the voice to one interlocutor, as much as in the indirect style, when the two moments of enunciation become just one. They will not been forgotten time correlations and the relationship of the subjunctive tenses establish with the main verb; therefore, with the moment of its reference.

Key words: enunciation; statement; concomitant; anterior; posterior 


\section{Índice}

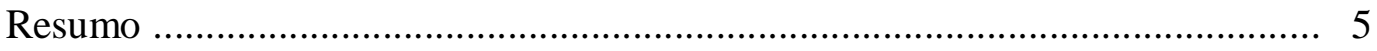

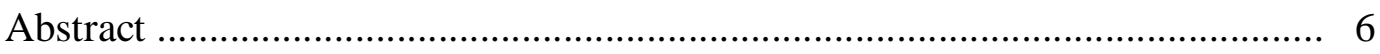

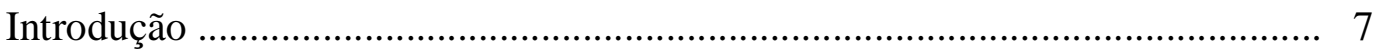

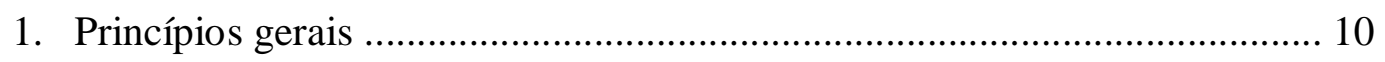

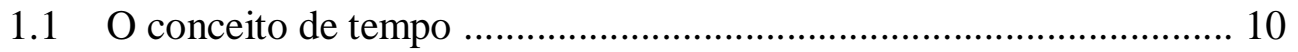

1.2 Tempo e discurso ....................................................................... 15

1.3 Passado e presente do espanhol ..................................................... 22

a) Aspectos diacrônicos ........................................................................ 22

b) Aspectos sincrônicos …………………………………………...... 25

c) Que español estudar ....................................................................... 28

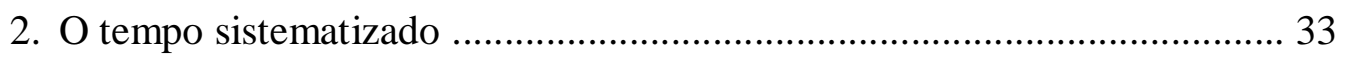

2.1 Os tempos verbais ............................................................................ 33

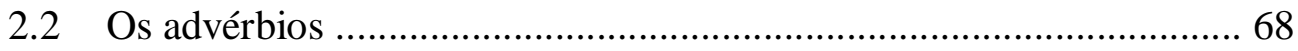

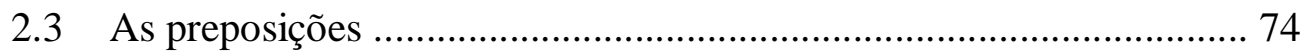

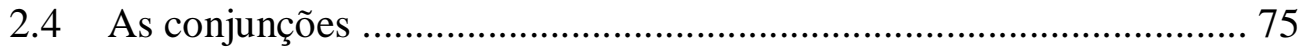

2.5 Pretérito perfecto simple e pretérito perfecto compuesto .................... 75

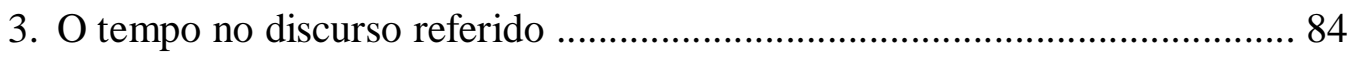

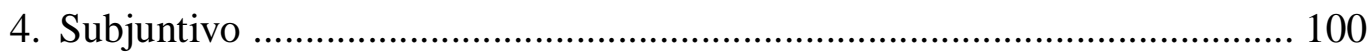

5. Embreagem temporal ........................................................................... 114

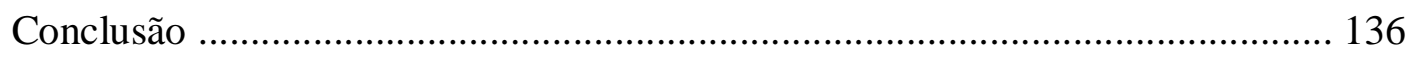

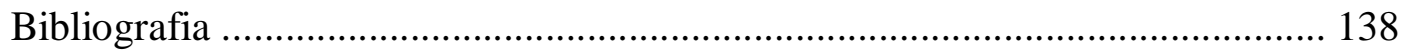




\section{Introdução}

Numerosos são os estudos referidos ao tempo como categoria lingüística, gramáticas e trabalhos específicos descrevem seus aspectos morfológicos, a função sintática, os usos fundamentais de suas formas e aqueles que adquirem em função da intenção do enunciador em diferentes contextos. Este trabalho tem como objetivo o estudo do tempo no discurso, expresso por diferentes categorias de palavras (verbo, advérbios, preposições, conjunções) segundo a teoria de José Luiz Fiorin em seu livro As astúcias da enunciação.

Desde o ponto de vista da teoria, semiótica adotada no presente trabalho, o sentido constroe-se por um percurso gerativo em vários níveis, fundamental, narrativo e discursivo. A enunciação, como ato produtor de um enunciado, é a instancia encarregada de instaurar no nível discursivo as categorias de pessoa, tempo e espaço. A partir do momento da enunciação estabelecem-se três momentos de referência, um momento de referência concomitante e dois não concomitantes com o momento da enunciação, o momento de referência da anterioridade e o momento de referência da posterioridade. Por sua vez cada um desses momentos de referência desdobram-se em momentos do acontecimento, igualmente concomitantes e não concomitantes (anteriores e posteriores). Dessa maneira são explicadas as relações temporais no sistema verbal do português no livro anteriormente mencionado de Fiorin, e assim serão explicadas as relações temporais do sistema verbal do español, objeto de estudo da nossa pesquisa.

Em primeiro lugar, será revisado o significado que o conceito de tempo possui de modo geral para ser comparado com o conceito de tempo lingüístico. A continuação, serão expostos os princípios gerais da teoria semiótica que fundamenta o trabalho realizado e alguns aspectos gerais sobre a história e difusão do español no mundo. O corpus escolhido para aplicação prática da teoria remete-se a obras literárias escritas por se tratar esses de textos inscritos na norma culta e por recolher exemplos de autores de diferentes nacionalidades do mundo hispânico, fato que confirma o español como uma língua que 
conserva a sua unidade ao tempo que respeita as próprias variantes. Não serão estudadas em profundidade as variantes, unicamente referidas nos casos em que o uso de algum tempo verbal o precise.

No segundo capítulo, será desenvolvido o sistema verbal do español, no modo indicativo, desde o ponto de vista da teoria semiótica. O modo indicativo será estudado em profundidade por ser esse o modo da expressão da realidade e por depender de ele as relações temporais tanto do subjuntivo como as do discurso referido. Não podendo esquecer das relações temporais que os advérbios criam a partir do momento da enunciação, será elaborado um esquema que as explique. Finalmente, faremos menção às preposições e às conjunções que expressam tempo.

Em seguida, serão abordadas as debreagens de segundo grau, o discurso direto. Neste capítulo, recolhem-se as mudanças que acontecer com o passo de um momento de nunciação para dos no discurso referido, estilo indireto.

Posteriormente, em outro capítulo, será estudado o modo subjuntivo no que diz respeito à concordância entre os tempos do modo indicativo e subjuntivo. Sem esquecer que o subjuntivo utiliza o momento de referência do verbo principal e articula-se em função dele, colocando os acontecimentos como anteriores, concomitantes ou posteriores a tal momento.

Por último serão apresentadas as neutralizações verbais, algumas delas de maneira teórica e outras exemplificadas. Finalizando com as conclusões gerais. 


\title{
1. Princípios gerais
}

\subsection{0 conceito de tempo}

\author{
El tiempo va sobre el sueño \\ hundido hasta los cabellos. \\ Ayer y mañana comen \\ oscuras flores de duelo.
}

F.G. Lorca

A preocupação do ser humano com o tempo é uma constante ao longo da história no pensamento filosófico, recorrente nos textos literários, na arte em geral. Determinar quando o ser humano teve uma noção de tempo talvez deveria remontar-se à pré-história, quando precisou estabelecer o ciclo das estações para assim poder cultivar a terra. Já os gregos dedicaram ao tempo um deus, Cronos, e os romanos, ao se apropriarem da cultura grega, mantiveram-no com o nome de Saturno, aquele que devora seus filhos assim que nascem do mesmo jeito que consome os anos e nunca se sacia. É assim como Cícero, no seu diálogo De Senectute, descreve Saturno. Relata que Júpiter, a fim de o conter, acorrentou-o, submetendo-o ao curso dos astros que são como laços que o prendem. A concepção que os clássicos tinham do tempo era cíclica, os dias que passam, as semanas que se sucedem, as estações que voltam, o círculo como forma perfeita de tudo alquilo que tinha um movimento natural. Já os hebreus tinham uma concepção do tempo linear. Aderiu-se a idéia de linearidade o cristianismo pois o nascimento, a morte e ressurreição de Cristo são acontecimentos únicos e não se repetem e o apocalipse fechará esse ciclo temporal.

Herança do latim, o termo tempus evoluiu para tempo no português e ditongou no espanhol resultando tiempo. Se formos consultar nos dicionários, nos deparamos com múltiplos significados para um termo tão polissêmico como esse, conforme o âmbito do saber no qual é usado, seja física, música, astronomia... além das numerosas expressões das 
quais forma parte a palavra tempo. O dicionário, usado no presente trabalho com o intuito de exemplificar as várias acepções do termo, considerado como texto de consulta para a qual não são precisos conhecimentos específicos, é aquele que reúne o significado que uma cultura dá a um determinado termo. O dicionário, exemplo de um saber enciclopédico, é a ponte entre os sentidos que o termo possui nas diferentes áreas de saber e, o que de uma forma corriqueira, é entendido como tempo quando falamos, por exemplo, com um significado meteorológico, gosto do bom tempo (dependendo da cultura pode ser sol, chuva, frio), ou ao dizer como passa o tempo, com o sentido de sucessão de minutos, horas, dias, semanas, meses, anos e o valor subjetivo que pode adquirir, a lentidão de quem sofre ou a fugacidade da felicidade.

A continuação apresentam-se os significados que o dicionário Aurélio da língua portuguesa dá ao vocábulo tempo:

[Do latim tempus, pela f. tempos, que foi sentida como um plural em português de que se tiraria um singular.] $\boldsymbol{s} . \boldsymbol{m}$.

1. A sucessão dos anos, dos dias, das horas, etc., que envolve, para o homem, a noção de presente, passado e futuro: o curso do tempo; $O$ tempo é um meio contínuo e indefinido no qual os acontecimentos parecem suceder-se em momentos irreversíveis; "O tempo... horas de horror e de tédio da memória..." (Manuel Bandeira, Estrela da Vida Enteira, p. 41).

2. Momento u ocasião apropriada (ou disponível) para que uma coisa se realize: Não tive tempo para ler os jornais; Ainda é tempo de reconsiderar a sua decisão.

3. Época (3): O que se usava nesse tempo, como tratamento de respeito mais comum, ainda mesmo entre namorados de menor intimidade era senhor e senhora." (Miecio Tati, O mundo de Machado de Assis, p.134).

4. As condições meteorológicas: O tempo esta bom.

5. Estação, quadra: O tempo da colheita, o tempo da estiagem. 
6. Certo período, visto do ângulo daquele que fala ou de quem se fala; época: No meu tempo o colégio tinha poucos alunos; isso não é do teu tempo.

7. O período em que se vive; época; século: É homem do seu tempo.

8. E. ling. Cada um dos conjuntos de formas flexionadas em que subdivide a conjugação de um verbo. [Embora tenha como princípio organizador a localização de uma situação em relação ao momento da fala pode também traduzir aspecto(8) ou modo(9) como se depreende de termos da Nomenclatura Gramatical Brasileira: pretérito (indicação de tempo) perfeito (indicação de aspecto).

9. E. Ling. A expressão gramatical da noção de tempo.

10. E. Ling. Período de tempo durante o qual uma unidade de fala é pronunciada.

11. Esport. Cada um dos períodos em que se dividem certas partidas: $O s$ jogos de futebol compreendem, em regra, dois tempos.

12. Fís. Coordenada, que juntamente com as coordenadas espaciais, é necessária para localizar univocamente uma ocorrência física.

13. Mús. cada uma das partes, em andamentos diferentes, em que se dividem certas peças.

Segundo o Diccionario de la Real Academia Española o vocábulo tiempo é definido nos seguintes termos:

(Del lat. tempus.) $\mathrm{m}$.

1. Duración de las cosas sujetas a mudanza.

2. Parte de esa duración.

3. Época durante la cual vive alguna persona o sucede alguna cosa. En TIEMPO de Trajano; en TIEMPO del descubrimiento de América.

4. Estación del año.

5. Edad.

6. Edad de las cosas desde que empezaron a existir. 
7. Oportunidad, ocasión o coyuntura de hacer algo. A su TIEMPO; ahora no es TIEMPO.

8. Lugar, proporción o espacio libre de otros negocios. No tengo TIEMPO.

9. Largo espacio de tiempo. TIEMPO ha que no nos vemos.

10. Cada uno de los actos sucesivos en los que se divide la ejecución de una cosa; como ciertos ejercicios militares, las composiciones musicales, etc.

11. Estado atmosférico. Hace buen TIEMPO.

\section{V. fruta del tiempo.}

\section{V. unidad de tiempo.}

\section{V. bomba de tiempo.}

15. fam. V. corrida de tiempo.

\section{Astron. V. ecuación de tiempo.}

17. Esgri. Golpe que a pie firme ejecuta el tirador para llegar a tocar al adversario.

18. Gram. Cada una de las varias divisiones de la conjugación correspondientes a la época relativa en que se ejecuta o sucede la acción del verbo.

19. Mar. Temporal o tempestad duradera en el mar. Correr un TIEMPO; aguantar un TIEMPO.

20. Mec. Fase de um motor.

21. Mús. Cada compás.

A primeira acepção que o dicionário Aurélio recolhe define o tempo como:

- a sucessão dos anos, dos dias, das horas, etc., que envolve, para o homem a noção de presente, passado e futuro.

Já o Diccionario de la Lengua Española da Real Academia Española, define o tempo como:

- duración de las cosas sujetas a mudanzas.

Cada uma com suas sutilezas, ambas definições complementam-se, moldando o perfil do antigo deus Cronos. 
Entre as várias definições do vocábulo tempo merecem especial atenção para o presente trabalho aquelas que no Aurélio consideram-se no âmbito da lingüística e o Diccionario da la Lengua Española no da gramática:

- cada um dos conjuntos de formas flexionadas em que se subdivide a conjugação de um verbo - explica o dicionário brasileiro;

- cada una de las varias divisiones de la conjugación correspondientes a la época relativa en que se ejecuta o sucede la acción del verbo define o dicionário espanhol.

Ao observar estas definições considera-se que existe um tempo que não é aquele tempo do ser humano, ou seja as palavras que designam o tempo não são o tempo propriamente dito. A língua como sistema de signos, reserva a determinado grupo de signos lingüísticos a expressão do tempo, sendo assim que o verbo é a categoria de palavras por excelência, mas não a única, que é utilizada para expressar o tempo.

Apurando um pouco mais as definições dos dicionários, diferenciam-se dois tipos:

- aquelas que se referem ao tempo desde um ponto de vista classificatório, como uma categoria de palavras:

- tempo composto: o que se conjuga com um verbo auxiliar: tenho dito;

- tempo simples: o que se conjuga sem um verbo auxiliar.

- aquelas outras definições que localizam o tempo no discurso, como:

- tempo absoluto: tempo que localiza uma situação em relação ao momento da fala (presente, passado, futuro);

- tempo relativo: tempo que localiza uma situação em relação a um ponto de referência estabelecido no discurso, e que não é necessariamente, o presente da enunciação.

Benveniste (Benveniste, 1989, p. 78) faz uma clara distinção entre esses três tempos, que segundo os dicionários existem: 
O tempo físico, é o tempo do mundo, do universo, infinito e linear, variável segundo cada ser humano, sua vivencia e suas emoções, o tempo que as vezes não passa ou aquele que transcorre rápido demais.

O tempo crônico, em que os acontecimentos dispõem-se um após outro, em uma continuidade, caracterizando-se por: uma condição estativa, ou seja, um ponto zero, um acontecimento muito importante a partir do qual se começa a contar, uma segunda condição diretiva, que enuncia o anterior e o posterior, e, finalmente, uma condição mensurativa, que mede o tempo em unidades como dias, meses etc.

Por último, o tempo lingüístico, aquele que realiza o tempo dos homens instaurando-o em um discurso, levando em consideração o momento da fala como o ponto de referência para situar os acontecimentos.

\subsection{Tempo e discurso}

Com anterioridade a Benveniste, Ferdinand de Saussure, no seu Curso de lingüística geral, já em 1916, fez algumas afirmações que mudariam o rumo da lingüística. A lingüística que precede a Saussure entendia que uma palavra era o objeto que ela representava, que a palavra livro e o objeto livro tinham uma relação direta, que as palavras serviam para referirmos às coisas que existem no mundo. Entendia-se a língua como uma nomenclatura.

Nessa concepção de língua o tempo aparecia sempre representado numa linha na qual o pretérito era o momento anterior ao presente que, por sua vez, era o precursor do futuro. O tempo lingüístico pretendia ser um calco do tempo do mundo e mais especificamente do tempo do homem. Pois se o tempo do homem é linear e uma coisa acontece após outra, o tempo lingüístico também deveria ser assim.

Passado Presente $\quad$ Futuro


Saussure afirma que a língua não se define pela relação da coisa com a palavra e sim pela relação que estabelecem uma imagem acústica, o significante, e um conceito, o significado. Assim a língua deixará de ser usada como nomenclatura, para ser entendida como princípio classificatório, isto é, não será mais entendida como a relação entre as palavras e as coisas. A relação entre uma imagem acústica, significante, e um conceito, significado, constituem o signo lingüístico e tal relação é arbitrária (Saussure, 1999: 28), isto é, não existe uma relação de causa e efeito para que determinado significante seja atribuído a um significado concreto. O signo lingüístico é definido dentro de um sistema, isso significa que ele adquire valor na relação com outros signos do sistema. Pietroforte (2002: 85), de acordo com Saussure, explica que se existe um mundo repleto de coisas e cabe a língua simplesmente nomeá-las então á língua é só um reflexo das coisas, não tem um domínio próprio, pois baixo esse ponto de vista é só uma coleção de nomes. No entanto, na perspectiva saussuriana como o signo ganha valor na relação com outros signos dentro do sistema, esse conceito traz a significação para dentro da língua e sua estrutura. A significação se depreende não da relação entre as palavras e as coisas e sim dos signos em suas relações com outros signos. Se os signos significam dentro de um sistema de signos quer dizer que esse sistema compreende uma visão de mundo (Pietroforte, 2002: 86), ou seja um princípio de classificação que se projetando sobre as coisas do mundo, classifica-as de acordo com sua estrutura interna. São os signos os que classificam as coisas do mundo e não o mundo quem estabelece uma classificação dos signos, das palavras. Um significado, um conceito, é uma idéia que representa uma forma determinada de ver o mundo. Esse significado precisa de um significante, de uma imagem acústica, para ser expresso. Essa relação significante-significado varia de uma língua para outra pois representam diferentes visões de mundo. A língua, por tanto, apresenta-se como a estrutura, a forma, que será concretizada por um falante em suas manifestações individuais e momentâneas, já que nada existe de coletivo na fala. O mistério é descobrir como se concretiza a língua na fala.

Segundo Fiorin, uma das limitações que apresenta a proposta saussuriana, no que concerne a relação língual fala, é não perceber a existência de leis de organização do discurso, ao afirmar que a fala é o reino da liberdade e da criação (Fiorin, 2001: 29). Estamos diante de uma lingüística preponderantemente do enunciado (Fiorin, 2001: 30), 
produto da enunciação, que considera a enunciação, processo de significação que garante o sentido assumido pelos signos, como um acontecimento único, realizado por sujeitos particulares numa situação particular, e, assim, não é possível reconhecê-la como sistema. Isto é, se a fala fosse considerada um ato único não seria possível estabelecer leis que sistematizassem a enunciação. Posteriormente, com Benveniste e Jakobson, se reconhece na enunciação a existência de um sistema invariável, sob a multiplicidade infinita dos atos particulares de enunciação.

Ainda segundo Fiorin, de acordo com Greimas, o processo de geração de sentido realiza-se por meio do percurso gerativo. A semiótica concebe o plano do conteúdo do texto sob a forma de um percurso gerativo do sentido. Esse percurso gerativo consta de três níveis que vão desde o mais simples e abstrato até o mais complexo e concreto:

O nível mais abstrato recebe o nome de nível fundamental, em ele o significado depreende-se como uma oposição mínima de sentido. O nível fundamental é a instância inicial do percurso gerativo do sentido em que se estabelece a rede de relações básicas que geram o sentido. É o patamar do percurso que procura explicar os níveis mais abstratos da produção, do funcionamento e da interpretação do discurso. Consta de uma sintaxe, descrita pelo quadrado semiótico e suas articulações, e uma semântica, descrita pelas categorias semânticas que geram os valores e as relações tímico-fóricas.

O segundo é o nível narrativo: a organização narrativa descreve e explica as relações e as funções do simulacro do ser humano transformando o mundo, assim como determina quem são os seus participantes. Assim a narratividade resulta, por uma parte, do fazer de um sujeito que age no ou sobre o mundo em busca de valores investidos em objetos transformando determinados estados. Por outra, a narratividade resulta da busca de valores, do estabelecimento e/ou ruptura de contratos entre um destinador e um destinatário. No nível narrativo, a sintaxe é descrita pelo esquema narrativo, e a semântica, pelos valores modais e descritivos do objeto, por meio dos quais o sujeito se define em relações juntivas, de conjunção ou de disjunção. 
E, finalmente, o nível discursivo, é aquele em que o sujeito da enunciação assume a narrativa. O nível discursivo é o patamar em que as formas abstratas do nível narrativo são revestidas de termos que lhe dão concretude. O nível discursivo produz as variações de conteúdos narrativos invariantes ${ }^{1}$. As estruturas discursivas é o lugar onde se revela a enunciação e se manifestam os valores que sustentam o texto. A enunciação realiza a tarefa mediadora entre as estruturas narrativas e as discursivas, o sujeito da enunciação assume os esquemas narrativos e os converte em discurso deixando marcas nele. A enunciação é o ato de produção do discurso, é uma instancia pressuposta pelo enunciado (produto da enunciação $)^{2}$. Ao analisar a semântica e a sintaxe do discurso é possível recuperar e reconstruir a instância da enunciação, que existe sempre pressuposta.

A sintaxe do discurso abrange tanto as projeções da enunciação no enunciado como as relações entre o enunciador e o enunciatário. Tais aspectos não podem ser entendidos separadamente, pois ambos são utilizados pelo enunciador para levar o enunciatário a crer e fazer.

Em relação às projeções da enunciação no enunciado deve-se dizer que a enunciação é a instância que produz o discurso e, ao mesmo tempo, instaura o sujeito da enunciação, projetando para fora de si os atores do discurso e suas coordenadas espaçotemporais. A operação por meio da qual a enunciação realiza tal projeção denomina-se desembreagem ou debreagem. Há três tipos de desembreagens: a de pessoa (actancial), a de espaço (espacial) e a de tempo (temporal). Quando no enunciado estão projetados uma pessoa eu/tu, um tempo agora e um espaço aqui, ocorre uma desembreagem enunciativa. Quando no enunciado estão projetados uma pessoa ele, um tempo então e um espaço lá, ocorre uma desembreagem enunciva. Dessas diferentes desembreagens surgem a enunciação-enunciada, no primeiro caso, e o enunciado (enunciado enunciado), propriamente dito, no segundo caso. Na enunciação enunciada, o sujeito que se diz eu é denominado narrador e o $t u$, instalado por ele, narratário. Os discursos em primeira pessoa são considerados "subjetivos". Já o enunciado, propriamente dito, caracteriza os discursos em terceira pessoa considerados como "objetivos".

\footnotetext{
${ }^{1}$ FIORIN, José Luiz (2001). Elementos de análise do discurso. São Paulo: Contexto. (p.29).

${ }^{2}$ FIORIN, José Luiz (2001). Elementos de análise do discurso. São Paulo: Contexto. (p. 39).
} 
Além dos tipos de desembreagens estudados, o enunciador pode operar desembreagens internas, ou seja, de $2^{\circ}$ grau, ao dar a palavra a uma das pessoas do enunciado ou da enunciação instaurada no enunciado. Os simulacros de diálogos nos textos são responsabilidade das desembreagens internas, já que estabelecem interlocutores, ao dar voz a atores no discurso. A desembreagem de $2^{\circ}$ grau cria o discurso direto, unidade discursiva que produz um efeito de sentido de verdade.

Já no que diz a respeito das relações entre enunciador e enunciatário, o sujeito da enunciação desdobra-se em enunciador e enunciatário que cumprem os papéis actanciais de destinador e destinatário do objeto-discurso. Assim o enunciador resulta ser o destinador manipulador responsável pelos valores do discurso e quem leva o enunciatário, ou seja, o destinatário, a crer e a fazer. O discurso transforma o fazer manipulador em fazer persuasivo. O destinatário passa a cumprir o papel de destinatário-sujeito, mesmo que o fazer pretendido pelo enunciador não seja realizado. $\mathrm{O}$ fazer persuasivo do enunciador tem a sua resposta no fazer interpretativo do enunciatário, que também ocorre no discurso enunciado.

A verdade ou a falsidade do discurso depende da cultura, da sociedade, do próprio discurso, pois o que é válido para uma sociedade ou para uma cultura pode não o ser para outras. É possível dizer que o enunciador propõe um contrato que determina como o enunciatário deve interpretar a verdade do discurso e que, em segundo lugar, o dizerverdadeiro tem a ver com anteriores contratos de veridicção, com o sistema de valores próprio de uma sociedade ou de uma cultura.

Na semântica discursiva, os esquemas narrativos abstratos podem-se revestir com temas e figuras para assim concretizar o sentido. A semântica discursiva explica e descreve o passo dos percursos narrativos para percursos discursivos. O sujeito da enunciação é quem provê o discurso de temas e figuras dando coerência semântica, criando efeitos de realidade e estabelecendo relação entre o mundo e o discurso.

O percurso gerativo de sentido, portanto, se refere ao plano do conteúdo, mas o conteúdo precisa de uma expressão, e da união de ambos planos surge um texto. O discurso 
é parte do plano do conteúdo, e a enunciação é o ato de produção do discurso. Quando assume os esquemas narrativos, o sujeito da enunciação os torna discurso. No ato de produção de discurso, a enunciação deixa suas marcas nele, marcas de pessoa, tempo e espaço. A enunciação é a instância do eu-aqui-agora, já que o sujeito da enunciação é um $e u$ que realiza a produção do discurso num espaço que é o aqui e num tempo que é o agora. A sintaxe do discurso, ao estudar as marcas da enunciação no enunciado, analisa três procedimentos de discursivização: a actorialização, a espacialização e a temporalização (Fiorin, 2001: 40).

Ao falar concretamente da temporalização, lembre-se a distinção entre o tempo humano, quando acontecem as mudanças em relação ao anterior e ao posterior, a história, a própria vida, e o tempo específico da língua. Nas palavras de Benveniste:

O que o tempo lingüístico tem de singular é o fato de estar organicamente ligado ao exercício da fala, o fato de se definir e se organizar como função do discurso.

Esse tempo tem seu centro - um centro, ao mesmo tempo, gerador e axial no presente da instância da fala (Benveniste, 1989: 74).

O discurso vem marcado por um agora, que é o instante da enunciação. Em contraposição ao agora, cria-se um então. As oposições temporais vão se fundamentar nesse agora, momento da enunciação. O agora é gerado por um ato de linguagem, e cria um eixo que ordena a categoria concomitância vs não-concomitância, que, por sua vez, articula-se em anterioridade vs posterioridade. Isto é, o momento que indica a simultaneidade, concomitância, entre a narração e o narrado permanece ao longo do discurso, e a partir dessa coincidência criam-se duas não-coincidências: a anterioridade do acontecimento em relação ao discurso, aquilo que vai ser evocado pela memória, e a posterioridade, ou seja, aquilo que ainda não aconteceu. A anterioridade e a posterioridade estão em função do momento da enunciação, o eixo ordenador do tempo. Todas as línguas dão testemunho desta relação, mas cada uma delas à sua maneira particular, estruturando os sistemas lingüísticos e sua organização formal. 
Momento da Enunciação

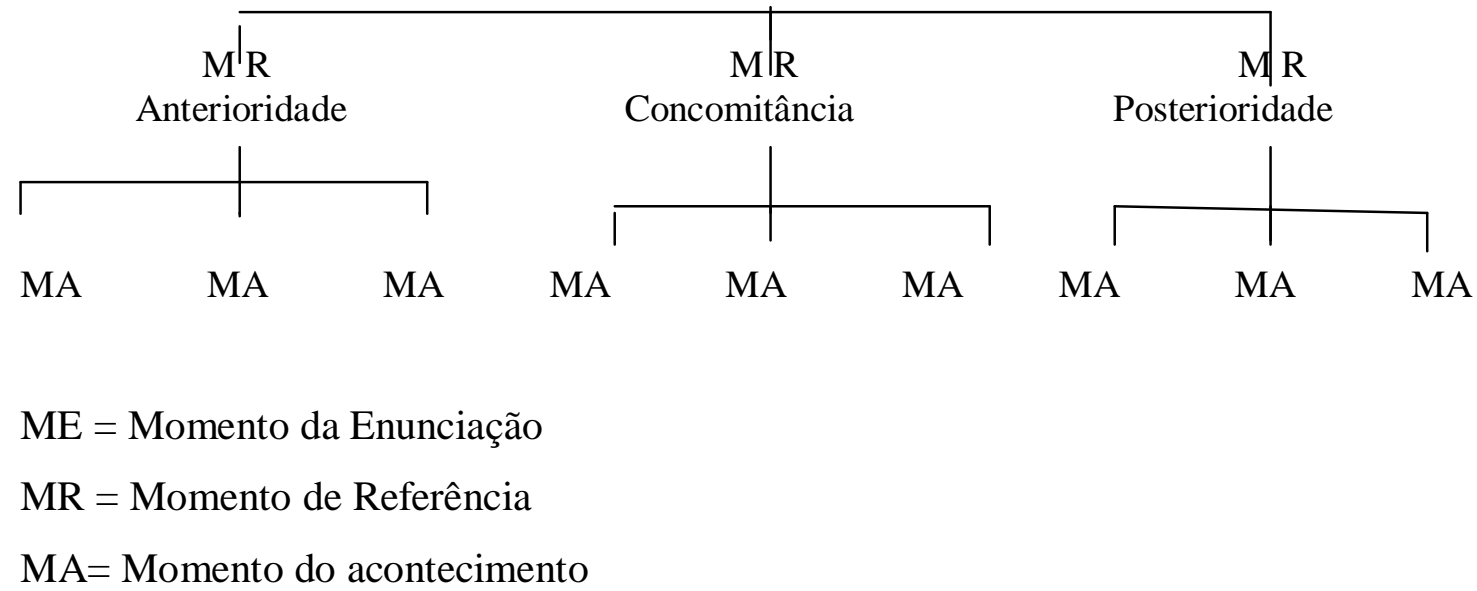

Foi deixada para trás a linha temporal para ser substituída por um esquema que partiendo do momento da enunciação desdobra-se em vários outros: momento de referência (anterior, concomitante e posterior ao momento da enunciação) que por sua vez desdobramse em vários momentos do acontecimento que expressam a mesma relação de concomitância vs não-concomitância (anterioridade, posterioridade) atendendo aos princípios saussurianos de que a língua não é uma nomenclatura e sim um sistema de signos e o significado se depreende da relação deles. Aplicado ao tempo verbal vem dizer que o significado dos tempos está no valor adquirido na relação de uns com os outros tomando como ponto de partida o momento da enunciação.

Nesse marco teórico proposto por Fiorin (Fiorin 2000), visa-se estudar como essa relação de anterioridade, posterioridade e concomitância acontece no español, a maneira particular como essa língua estrutura o sistema do tempo. Assim, pretende-se esclarecer o uso e o significado dos tempos verbais no espanhol. O modelo de esquema proposto por Fiorin (Fiorin, 2000) constitui a base da pesquisa, sem depreciar os trabalhos de estudiosos 
da envergadura de Andrés Bello, entre outros, quem já em sua Gramática de la Lengua Catellana publicada no Chile em 1847, ao explicar o "significado fundamental de los tiempos simples del indicativo" (Bello, 2004: 200) ordena o sistema verbal no que diz respeito à coexistência do atributo com o momento em que o verbo é proferido, ou à coexistência do atributo com uma coisa passada, ou da posterioridade do atributo em relação a uma coisa pretérita, ou a anterioridade do atributo ao ato da fala, etc. numa tentativa de organização do sistema verbal em um modelo que fuja da linearidade cronológica. Muito longe de ser esquecido, Andrés Bello é reconhecido, comentado e ampliado em gramáticas posteriores, e são abundantes as menções de Emilio Alarcos ou as que aparecem no Esbozo de la Nueva Gramática de la Lengua Española, ou mesmo as contidas na parte dedicada ao verbo na Gramática Descriptiva da Real Academia Española.

\subsection{Passado e presente do espanhol}

Por primera vez el Imperio no crea la lengua. Es la lengua del Imperio la que cede a la presión migratoria, que va a transformar este país.

Juan Luis Cebrián ${ }^{3}$

\section{a) Aspectos diacrônicos}

Quando os romanos invadiram a península Ibérica no século II a.C., impuseram a língua latina, para a sua difusão não foram precisas coações, foi suficiente o peso das circunstancias: caráter de idioma oficial, ação da escola e do serviço militar, superioridade

\footnotetext{
${ }^{3}$ EL PAÍ́S - Cultura - 14-04-2006.
} 
cultural y conveniência de empregar um instrumento expressivo comum ao Império (Lapesa, 1986: 56). Pouco a pouco as primitivas línguas peninsulares foram desaparecendo, os nativos começaram a se comunicar em latim e posteriormente as línguas pre-romances foram ficando no âmbito familiar até desaparecerem.

Com a decadência do Império no século V, o latim vulgar, sem a estabilidade política e a contenção que supunha a língua clássica, aprofundou as suas diferenças nas várias províncias bárbaras. Na península Ibérica evoluíram, filhos do latim, o gallego, o catalán e o castellano, que junto com o vasco, que convivera com o latim, proporcionaram um panorama lingüístico próprio. Mesmo com as posteriores invasões dos povos bárbaros, alanos, vândalos, visigodos, a evolução das línguas romances seguiu seu próprio curso.

A invasão árabe no 711 d.C. deixou um legado cultural de inestimável valor e o castellano ficou impregnado de um vocabulário que abrangia os mais variados âmbitos do saber. Nesses séculos de convívio da cultura árabe, judaica e cristã, o castellano foi se consolidando como língua romance, mostra desse convívio são os primeiros textos conservados em que o castellano é usado com fins literários. Apareceu um gênero lírico a moaxaja, que junto do texto principal escrito em árabe ou em hebraico inseria palavras em castellano, especialmente no final da composição, na jarcha. Enquanto na Espanha muçulmana apareciam esse tipo de canções líricas, na Espanha cristã era a vez do primeiro cantar épico, o Cantar de Mio Cid.

O castellano cresceu como língua utilizada para fins didáticos com Alfonso X el Sábio, e assim transitou o castellano medieval para o clássico. No século XV, o processo de unificação da língua coincide com grandes empresas nacionais, Antonio de Nebrija publicava em 1492 a Gramática do castellano, alguns messes depois da partida das naus de Colombo para América e o final da Reconquista com a rendição de Granada, o último reduto árabe.

Na América os espanhóis contavam com várias vantagens, eles levavam um idioma unificado frente ao labirinto das línguas pré-colombinas, com notável cultivo escrito em diversas matérias, filho do latim e com alfabeto próprio. Difundiu-se modestamente sem 
muita demora graças à imprensa (LODARES, 2001, p.20). Más o que fora verdadeiramente importante para a difusão da língua, foram os cavalos que se trasladavam por terra e os barcos que recorriam grandes distancias, assim em pouco tempo o español adquiriu uma extensão que nenhuma língua ameríndia até então conhecera. Um sistema revolucionário de produção, comercio, transporte e comunicação, nunca visto naquelas terras, desenvolveu-se em espanhol. Apesar disso era uma minoria a que falava espanhol nos primórdios da colonização, os conquistadores, foram militares ou religiosos, acharam mais conveniente aproxima-se do índio fazendo uso de sinais, de tradutores e até aprendendo as línguas indígenas. Paradoxalmente, foi a independência das terras americanas da metrópole a que consolidou a língua espanhola no novo continente. Os independentistas seguidores das idéias do Iluminismo, acharam na instrução pública uma forma de consolidar os recentes estados. O espanhol, até então falado por uma minoria passou a ser a língua dos novos estados, das relações comerciais, das leis, das letras e da cultura.

Na velha Espanha, a fixação do idioma evoluira consideravelmente nos Siglos de oro, da mão de grandes autores como Cervantes, Góngora, Quevedo, Lope de Vega, entre outros, embora os preceitos gramaticais não estivessem regulamentados. No século XVIII, a atitude reflexiva dos homens cultos prioriza a idéia de correção gramatical (Lapesa, 1986: 419) símbolo dessa atitude é a criação da Real Academia Española (1713) e a publicação do Diccionario de Autoridades (1726-39). No século XIX, criaram-se as Academias americanas, a última delas no 1973 nos Estados Unidos, totalizando na atualidade vinte e duas.

Até o século XIX existia, tanto entre os europeus quanto entre os americanos, o preconceito de que os usos de América, assim que se apartavam dos da Espanha, eram uma espécie de usos corruptos. Foi Rufino Jose Cuervo, um dos fundadores da Academia Colombiana (1871), cujas declarações, na época, foram reveladoras, quem apontou que muitos desses usos eram formas clássicas do espanhol peninsular que a Espanha tinha esquecido e que América conservava, demonstrando assim que os usos da América eram tão válidos quanto os da Espanha, colocando no mesmo patamar de igualdade o espanhol falado na América e na Espanha. Finalmente, no começo do século XIX, foi reconhecido esse fato evidente e, conseqüentemente, foi abandonado o conceito de pureza idiomática, 
identificado com o castellano, abrindo espaço para o de norma hispânica ideal, pelo menos na escritura a norma panhispánica não admitia dúvidas (Lodares, 2001:138-139).

Com o passar do tempo a literatura hispano-americana confirmou que o espanhol de América estava, efetivamente, no mesmo patamar que o da Espanha. Borges, Cortazar, Otavio Paz, Gabriel Garcia Márquez, Pablo Neruda, entre muitos outros, levaram o espanhol escrito a altos níveis de preciosismo.

\section{b) Aspectos sincrônicos}

Atualmente, o espanhol é a terceira língua mas falada no mundo, depois do chinês mandarim e do inglês, com quase 400 milhões de falantes repartidos em uma vintena de países.

Pela extensão do seu território aparece no quarto lugar, depois do inglês, francês e russo. Em milhares de quilômetros o espanhol ocupa o 8,9 \% da superfície emergida da terra. Estamos diante da língua romance mais difundida, à frente do francês e do português, com falantes repartidos pelos cinco continentes, embora concentrados significativamente no continente americano.

Deve-se levar em consideração a população dos Estados Unidos falante de espanhol, pois representa o $20 \%$, com mais de trinta milhões de usuários. Historicamente os territórios de México, algumas partes da Califórnia, Texas, Arizona, pertenceram à coroa espanhola. A tal fato deve somar-se o continuo fluxo de migração hispana, procedente dos diferentes países americanos, desde a segunda metade do século XX.

Hoje é língua oficial das Nações Unidas e outros organismos internacionais, ocupa o sétimo lugar em número de obras traduzidas para outras línguas e na rede ocupa o segundo lugar depois do inglês. 
Seguidamente apresentam-se alguns dados sobre o uso e difusão do espanhol no mundo ${ }^{4}$.

\begin{tabular}{|c|c|c|c|}
\hline \multicolumn{4}{|c|}{ Usuários de espanhol em países nos quais é língua oficial } \\
\hline & $\begin{array}{l}\text { Número de } \\
\text { falantes }\end{array}$ & População & $\begin{array}{c}\text { Falantes \% } \\
\text { população }\end{array}$ \\
\hline Argentina & $35,300,000$ & $35,409,000$ & 99.7 \\
\hline Bolívia & $6,810,000$ & $7,767,000$ & 87.7 \\
\hline Chile & $13,080,000$ & $14,583,000$ & 89.7 \\
\hline Colômbia & $35,850,000$ & $36,200,000$ & 99.0 \\
\hline Costa Rica & $3,382,000$ & $3,468,000$ & 97.5 \\
\hline Cuba & $11,190,000$ & $11,190,000$ & 100.0 \\
\hline Equador & $11,100,000$ & $11,937,000$ & 93.0 \\
\hline El Salvador & $5,662,000$ & $5,662,000$ & 100.0 \\
\hline Espanha & $38,969,000$ & $39,323,000$ & 99.1 \\
\hline Guatemala & $7,270,000$ & $11,242,000$ & 64.7 \\
\hline Guinea Equatorial & 443,000 & 443,000 & 100.0 \\
\hline Honduras & $5,718,000$ & $5,823,000$ & 98.2 \\
\hline México & $97,490,000$ & $94,275,000$ & 98.5 \\
\hline Nicarágua & $4,112,000$ & $4,632,000$ & 87.4 \\
\hline Panamá & $2,088,000$ & $2,719,000$ & 76.8 \\
\hline
\end{tabular}

${ }^{4}$ Os dados apresentados foram extraídos de:

www.espanolsinfronteras.com, www.cgcnet.org/nuestroidioma/hemeroteca, www.cvc.es . 


\begin{tabular}{|c|c||c||c|}
\hline Paraguai & $2,805,000$ & $5,089,000$ & 55.1 \\
\hline Peru & $19,440,000$ & $24,371,000$ & 79.8 \\
\hline Porto Rico & $3,741,000$ & $3,809,000$ & 98.2 \\
\hline Rep. Dominicana & $7,650,000$ & $7,802,000$ & 98.1 \\
\hline Uruguai & $3,050,000$ & $3,185,000$ & 95.8 \\
\hline Venezuela & $22,060,000$ & $22,777,000$ & 96.9 \\
\hline Total & $332,610,000$ & $351,706,000$ & 94.6 \\
\hline
\end{tabular}

\begin{tabular}{|c|c|}
\hline \multicolumn{2}{|c|}{ Usuários de espanhol em países nos quais NÃO é língua oficial } \\
\hline País & Número de falantes \\
\hline Alemanha & 140,000 (em 1997) \\
\hline Andorra & 30,000 \\
\hline Antillas holandesas (Bonaire y Curazao) & 189,602 \\
\hline Aruba & 6,000 \\
\hline Austrália & 97,000 \\
\hline Bélgica & 50,000 \\
\hline Belize & 130,000 \\
\hline Brasil & 43,901 \\
\hline Canadá & 177,425 \\
\hline \hline Estados Unidos & $38,800,000$ (ano 2004) \\
\hline Francia & 220,000 \\
\hline Filipinas & $1,816,389$ (em 1997) \\
\hline Gibraltar & 10,061 \\
\hline \hline
\end{tabular}




\begin{tabular}{|c||c|}
\hline \multicolumn{1}{|c||}{ Guam } & 793 \\
\hline \hline Israel & $50,000 \quad(\mathrm{em} \mathrm{1997)}$ \\
\hline \hline Luxemburgo & 3,000 \\
\hline \hline Marrocos & 20,000 \\
\hline \hline Saara Ocidental & $16,648(\mathrm{em} \mathrm{1970)}$ \\
\hline \hline Suécia & 56,000 \\
\hline \hline Turquia & 23,175 \\
\hline \hline Ilhas Virgens & 13,000 \\
\hline \hline Suíça & 123,708 \\
\hline \hline
\end{tabular}

\section{c) Que español estudar}

A abordagem do estudo do español $l^{5}$ deve reconhecer a unidade e ao mesmo tempo a diversidade desta língua, falada e escrita em vários continentes, seja como língua oficial, seja como primeira língua em países nos quais não existe essa oficialidade. Francisco Moreno (2000: 15) cita o Anuario del Instituto Cervantes de 1988 para apresentar uma visão geral da situação da língua no mundo, em que seus rasgos principais mantêm-se vigentes. O Anuário explica as características da língua espanhola, resumidas nos seguintes pontos:

1. O español é um idioma homogêneo, com caráter de coiné, com um importante grau de nivelação e baixo risco de fragmentação. Um sistema vocálico simples (cinco vogais) e um sistema consonântico (17 consoantes) comum para todos os hispanofalantes,

\footnotetext{
${ }^{5} \mathrm{O}$ título deste apartado faz referência direta ao livro de Francisco Moreno Fernández (ver bibliografia) que será usado para delimitar o objeto de estudo do presente trabalho.
} 
junto de um léxico geral e uma sintaxe de variação moderada, especialmente no uso culto, providenciam homogeneidade à língua. As variedades internas da língua não representam incompatibilidade com o fato de ser uma língua homogênea, pois são variedades que surgem em distintas áreas geográficas e em diferentes grupos sociais.

2. O español é uma língua de cultura, existem grandes nomes da literatura espanhola ou hispano-americana, reconhecidos internacionalmente, instrumento de transmissão de cultura e pensamento.

3. O español é uma língua internacional, língua oficial, ou co-oficial, nos países da América do Sul (exceto Brasil), América Central e México e nos assentamentos do Saara ${ }^{6}$. É língua oficial na ONU assim como em muitas outras organizações internacionais e uma das três línguas de comunicação internacional junto ao inglês e o francês.

4. O español é uma língua geograficamente compacta pois a maioria dos países hispanofalantes ocupa territórios contíguos.

5. O español é uma língua em expansão. O seu crescimento foi constante desde a Idade Média, embora o século XX seja a época de maior crescimento.

6. O domínio hispanofalante apresenta um índice de comunicatividade muito alto e um índice de diversidade muito baixo. Significa que o español é veículo de comunicação em comunidades plurilíngües. Nos territórios em que é língua oficial, para 95\% dos falantes é a língua materna.

A unidade lingüística do español é um fato consumado, segundo a explicação apresentada anteriormente, mas nem por isso deve ser esquecida a diversidade que conforma tal língua. Espanha e América compartilham, além dos traços do que poderia ser chamado de español general, a maioria dos fatos lingüísticos que se manifestam como variáveis (Moreno, 2000: 35). Essas ocorrências, que acontecem especialmente no âmbito da variação fonético-fonológica e no da gramática, normalmente estão presentes em ambos os lados do Atlântico. Exemplo disso é o seseo, fenômeno que acontece tanto em Andalucia como em América; o uso de ustedes para a segunda pessoa, ocorrência habitual em Canarias e algumas regiões de Andalucia assim como em América; o uso generalizado do pretérito perfecto simple com valor tanto de pretérito como de antepresente tanto em

\footnotetext{
${ }^{6}$ Ver tabelas a respeito deste assunto.
} 
América como em regiões do norte peninsular, Galicia e Asturias, entre outros exemplos. Já no léxico existem usos não coincidentes, seja estabelecendo a comparação entre os usos americanos e os espanhóis, seja nos usos do território americanos, seja nos usos peninsulares e canários. A falta de uniformidade lingüística, seja em Espanha seja em América ou entre ambas, é um fato que evidencia riqueza e variedade internas que não alcançam o nível da divergência como pode acontecer em outras línguas.

A distribuição em zonas do espanhol no mundo mais clara e geral é aquela que separa áreas conservadoras de áreas inovadoras. $O$ que não significa que umas correspondam a Espanha e outras a América, e sim que convivem ambas as zonas tanto em Espanha quanto em América. Desde esse ponto de vista, Moreno (2000: 38) diferencia várias áreas gerais representadas pelos usos lingüísticos urbanos dos territórios mais influentes:

A.1. Área caribenha, representada pelos usos de San Juan de Puerto Rico, La Habana ou Santo Domingo.

A.2. Área mexicana ou centroamericana, representada pelos usos de México D.F. e de outras cidades e territórios significativos.

A.3. Área andina, representada pelos usos de Bogotá, La Paz ou Lima.

A.4. Área rio-platense ou do Chaco, representada pelos usos de Buenos Aires, Montevidéu e Assunção.

A.5. Área chilena, representada pelos usos de Santiago.

E.1. Área castellana, representada pelos usos de cidades como Madri ou Burgos.

E.2. Área andaluza, representada pelos usos de cidades como Sevilha, Málaga ou Granada.

E.3. Área canária, representada pelos usos de cidades como Las Palmas ou Santa Cruz de Tenerife.

A variabilidade lingüística remete não só às diferenças apreciáveis entre as várias regiões. Devem-se considerar também as de natureza social. Assim pode-se falar em sociolecto como o conjunto de traços lingüísticos que caracterizam um grupo social. Habitualmente esta terminologia é reservada para aquelas características que aparecem em 
um estrato social determinado, ou seja o socilecto, que vem relacionado com classe social. Portanto, os socilectos altos são aqueles que dão forma à língua culta, constituída pelos traços que caracterizam a língua das pessoas mais instruídas, com uma formação melhor e com mais prestígio social. E, conseqüentemente, os sociolectos bajos são aqueles que dão forma à língua popular, um nível complementário das formas cultas, manifestados principalmente nas classes sociais média e baixa. A língua popular não deve ser confundida com a vulgar, pois a primeira esta dentro do correto, do admitido ou consentido, e a segunda não.

Diante dessa visão geral, entre a unidade e a diversidade do español, a tendência geral é a busca de um modelo de língua que possa ser ensinado, aprendido e, no caso concreto deste trabalho, estudado. Ao falar em modelo faz-se referência a uma representação ou construção simplificada de uma série de fatos, neste caso lingüísticos (Moreno, 2000:63). Consideramos como um modelo ideal, a abstração e simplificação de uma língua realizada com a finalidade de ser convertida em exemplar. O modelo pode ser criado artificialmente ou pode ser selecionado entre as possibilidades que a realidade oferece. Moreno (2000:64) cita a teoria dos protótipos de Angel López García e define a lengua española como uma categoria mental prototípica à que se unem suas variantes dialetais. Os traços que fazem com que uma variedade seja considerada nuclear ou periférica dentro do protótipo estão relacionados com o prestígio, associado ao predomínio político, cultural, econômico e não simplesmente ao histórico. No mundo hispânico o dialeto castellano continua a ter uma importância considerável. Tanto dentro como fora de Espanha parece ser considerado que o melhor espanhol, o mais "puro", é aquele falado em Castilla la Vieja. Assim o melhor espanhol seria aquele que se aproxima mais desta variedade.

A questão do modelo a ser escolhido deve diferenciar entre: âmbito compartido, frecuencia de ocurrencias e lengua neutra. O primeiro depreende-se da análise dos sistemas e é conseqüência de um estudo comparativo. O segundo, alcança-se por meio do estudo dos usos verbais. O terceiro, a lengua neutra, é o que resta quando não é dada uma atenção específica às diferentes situações nas quais acontece a produção lingüística, 
segundo Francisco Moreno (2000:68) citando Corner. Portanto não tem por que existir coincidências entre o comum e o freqüente, mas é normal que existam entre o freqüente e o neutro. A língua então é resultado de um processo de abstração e simplificação a partir dos usos contextualizados. Isso significa que a língua inclui o comum, além dos elementos mais freqüentes e neutros. É a chamada língua padrão, lengua estandar, ou língua geral, segundo Moreno citando Córner (2000:68).

Voltando ao titulo do apartado, Que español estudiar, concluímos que o modelo de español escolhido para estudar as formas verbais é aquele que acabamos de chamar de língua geral ou lengua estandar para fazer referência a uma série de usos preponderantes e prestigiosos. Alguns autores citados ao longo deste trabalho usam esse mesmo modelo de língua em seus estudos. É o caso de Angeles Sastre (1997:17), por exemplo, que em seu livro sobre o subjuntivo no español estuda o funcionamento do subsistema verbal do subjuntivo no español estandar actual. Cientes da complexidade do estudo de uma língua que, por sua vastidão geográfica, é uma ao tempo que são múltiplas suas variantes, fazemos nossas as palavras extraídas da Advertencia que abre o Esbozo de uma Nueva Gramática dela Lengua Española (1986:5)

Se advertirá en este Esbozo cierta desigualdad en el desarrollo de diferentes materias $\mathrm{o}$, en ocasiones, una aparente falta de atención a variedades lingüísticas de diverso tipo propias de los países americanos, que no es debida sino a información insuficiente en cuanto a su extensión y aceptación en las distintas zonas.

Serão utilizados como corpus textos literários escritos pertencentes ao âmbito da ficção por reunir várias qualidades que facilitaram a verificação do funcionamento do sistema verbal desde uma abordagem semiótica. Por serem textos literários, são representativos da norma culta. Por outro lado, o âmbito da ficção literária permite também apresentar exemplos de língua popular, na fala das personagens, por exemplo, sempre dentro do correto, admitido e consentido socialmente. Como fonte de numerosos exemplos, será utilizado o Corpus de referencia del español actual (CREA), limitando cronologicamente os textos à segunda metade do século XX e século XXI, além de serem 
amostras recolhidas de textos de autores de diferentes nacionalidades, o que confirma a idéia de unidade da língua.

Estabelece-se como objetivo do presente trabalho estudar a categoria do tempo, como uma categoria da linguagem intrínseca à narração, nas suas manifestações peculiares na língua espanhola, de um ponto de vista semiótico, considerando o momento da enunciação como o eixo em torno do qual se articulam a anterioridade e a posterioridade enquanto experiência fundamental do tempo em todas as línguas. Visa-se a estudar a organização formal, concreta, da língua espanhola, tomando como corpus textos literários de diferentes países, em que o espanhol seja a primeira língua, como representantes da norma culta.

\section{O tempo sistematizado}

\subsection{Dos tempos verbais}

Tudo está no tempo, exceto o próprio tempo.

Benveniste

Todas as línguas possuem categorias básicas que se realizam quando o ser humano as realiza no discurso com um ato de língua. Categorias, sistematizadas de diversas maneiras em função das diferentes línguas, como tempo e pessoa, estão presentes em todas as línguas porque formam parte da natureza humana.

O tempo, desde seus diversos ângulos de visão, segundo Benveniste (Benveniste, 1989, p.23), pode ser considerado como tempo físico, o tempo do mundo, aquele contínuo, uniforme, lineal, exterior ao homem, que cada individuo vivencia de maneira particular, 
assim o tempo pode transcorrer lento o rápido, por exemplo, dependendo da situação e da vivencia de cada pessoa. O tempo crônico, no qual os acontecimentos da vida dos homens se desenvolvem, aquele que é possível percorrer voltando às lembranças, do presente para o passado e vice-versa, enquanto a nossa vida continua em uma única direção. É aquele que o homem mede agrupando-o em dias, meses, anos ou dividindo-o em horas, minutos, segundos, podendo assim ser mensurado. O tempo crônico é medido a partir de um ponto zero, um acontecimento excepcional, o nascimento de Cristo, por exemplo, na nossa cultura, que lhe outorga um caráter estativo. Já que tudo acontece no tempo, os fatos podem se situar uns em relação aos outros, adquirindo uma qualidade diretiva.

Benveniste conclui esta classificação do tempo com a descrição do tempo lingüístico. É um tempo ligado ao tempo da fala, que se reinventa em cada ato de enunciação, ordena-se e define-se em função do discurso.

O discurso instaura dois momentos. Em primeiro lugar, o momento da enunciação, o agora, e, em contraposição, o momento do então. Com base nesses dois momentos, fundamentam-se as oposições temporais da língua.

O tempo presente é o momento contemporâneo ao ato da enunciação. Considerando que em cada ato de enunciação o enunciador o reinventa, esse tempo não pode ser localizado como um tempo crônico e sim como um tempo do discurso. Gerado pelo discurso, o agora vai permanecer como um eixo que ordena a categoria topológica da concomitância vs não-concomitância, articulando-se por sua vez em anterioridade vs posterioridade ${ }^{7}$. Esse eixo faz com que todos os tempos estejam relacionados à enunciação. O que significam essas categorias no discurso? A concomitância refere-se ao momento simultâneo entre a narração e o narrado, que permanece ao longo do discurso, e, conseqüentemente, a não-concomitância faz menção aos momentos não simultâneos, anteriores ao acontecimento, aqueles que são evocados pela memória, e os posteriores ao acontecimento, aqueles que ainda não se deram. Assim anterioridade e posterioridade são

\footnotetext{
${ }^{7}$ FIORIN, José Luiz (2001). As astúcias da enunciação. As categorias de pessoa, espaço e tempo. São Paulo. Ática. (p. 142-143).
} 
pontos de vista para trás e para frente em relação ao momento do fazer enunciativo. O eixo ordenador do tempo é, pois, sempre o momento da enunciação. ${ }^{8}$

Existe uma espécie de contrato fiduciário entre o enunciador e o enunciatário, de forma que o agora do enunciador é aceito como o agora do enunciatário, já que a aceitação do tempo do enunciador por parte do enunciatário possibilita a compreensão da fala assim como a aceitação de uma temporalidade comum, que por sua vez será o agora do enunciatário na sua vez de se tornar enunciador. Esse tempo do discurso não se limita às divisões do tempo crônico, não pertence a uma única subjetividade e sim pressupõe uma interação lingüística,. Lembrando as palavras de Benveniste (Benveniste, 1989, p.78), ele [o tempo lingüístico] funciona como um fator de intersubjetividade, e de unipessoal ele deveria se tornar onipessoal.

Devem ser considerados dois aspectos a respeito do tempo lingüístico. O primeiro, quando a recepção não é simultânea à produção (uma carta, um bilhete, um recado na secretária eletrônica, por exemplo). Nesse caso o advérbio hoje, por exemplo, deixa de ter o valor de presente propriamente dito no tempo lingüístico, porque poderia ser proferido em qualquer momento. $\mathrm{O}$ meio de tornar o advérbio inteligível seria a ancoragem no tempo crônico com uma data, por exemplo. Igualmente, as outras categorias da enunciação, pessoa e espaço, podem ser reconhecidas unicamente pelos participantes da troca lingüística e, portanto, devem ser ancoradas em coordenadas espaço-temporais e actanciais para poder ser inteligíveis.

Mesmo considerando que a especificidade do tempo lingüístico reside no fato de que o momento da enunciação o ordena, é preciso lembrar que a ordem (sucessividade e simultaneidade), duração e direção (retrospectiva e prospectiva) são comuns ao tempo de modo geral. (Fiorin, 2001, p. 144).

A sucessão de estados e transformações que aparece representada no texto é outro aspecto que deve ser levado em consideração no tempo lingüístico: as relações de

\footnotetext{
${ }^{8}$ Ver FIORIN (p. 143).
} 
anterioridade e posterioridade. Tais relações de sucessividade podem estar ordenadas em relação ao marco temporal instalado no texto pela própria enunciação, o agora, eixo que ordena e gera a enunciação, ou em relação aos marcos temporais, os momentos de referência, instalados no texto, ou seja, no enunciado.

Daí pode se deduzir que existem na língua dois sistemas temporais:

○ um diretamente relacionado ao momento da enunciação (agora, eixo que permeia a enunciação) $\longrightarrow$ sistema enunciativo;

○ outro que ordena os momentos de referência que aparecem no enunciado $\longrightarrow$ sistema enuncivo.

Ambos os sistemas estão relacionados entre si. O momento de referência está relacionado ao momento da enunciação, já que esse é o eixo fundamental de ordenação da língua (Fiorin, 2001, p.146). Ao momento da enunciação (ME) aplica-se a categoria topológica concomitância vs não-concomitância (anterioridade vs posterioridade). Obtêmse, assim, três momentos de referência (MR): concomitante, anterior e posterior ao momento da enunciação (ME). Quando o momento de referência é concomitante ao momento da enunciação, usa-se o sistema enunciativo, já que tudo vai fazer referência à enunciação. Esse momento de referência ficará explicitado, ou ancorado, caso não seja simultâneo à produção (a carta, o bilhete). Quando não é concomitante, ou seja, anterior ou posterior ao momento da enunciação, usa-se o sistema enuncivo. Nesse caso, a anterioridade ou a posterioridade deverá ser sempre explicitada.

Finalmente, o momento dos acontecimentos (estados e transformações) ordena-se em função dos momentos de referência. Aplica-se a categoria topológica concomitância vs não-concomitância (anterioridade vs posterioridade) aos momentos do acontecimento.

São três os momentos estruturais que constituem o sistema temporal:

○ momento da enunciação (ME);

○ momento de referência (MR);

- momento do acontecimento (MA). 


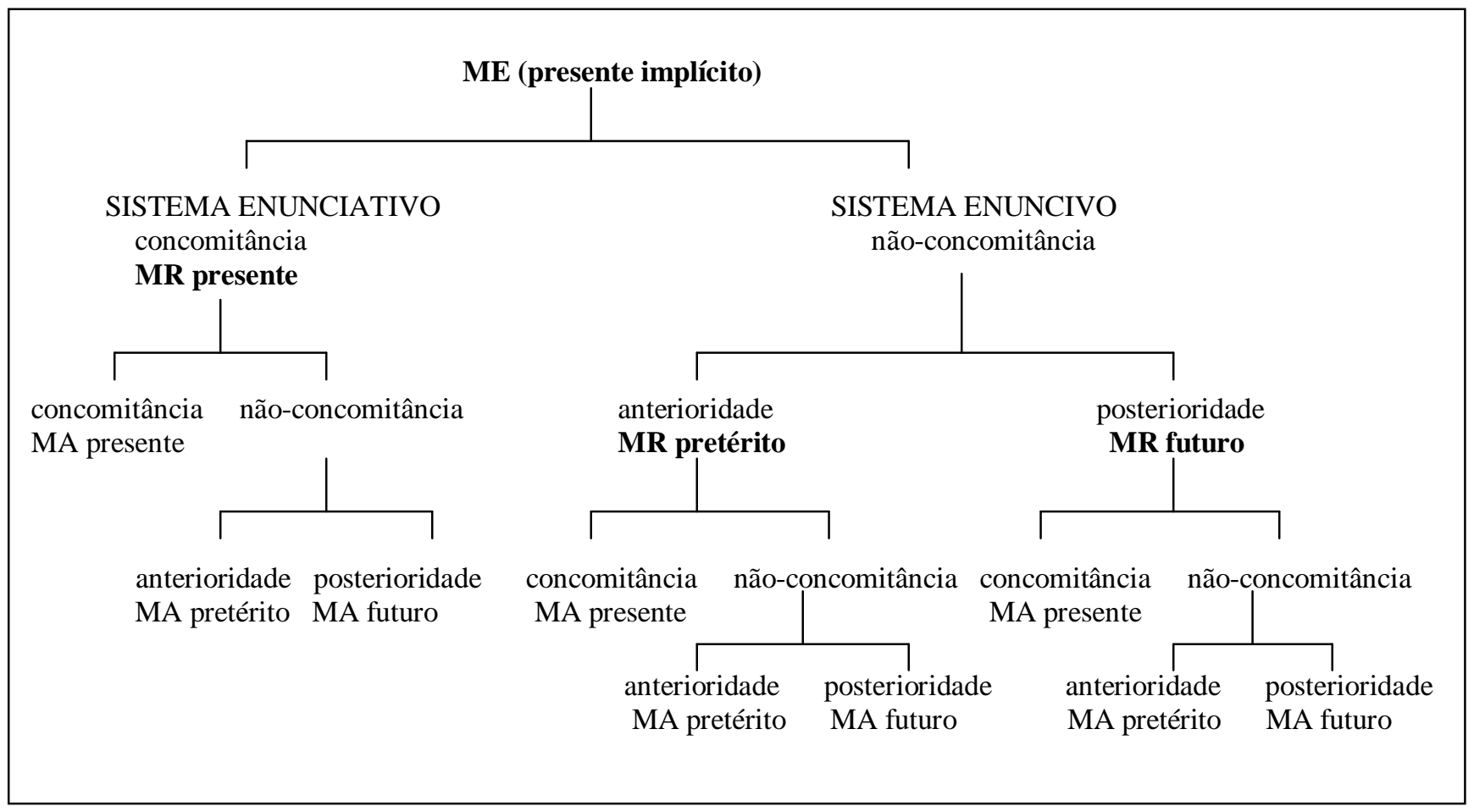

Quadro 1

(Fiorin, 2001: 146)

É possível concluir que se opera com dois eixos:

○ o primeiro deriva da aplicação da categoria topológica ao momento da enunciação (ME), o que resulta em três momentos de referência (MR) e dois sistemas temporais, um enunciativo e outro enuncivo. $\mathrm{O}$ sistema enunciativo cria um subsistema centrado em um momento de referência presente. O sistema enunciativo produz dois subsistemas, um centrado em um momento de referência pretérito e outro em um momento de referência futuro;

○ outro eixo decorre da utilização da categoria topológica em relação aos momentos de referência, distinguindo uma relação de simultaneidade, de anterioridade ou de posterioridade entre o momento do acontecimento (MA) e o momento de referência (MR). 
A projeção dos tempos verbais no enunciado tem como resultado uma debreagem temporal:

○ enunciativa, quando se projetam no enunciado os tempos do sistema enunciativo;

○ enunciva, quando se projetam no enunciado os tempos do sistema enuncivo.

A debreagem será:

○ de primeiro grau, quando os tempos verbais estiverem relacionados à voz do narrador;

○ de segundo grau, quando existir uma delegação da voz do narrador e, portanto, estiver relacionada ao $e u$ interlocutor.

Considerando esses princípios teóricos, apresentaremos a seguir uma relação dos tempos verbais do modo indicativo do espanhol, que serão estudados para descrever como se concretizam nessa língua, em um primeiro momento, a debreagem e, em outro capítulo posterior, a embreagem. A nomenclatura utilizada é a empregada pela Real Academia Española (RAE) no Esbozo de una Nueva Gramática de la Lengua Española de 1973 :

Presente

canto

Pretérito imperfecto

cantaba

Pretérito perfecto simple

canté

Futuro simple

cantaré

Condicional simple

cantaría

\section{Pretérito perfecto compuesto}

he cantado

Pretérito pluscuamperfecto

había cantado

Pretérito anterior

hube cantado

Futuro compuesto

habré cantado

Condicional compuesto

habría cantado 


\section{- Sistema enunciativo}

Como foi dito acima, os tempos verbais organizam-se em dois sistemas temporais, enunciativo e enuncivo. A debreagem dos tempos do sistema enunciativo no espanhol poderia ser representada no seguinte esquema:

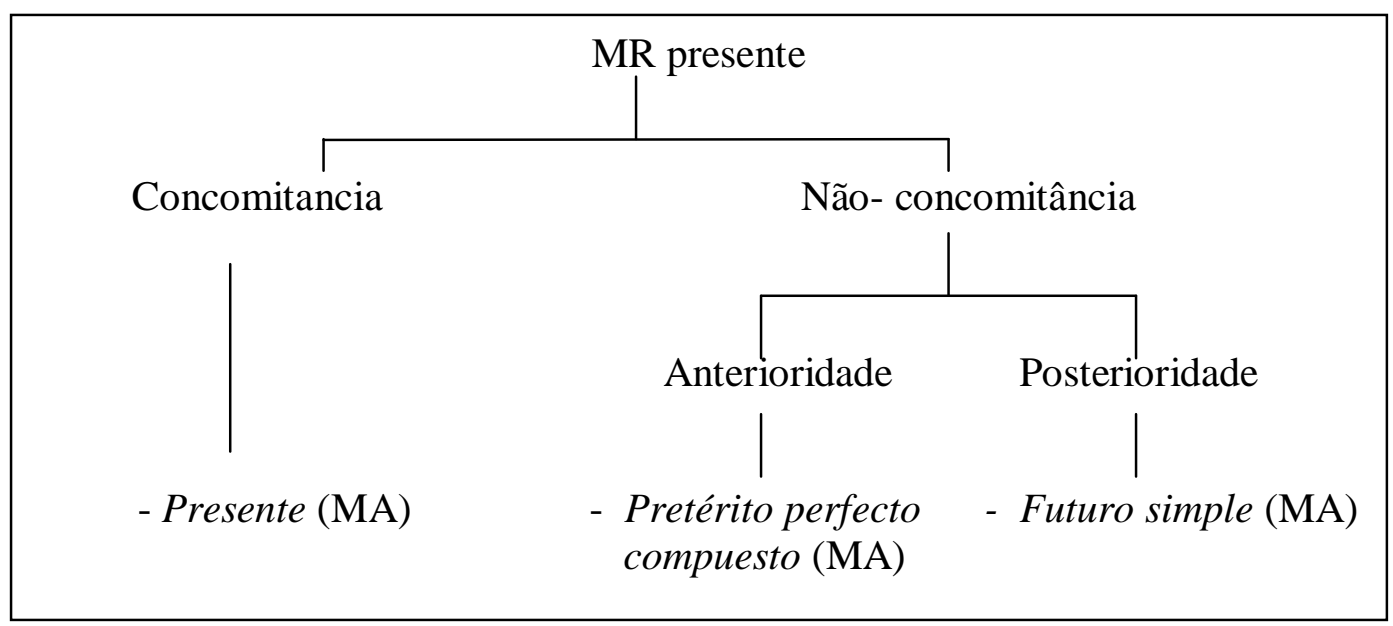

Quadro 2

\section{Concomitância}

O presente marca uma tripla coincidência entre o momento do acontecimento (MA), o momento de referência (MR) e o momento da enunciação (MA). Como o momento da enunciação é difícil de precisar, pois está constantemente fugindo, essa coincidência deve ser entendida como a simultaneidade que existe entre algum ponto do momento de referência e o momento da enunciação. O momento de referência deve englobar o momento da enunciação, já que se reconstrói o presente com instantes que já aconteceram e com os que ainda vão acontecer, mas o que sempre deve coincidir é o momento de referência e o momento do acontecimento.

Podemos enumerar três casos de relações entre o momento de referência (MR) e o momento da enunciação (ME):

1. presente pontual, quando o MR e o ME coincidem: 
Tomemos como exemplos as seguintes manchetes do jornal El País:

Isralíes e palestinos logran un acuerdo para abrir las fronteras de Gaza.

(El País, 15 de novembro, 2005, atualizado às 15:45)

O verbo grifado, no presente do indicativo, expressa um acontecimento cujo momento de referência é concomitante ao momento da enunciação, que seria a data da publicação do jornal, 15 de novembro de 2005.

Outro exemplo, o poema de Oliverio Girondo:

\section{PUEDES JUNTAR LAS MANOS}

LA GENTE dice:

Polvo,

Sideral,

Funerario,

y se queda tranquila,

contenta,

satisfecha.

Pero escucha ese grillo,

esa brizna de noche,

de vida enloquecida.

Ahora es cuando canta.

Ahora

Y no mañana.

Precisamente ahora.

Aquí.

A nuestro lado...

Como si no pudiera cantar en otra parte.

¿Comprendes?

Yo tampoco. 
Yo no comprendo nada.

\section{Oliverio Girondo ${ }^{9}$}

Analisando o verso grifado, o momento do acontecimento expressado pelo presente do indicativo "canta" coincide pontualmente com o momento de referência expresso por "es", reforçado pelos advérbios: "ahora", "aquî", "precisamente ahora". O momento de referência é, neste caso, o momento da enunciação, sendo concomitantes, assim, os três momentos.

2. Presente durativo, quando o MR é mais longo que o ME.

A duração é variável, e pode ser contínua ou descontínua:

- duração descontínua: presente iterativo

- ¡Y qué puedo hacer! Mi padre quiere que lo afeite cada sábado. Así vas aprendiendo, dice, y agradece que se preste sin miedo a que lo desolles vivo. $^{10}$

O MR é de duração mais longa que o ME, com a qual coincide em um ponto. Por sua vez, o MR repete-se ao longo dos vários sábados, o que o faz coincidir com o MA quiere e afeite que, igualmente, repete-se. No entanto existe um único ME que coincide com o MR em um determinado ponto. Fernandez Ramirez (Fdez. Ramírez, 1986: 214) define como presente cíclico o presente de verbos perfectivos que descrevem fatos habituais o repetidos, em algumas ocasiões reforçados por expressões temporais.

- duração contínua: presente de continuidade.

\footnotetext{
${ }^{9}$ GIRONDO, Oliverio. (1995). Veinte poemas para ser leídos en el tranvía. Calcomanías y otros poemas. Madrid: Visor (p.35).

${ }^{10}$ MARSÈ, Juan (2000) Rabos de lagartija. Barcelona: Lumen (p.90) (CREA 18/02/07).
} 
Hoy me gusta la vida mucho menos

Pero siempre me gusta vivir: ya lo decía.

$$
\left(\text { Cesar Vallejo }{ }^{11}\right)
$$

o mesmo tempo e pessoa verbal exprime diferentes sentidos dependendo do advérbio. No primeiro verso, o advérbio hoy adverte da pontualidade do presente referido a um fato cujo momento de referência é concomitante ao momento da enunciação. Já o advérbio siempre expressa a idéia de continuidade do presente cujo momento de referencia é mais amplo que o momento da enunciação.

3. Presente omnitemporal ou gnómico, quando o MR é ilimitado e, por conseguinte, o MA também. Ao se tratar de um MR que leva implícito um sempre, o momento do estado gira indica que sempre vai ser assim.

\section{La tierra gira alrededor del sol}

É o tempo usado para as verdades eternas, daí que seja usado no discurso científico, religioso ou popular. Aparece:

- nos provérbios:

El que no arriesga no pasa la mar ${ }^{12}$

- nas definições:

Tan solamente ahora que has comprendido que el amor es un caballo loco corriendo por el mar $^{13}$

- na descrição de estados considerados imutáveis:

\footnotetext{
${ }^{11}$ VALLEJO, César (1987). Poemas Humanos. España, aparta de mí este cáliz. Madrid: Castalia (p.100).

${ }^{12}$ GONZÁLEZ, Eladia (1999). Quien como Dios. Madrid: Espasa Calpe. (p. 383) (CREA 19/02/07).

${ }^{13}$ JIMÉNEZ-ARNAU, Joaquín (1977). Las Islas Transparentes. Barcelona: Destino. (p.187) (CREA 19/02/07).
} 
"Cuando el sol se hunde en el Océano", recita mentalmente Alexander, recordando los versos de Horacio.

-Cum sol Oceano subest -dice al oído de María. ${ }^{14}$

Salvador Fernández Ramírez, na sua gramática, classifica os usos do presente (Fdez. Ramírez, 1986: 215) como:

- presente general: aquele que anteriormente foi denominado como gnómico, utilizado para expressar conhecimento derivados da experiência ou que constituem juízos a priori. Cabe apontar que esses presentes são empregados, inclusive, na narração em imperfeito porque referem-se a características ou propriedades dos fatos da narração, quando o narrador considera pertinentes as especificações.

Era aquel momento del día en que la luz del sol nos acaricia incitándonos a abandonar el mundo de los sueños.

- $\quad$ presente caracterizador ou de clase: aquele que introduz traços ou peculiaridades atribuídas ao objeto, pessoa, situação da que se fala. Normalmente aparecem em orações adjetivas de relativo dentro de narrações que podem ser em passado.

Empecé a sospechar de ese amigo de tu hermano, de ese tío que yo siempre te he dicho que tiene pinta de anormal, el que es arquitecto y hace carteles para el ayuntamiento ${ }^{15}$.

- presente empírico: aquele que designa um fato comprovado pela experiência ou pela observação.

${ }^{14}$ ARIAS, Mariano (1991). El silencio de las palabras. Barcelona: Destino. (p. 82) (CREA 19/02/07).

${ }^{15}$ HIDALGO, Manuel (1998). Azucena que juega al tenis. Madrid: Mondadori (p.20) (CREA 18/02/07). 
Irene estaba a punto de entender que si había llegado a un profundo conocimiento de sí misma, fue gracias a su aprendizaje por los senderos de la pasión, en lo que ésta le reportó de plenitud, pero también de decadencia, pues en el fondo se trataba de dos caras complementarias de lo mismo, ya que tiene que haber noche para que haya día, y amargura para que renazca la alegría ${ }^{16}$.

- presente normativo: aquele que é utilizado para descrever a forma correta, ou supostamente correta, de realizar uma ação.

Cualquier movimiento se convierte en un signo o una señal cuando se acerca un cambio, pensó, y dejó de mirar la bahía y la siguió y le pareció que se adentraban en el pueblo por su parte más alta aunque volvió ella a descender por caminos y calles medio destruidas aún y a ascender de nuevo como se camina por un laberinto conocido dando rodeos a veces, o yendo en una dirección que contradice la anterior con la misma seguridad que si la guiara un objetivo que sólo ella era capaz de reconocer, sin dejar de canturrear y sin cambiar el ritmo ni detenerse ni aminorar la marcha ni sofocarse ${ }^{17}$.

Todos os usos explicados anteriormente, recolhidos por Salvador Fernández (Fernandez, 1982), compartilham com o presente gnómico explicado por Fiorin um momento de referência (MR) ilimitado, que leva implícito um sempre, e, por conseguinte, o MA também.

Os outros usos do presente, como presente histórico, presente prospectivo e voluntativo e presente perfectivo e irreal, que Fernández Ramírez apresenta na sua

\footnotetext{
${ }^{16}$ GARCÍA SÁNCHEZ, Javier (1991). La historia más triste. Barcelona: Anagrama (p. 606) (CREA 18/02/07).

${ }^{17}$ REGÁS, Rosa. (1994) Azul. Barcelona: Destino (p.96) (CREA 18/02/07).
} 
gramática, serão estudados no capitulo dedicado à embreagem por tratar-se de casos de neutralização do passado ou do futuro pelo presente.

\section{Anterioridade}

A relação de anterioridade entre o momento do acontecimento (MA) e o momento de referência (MR) presente no espanhol, vem representada pelo pretérito perfecto compuesto, que A. Bello chamou de ante-presente.

Hay días en que me levanto con una esperanza demencial, momentos en los que siento que las posibilidades de una vida más humana están al alcance de nuestras manos. Éste es uno de esos días.

$\mathrm{Y}$, entonces, me he puesto a escribir casi a tientas en la madrugada, con urgencia, como quien saliera a la calle a pedir ayuda ante la amenaza de un incendio, o como un barco que, a punto de desaparecer, hiciera una última y ferviente seña a un puerto que sabe cercano pero ensordecido por el ruido de la ciudad y por la cantidad de letreros que le enturbian la mirada.

\section{Ernesto Sábato ${ }^{18}$}

O momento de referência aparece exprimido no texto pelo presente do indicativo. $\mathrm{O}$ presente hay, fazendo uso de expressões de tempo tais como días ou momentos nos quais acontecem as ações - me levanto, están, siento - , expressa o aspecto de descontinuidade. A relação de concomitância entre o momento de referência e o momento da enunciação está expressa pelo presente iterativo. O parágrafo fecha-se com o momento de referência presente concomitante ao momento da enunciação, um presente pontual, pois é nesse dia concreto que o acontecimento se insere no tempo. Com me he puesto a escribir é expressa a relação de anterioridade da concomitância. O momento do acontecimento é anterior ao momento da referência, que, por sua vez, é concomitante ao momento da enunciação. Ao longo desse dia concreto acontece a enunciação em um ponto concreto, e o momento de

\footnotetext{
${ }^{18}$ SÁBATO, Ernesto. (2002). La resistencia. Buenos Aires: Planeta. (p. 11).
} 
referência é mais longo que o momento da enunciação. O momento de referência, período do dia, pode ser fragmentado em instantes. Um deles coincide com o momento da enunciação, e outro, anterior à enunciação, com o acontecimento.

El rey Abdala II de Jordania ha aceptado la dimisión de al menos diez de sus más importantes asesores, en lo que parece ser la primera reacción oficial tras los atentados del pasado miércoles que causaron 57 muertos y un centenar de heridos.

(El País, 15 de novembro, 2005, atualizado às 22:45)

A relação de anterioridade da concomitância vem expressa por ha aceptado. $\mathrm{O}$ momento de referência é a data do jornal, o momento da enunciação. Por ser uma edição digital, é a última atualização, coincidente com um momento do dia que serve como momento de referência do acontecimento - a aceitação da renúncia de alguns dos seus assessores por parte do rei da Jordânia. Estamos no sistema enunciativo, onde o verbo marca a relação de anterioridade da concomitância com o momento da enunciação.

Ante-presente é a denominação empregada por Andrés Bello ${ }^{19}$ para o pretérito perfecto compuesto, e pretérito, a utilizada para o pretérito perfecto simple. A diferença entre ambos é explicada da seguinte forma:

Se dirá propiamente. "Él estuvo ayer en la ciudad, pero se ha vuelto hoy al campo". Se dice que una persona ha muerto cuando aun tenemos delante vestigios recientes de la existencia difunta; cuando aquellos a quienes hablamos están creyendo que esa persona vive; en una palabra siempre que va envuelta en el verbo alguna relación a lo presente. [...]. "Cervantes estuvo cautivo en Argel"; se trata de la persona física que es cosa totalmente pasada. "Cervantes ha sido universalmente admirado"; se trata del escritor que vive y vivirá eternamente en sus obras. (Bello, 1984: 202-203).

${ }^{19}$ BELLO, Andrés. (2004). Gramática de la Lengua Catellana. Madrid: EDAF. 
Com efeito, a diferença entre ante-presente e pretérito vem marcada pela duração do tempo que alcança o presente ou não. No entanto, os exemplos colocados relativos a Cervantes, do ponto de vista da teoria da enunciação, pertenceriam a dois sistemas diferentes. No caso de "Cervantes ha sido universalmente admirado", estamos no sistema enunciativo, e o verbo marca a relação de anterioridade da concomitância entre o momento de referência e o momento da enunciação. Por outro lado, o exemplo "Cervantes estuvo cautivo en Argel" situa-se no sistema enuncivo, pois o verbo marca a concomitância entre o momento do acontecimento (MA) passado com o momento de referência (MR) anterior ao momento da enunciação.

Utilizando a nomenclatura empregada por Bello, Emilio Alarcos Llorach ${ }^{20}$ aborda a diferença entre ambos os tempos não como uma oposição diretamente entre o antepresente e o pretérito, e sim como uma oposição através do presente.

(...) la perspectiva de pretérito y la anterioridad en la perspectiva de presente pueden coincidir en sus referencias y producir la confusión en el uso de las dos formas. Una misma realidad puede designarse con una u otra forma, dependiendo de la perspectiva (temporal o psicológica) que adopte el hablante. Compárense estas dos secuencias:

El día 2 se iniciaron las hostilidades.

Este mes se han iniciado las hostilidades.

La diferencia de contenido estriba en que se sitúa un mismo hecho, anterior al momento del habla en dos segmentos temporales diversos: al decir el día dos nos referimos a un segmento en que no está incluido el momento del habla; al decir este mes, en cambio, el inicio de las hostilidades se coloca en un trecho temporal que también abarca el momento en que se habla. Así un mismo acontecimiento anterior, se expresa, según la perspectiva adoptada, con el antepresente o con el pretérito. (Alarcos, 1994: 209).

\footnotetext{
${ }^{20}$ ALARCOS LLORACH, Emilio. (1994). Gramática de la Lengua Española. Real Academia Española (colección Nebrija y Bello). Madrid: Espasa. (p. 209).
} 
Efetivamente, os dois enunciados estão situados em dois sistemas temporais diferentes: um sistema enunciativo, cujo MR presente engloba o momento da enunciação, para o antepresente na terminologia de Bello, e um sistema enuncivo, cujo MR passado é anterior ao momento da enunciação. O fato de se precisar de uma data, por exemplo, referência do tempo cronológico, para ancorar o tempo lingüístico, pode causar essa confusão na hora de sistematizar o tempo.

Alarcos aplica a mesma distribuição do tempo no caso de ¿Ha vuelto Juan?, em que se usa a forma composta, o antepresente, porque o regresso pelo qual se pergunta pode estar situado em qualquer instante do período de tempo que conclui quando a pergunta termina de ser formulada. A resposta, segundo Alarcos, pode ser Sí, regresó el sábado, sendo que o pretérito, efetivamente o regresso no sábado, poderia indicar um momento alheio ao momento da enunciação, cuja relação com o presente tem origem eixo que o próprio presente cria e que, portanto, sempre é levado em consideração.

Deve-se lembrar neste ponto (Esbozo: 1986: 466) que existem regiões, como o norte peninsular, Galicia e Astúrias, e grande parte da América Latina, que na língua oral preferem o uso do pretérito perfecto simple para expressar a relação de anterioridade da concomitância. Reserva-se a diferenciação entre esse pretérito e o pretérito perfecto compuesto para o uso literário e a norma culta escrita. Pelo contrário, a fala vulgar de Madri e da Argentina inclina-se pelo uso do pretérito perfecto compuesto tanto para representar a anterioridade da concomitância quanto a concomitância da anterioridade.

Concluindo, no espanhol, para expressar a relação de anterioridade ao momento de referência presente, concomitante com o momento da enunciação, usa-se o pretérito perfecto compuesto, com exceção dos casos citados. A anterioridade expressada pela forma verbal e por certos advérbios ou locuções adverbiais se exprime até o impreciso limite do começo do presente. Serão necessários, no entanto, precisar alguns aspectos do comportamento do pretérito perfecto simple a este respeito, para tal fin dedicaremos um apartado específico. 
Salvador Fernández Ramírez explica como os usos e valores desse tempo são numerosos devido à complexidade das suas propriedades aspectuais. Apresentam-se aqui alguns usos do preterito perfecto compuesto:

- perfecto cíclico de reiteración indeterminada: o enunciado geral tem um valor de verdade desligado de um tempo concreto de realização. Isto é, ao dizer viste não é possível desligar o enunciado de um tempo cronológico de realização, mesmo não expresso no enunciado, concomitância da anterioridade. No entanto, ao usar has visto o enunciado poderia adquirir um valor cíclico ou iterativo sem precisar de uma referência cronológica concreta.

Ves una película suya y ya has visto todas.

- O perfecto compuesto é o tempo empregado para comentar um ato que acontece na frente de todos.

[...] ha salido precipitadamente de la estancia para no soltar, delante del afligido, la terrible carcajada que aún resuena en los oídos del príncipe ${ }^{21}$.

- Perfecto empírico representam ações pontuais, repetidas, mas cuja reiteração esta delimitada no tempo pelo momento em que se enuncia o enunciado (Fdez. Ramírez, 1986: 249). Aparece freqüentemente em livros de memórias. Por exemplo, o título do livro de Pablo Neruda, Confieso que he vivido, o falante não pretende situar cronologicamente o fato mas testemunhar a sua própria existência.

${ }^{21}$ MOIX, Ana Maria (1994). Vals negro. Barcelona: Lumen (p.106) (CREA 19/02/07). 
- O pretérito perfecto compuesto refere-se a ações cujo efeito ainda permanece no momento da enunciação. Quando alguém fala:

Ése es mi lugar, así lo ha querido el cielo que sea yo el descubridor ${ }^{22}$.

Así lo ha querido, significa que o efeito da ação permanece e não que o momento do acontecimento mantenha uma relação de anterioridade da concomitância ao momento da enunciação.

- O pretérito perfecto compuesto prospectivo pode aparecer com valor de futuro em contextos em que faz referência a ações por aconterem. Não pode ser considerado uma embreagem, ou seja, uma neutralização de um tempo futuro porque na realidade o tempo futuro não poderia ser usado.

Te espero en mi casa a las cinco y si ha llamado Juan vamos a buscarle.

Esse ha llamado não está expressando a relação de anterioridade a respeito do momento da enunciação, muito pelo contrário refere-se a um acontecimento posterior ao momento da enunciação.

Os outros usos do pretérito perfecto compuesto como o perfecto prospectivo, perfecto de hechos antiguos o de épocas remotas, o perfecto que aparece nas notícias ou aquele usado no lugar do presente fictício, que Fernández Ramírez inclui na sua gramática, serão estudados no capitulo dedicado à embreagem por tratar-se de casos de neutralização do preterito perfecto simple ou do presente pelo preterito pefecto compuesto.

\section{Posterioridade}


A relação de posterioridade do momento do acontecimento (MA) com o momento de referência (MR) presente é indicada pelo futuro simple.

O futuro é um tempo verbal cheio de nuances significativas que superam em muito a simples relação de posterioridade da concomitância (Fdez. Ramírez, 1986: 285). Por exemplo, o título do romance de Juan Marsé, Un día volveré, coloca um acontecimento posterior, futuro, em relação ao momento de referência, que coincide com o momento da enunciação. No entanto, esse enunciado, un día volveré, fora de qualquer contexto, pode comunicar:

- uma ação por vir num futuro próximo ou longínquo (futuro prospectivo);

- uma predisposição intencional para que tal ação aconteça, tornando possível transitar desde a confiança até o desejo

(futuro voluntativo);

- uma conclusão lógica e necessária, consequiência de uma série de premissas ou, também, uma obrigação do sujeito

(futuro de necesidad);

- uma suposição, algo que se imagina ou considera provável, embora não se possuam provas conclusivas para poder afirmar tal fato com certeza (futuro de conjetura).

O futuro simple, no sistema enunciativo, exprime a relação de posterioridade (MA) da concomitância (MR) com o momento da enunciação (ME).

\footnotetext{
${ }^{22}$ MARTÍN DEL CAMPO, David (1976). Las rojas son las carreteras. México D.F.: Joaquín Mortiz. (p.59) (CREA 19/02/07).
} 
Utiliza-se também o futuro com a idéia de mandado ou ordem ${ }^{23}$; nesse caso, o futuro incide em acontecimentos posteriores ao momento de referência presente, concomitante, por sua vez, com o momento da enunciação:

- Mandado para o futuro:

No entrarás en esa galería: [...] te dirigirás directamente a la puerta de la salida $^{24}$.

○ Mandados gerais, omnitemporais:

Primer mandamiento: no amarás a otra ciudad que París. Segundo mandamiento: no invocarás el nombre de París en vano. Qué lindo ${ }^{25}$.

○ No diálogo, última ordem:

Y así la vida continuará porque lo mando yo, con tu sacro permiso ${ }^{26}$.

Indica aproximação ou probabilidade:

Cuando te escribo esta postal, en Barcelona serán las seis de la tarde y aquí en Shanghai es la una de la madrugada ${ }^{27}$.

Tal como no português, expressa o efeito de uma causa:

Si hay una clave, y tú la descubres, saldrás de aquí. Pero si no la hay, no saldrás nunca ${ }^{28}$.

Para concluir, os versos de Pedro Salinas ${ }^{29}$ servem como exemplo de como se estabelecem as relações de tempo no espanhol no sistema enunciativo.

${ }^{23}$ GARCÍA SANTOS, Juan Felipe (1993). Sintaxis del español. Nivel de perfeccionamiento. Madrid: Santillana (p. 10).

${ }^{24}$ MERINO, José María (1995). La orilla oscura. Madrid: Alfaguara (p.345) (CREA 19/02/07).

${ }^{25}$ MARTíNEZ, Tomás Eloy (2002). El vuelo de la reina. Madrid: Alfaguara (p.81) (CREA 19/02/07)

${ }^{26}$ MOIX, Terenci (2002). El arpista ciego. Una fantasía d el reinado de Tutankamon. Barcelona: Planeta. (p.231) (CREA 19/02/07).

${ }^{27}$ MARSÉ, Juan (1996). El embrujo de Shangai. Barcelona: Plaza \& Janés (p.126) (CREA 19/02/07).

${ }^{28}$ SOMOZA, José Carlos (2000). La caverna de las ideas. Madrid: Alfaguara (p.318) (CREA 19/02/07).

${ }^{29}$ SALINAS, Pedro (1985). La voz a ti debida. Razón de amor. Madrid: Castalia (p.49). 
Porque has vuelto los misterios

del revés. Y tus enigmas,

lo que nunca entenderás,

son esas cosas tan claras:

la arena donde te tiendes,

la marcha de tu reló

y el tierno cuerpo rosado

que te encuentras en tu espejo

cada día al despertar,

y es el tuyo. Los prodigios

que están descifrados ya.

Os verbos grifados permitem reconstruir o sistema temporal da concomitância. A partir do verbo de estado "son", o momento do acontecimento é simultâneo ou concomitante ao momento de referência, que é concomitante ao momento da enunciação. O presente está reforçado pelos outros verbos no presente: "te tiendes", "te encuentras", "es", "están". Para a idéia de presente contribuem a expressão de tempo "cada día", que acrescenta o matiz da continuidade iterativa do presente, e o advérbio "ya", que adiciona um matiz pontual e conclusivo. A concomitância tem seu contraponto na nãoconcomitância, desdobrada em anterioridade e posterioridade. A relação da anterioridade da concomitância está expressa no texto pelo "has vuelto", pretérito perfecto compuesto, e a relação de posterioridade da concomitância pelo "entenderás”, futuro simple.

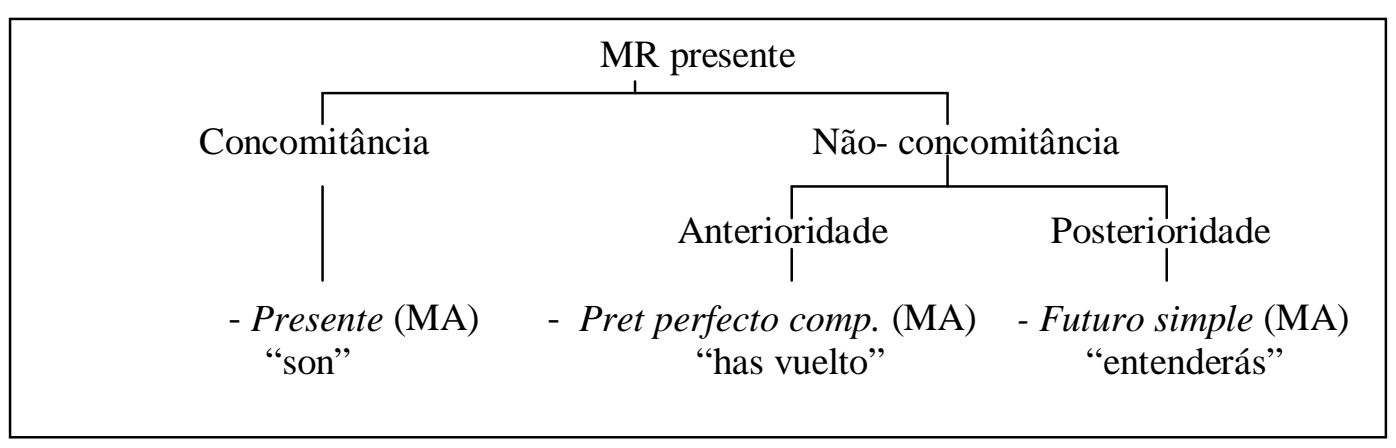

Quadro 3 


\section{- Sistema enuncivo}

O sistema enuncivo ordena os tempos verbais em dois subsistemas, um centrado no MR pretérito e outro centrado no MR futuro. Deve-se lembrar neste ponto que a temporalidade lingüística demarcada em suas três articulações é muito limitada. Assim, seguindo o eixo criado pelo agora, dois momentos acontecem a partir dele, ontem e amanhã. Numa visão retrospectiva, além do ontem, o tempo lingüístico encontra-se com o tempo cronológico para marcar os momentos de referência passados (uma data, expressões como "a semana passada", "há dez dias", etc.), procedimento denominado ancoragem.

A continuação o primeiro subsistema seria:

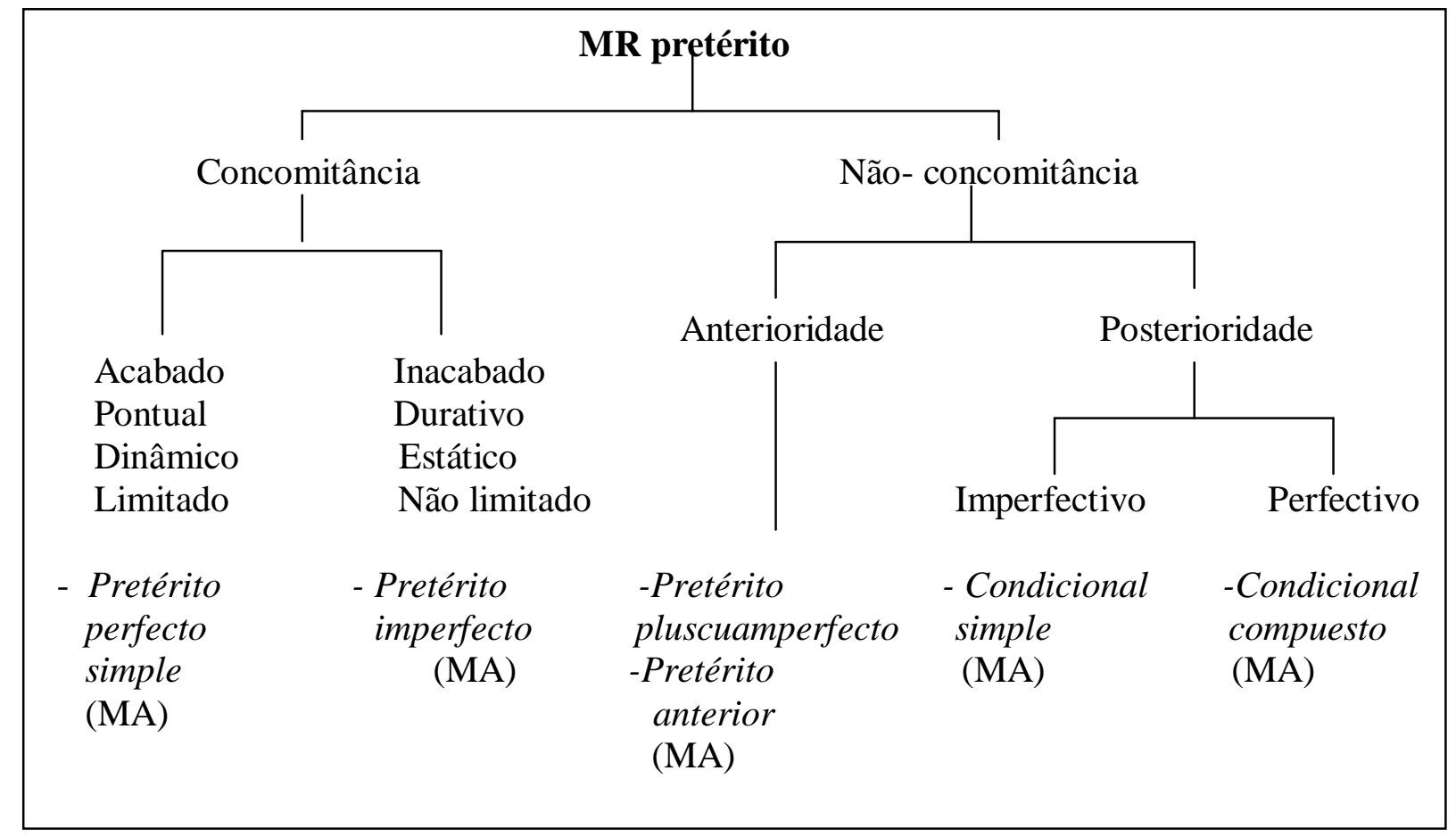

Quadro 4

\section{Concomitância}


A concomitância em relação a um MR pretérito pode exprimir-se por um pretérito imperfecto e/ou por um pretérito perfecto simple. A diferença entre eles no espanhol reside num valor aspectual distinto, assim como acontece no português:

- Pretérito imperfecto marca um aspecto: inacabado, durativo, estático, não limitado.

- Pretérito perfecto simple marca um aspecto: acabado, pontual, dinâmico, limitado.

Nos seguintes exemplos, comparam-se os dois tempos:

En 1492 Cristobal Colón llegó a América.

En 1492 Cristobal Colon llegaba a América.

Ambos os tempos, tanto llegó quanto llegaba, só fazem referência ao momento do acontecimento (MA) concomitante ao momento de referência (MR); nesse caso, a data (1492), é o elemento do tempo cronológico que serve para ancorar o tempo lingüístico. Segundo Fiorin (Fiorin, 2001: 155), no primeiro caso estamos diante de uma ação acabada, considerada como uma descontinuidade, um ponto, na continuidade do momento de referência (ano 1492), sendo portanto algo dinâmico, visto a partir do exterior. No segundo caso, a ação é considerada inacabada, continua dentro da continuidade do momento de referência, e estática, já que é vista a partir do interior, durante seu desenvolvimento.

O pretérito imperfecto, denominado por Bello co-pretérito porque "significa la coexistencia del atributo con una cosa pasada" (Bello, 1984: 201), tem um valor durativo:

- Duratividade contínua: expressa um fato contínuo no passado, imperfeito descritivo.

La torre de los Klein se alzaba en la linde de un frondoso parque rodeado por un muro de tres metros de alto erizado de vidrios afilados. El descuidado jardín estaba partido por un sendero de tierra roja que conducía 
hasta el pequeño porche de cuatro columnas con vitrales en la primera planta. $^{30}$

O momento de referência não aparece explicitado no texto. No entanto, os verbos em imperfecto indicam uma continuidade, uma duratividade, um estado das coisas. Os imperfeitos se alzaba, estaba, conducía, expressam a relação de concomitância entre o momento do acontecimento e o momento de referência passado, embora não explicitado, ou seja, anterior ao momento da enunciação.

- Duratividade descontínua ou iteratividade: expressa um fato que se repete no passado.

Tarde a tarde lo veían. Lejos de los demás, el gurí se sentaba a la sombra de la enramada, con la espalda contra el tronco de un árbol y la cabeza gacha ${ }^{31}$.

Neste caso, a relação de anterioridade do momento de referência em relação ao momento da enunciação vem expressa pelo imperfecto. No entanto, os imperfeitos veían e sentaba adquirem um valor iterativo graças à expressão temporal: "tarde a tarde".

Pode acontecer que o MR do imperfecto seja o pretérito perfecto simple, sendo que nesse caso o primeiro marca a relação de concomitância com o segundo. Bello diz a respeito disso que:

Poniendo al co-pretérito en relación con el pretérito, ¿se pueden expresar con él, no sólo las cosas que todavía subsisten, sino las verdades de duración indefinida o eterna? ¿Y no sería impropio decir: "Copérnico probó que la tierra giraba alrededor del sol"? Si es exacta la idea que acabo de dar del co-pretérito, la expresión es perfectamente correcta. Podría tolerarse

\footnotetext{
${ }^{30}$ MARSÉ, Juan (1982). Un día volveré. Barcelona: Plaza \& Janés (p.87).

${ }^{31}$ GALEANO, Eduardo (1987). Vagamundo y otros relatos. Montevideo: Ediciones el Chanchito (p.11).
} 
gira, mas entonces no veríamos por entre la mente de Copérnico el giro eterno de la tierra, como el sentido lo pide. (Bello, 1984: 201).

O imperfecto pode indicar uma ação na que se concluem varias outras ações pontuais citadas anteriormente.

Entró en casa, abrió la nevera, cogió una cerveza y unas aceitunas que acababa de abrir, sólo le faltó encender la tele y ponerse a ver el fútbol. Aquél exceso de confianza era el colmo.

O imperfecto era é concomitante ao momento de referência pretérito, anterior ao momento da enunciação, em que se concluem as ações pontuais expressadas pelo pretérito perfecto simple entró, abrió, cogió, faltó.

A "saída" não tinha começado, era uma intenção. Se fosse usado outro pretérito, a ação estaria acabada (salió, había salido). Segundo o Esbozo ${ }^{32}$ neste caso o aspecto sobrepõe-se à significação.

Caso particular é o imperfecto de cortesia, em que o MA estabelece uma relação de concomitância com o momento presente ${ }^{33}$, como em ¿Qué deseaba? ou quería hablar contigo. Nesses exemplos, o Esbozo afirma:

Frases como (éstas) se sienten como más amables que con el verbo en presente porque enunciamos modestamente nuestra pregunta o deseo en imperfecto, como algo iniciado cuya realización o perfección hacemos depender de la voluntad de nuestro interlocutor. (Esbozo, 1988: 467).

Salvador Fernández (Fdez. Ramírez, 1986: 270) recolhe na sua gramática alguns outros usos do pretérito imperfecto :

\footnotetext{
${ }^{32}$ REAL ACADEMIA ESPAÑOLA (1986). Esbozo de una Nueva Gramática de la Lengua Española. Madrid: Espasa Calpe (p.467).

${ }^{33}$ Será considerado como uma embreagem.
} 
- Imperfecto desiderativo de ocurrencia o inspiración; aparece em exclamações como 'Qué falta nos hacía!. Semelhante é aquele que expressa certa ironia ou incredulidade como !Ya decía yo!.

- Imperfecto de explicación o escusa: refere-se a fatos recentes. $\mathrm{O}$ falante deseja se desculpar, justificar ou expressar um pretexto por algum acontecimento.

- El caso es que tenía que estar en la editorial a primera hora de la tarde -se defendió é ${ }^{34}$.

- Imperfecto de sorpresa: freqüente na fala aparece geralmente acompanhado pelas partículas pero, no.

$$
\text { ¿Pero tú no estabas enfermo? }
$$

- Imperfecto de figuración: encontra-se na apódosis das orações condicionais se o tempo da prótasis for um imperfeito de subjuntivo.

Te juro que si pudiera me cortaba el dedo y luego lo pisoteaba, con sangre y todo, pero no me ahogues ${ }^{35}$.

Uma variante desse imperfecto de figuración é aquele que expressa sugestões ou conselhos, geralmente como interpretações contextuais da condicionalidade;

$$
\text { -Pues con todo y eso, yo que tú no lo publicaba sin pruebas }{ }^{36} \text {. }
$$

- Imperfectos cíclicos são aqueles que aparecem numa seqüência coordenados entre eles mas que em caso de ser substituídos por um

\footnotetext{
${ }^{34}$ MILLÁS, Juan José (2002). Dos mujeres en Praga. Madrid: Espasa Calpe (p.93) (CREA 19/02/07).

${ }^{35}$ VÁZQUEZ, Angel (1990). La vida perra de Juanita Narboni. Barcelona: Planeta (p.70) (CREA 19/02/07)
} 
pretérito perfecto simple perdem esse significado para passar a se referir a ações pontuais.

Apoyaba una mano, levantaba un pie, apoyaba la otra mano levantaba el otro pie y así entraba y salía varias veces de la cama antes de dormir.

- Imperfecto de conato faz referência a uma ação não completada, significa "iba a hacer alguna cosa", "estaba a punto de...".

Menos mal que has llegado, ya salía.

A "saída" não tinha começado, era uma intenção. Se fosse usado outro pretérito, a ação estaria acabada (salió, había salido). Segundo o Esbozo ${ }^{37}$ neste caso o aspecto sobrepõe-se à significação.

- Imperfecto lúdico é um tempo de repetição indeterminada que aparece geralmente nas brincadeiras infantis.

Se tiraban la pelota, gritaban y se reían.

O pretérito perfecto simple exprime a relação de concomitância entre o momento do acontecimento e o momento de referência anterior ao momento da enunciação. O pretérito perfecto simple expressa o aspecto limitado, acabado e pontual do acontecimento, alem de descontinuidade em relação ao momento de referência. Às vezes os fatos descritos pelo pretérito perfecto simple precisam de um certo tempo. No entanto, o interessante é que não descrevem a ação no seu percurso, mas fazem com que a percebamos na sua globalidade como um fato pontual.

\footnotetext{
${ }^{36}$ CEBRIÁN, Juan Luis (1986). La rusa. Barcelona: Círculo de Lectores (p.109) (CREA 19/02/07)

${ }^{37}$ REAL ACADEMIA ESPAÑOLA. (1986). Esbozo de una Nueva Gramática de la Lengua Española. Madrid: Espasa Calpe (p.467).
} 


\section{LA OVEJA NEGRA}

En un lejano país existió hace muchos años una Oveja negra.

Fue fusilada.

Un siglo después, el rebaño arrepentido le levantó una estatua ecuestre que quedó muy bien en el parque.

Así, en lo sucesivo, cada vez que aparecían ovejas negras eran rápidamente pasadas por las armas para que las futuras generaciones de ovejas pudieran ejercitarse también en la escultura ${ }^{38}$.

Em relação ao momento de referência ("hace muchos años") anterior ao momento da enunciação, o uso do pretérito perfecto simple (existió, fue fusilada, levantó, quedó) representa acontecimentos passados concomitantes a um momento determinado do pretérito que não leva em consideração a duração. Representa uma descontinuidade no momento de referência, como já foi dito, algo dinâmico visto a partir do exterior, ações acabadas.

De modo contrário, aparecían e eran pasadas, os imperfectos do texto, têm um valor de duratividade, nesse caso descontínua (iterativa), que se repete no passado, já que "cada vez que aparecían...eran pasadas por las armas".

Bello na sua gramática faz uma distinção entre os verbos desinentes e permanentes:

Nacer, morir, son verbos desinentes, porque luego que uno nace o muere, deja de nacer o morir; pero ser, ver, oir, son verbos permanentes, porque sin embargo de que la existencia, la visión o la audición sea desde el principio perfecta, puede seguir durando un gran tiempo. (Bello, 1984: 200).

Tal distinção é recolhida no Esbozo, considerando os verbos desinentes aqueles que, pelo seu significado, expressam a anterioridade da ação completa, e os verbos permanentes, aqueles em que o pretérito apresenta o momento no qual a ação conclui, chega à perfeição.

\footnotetext{
${ }^{38}$ MONTERROSO, Augusto (1991). La Oveja negra y demás fábulas. Barcelona: Anagrama. (p.23).
} 
La mujer, ante aquel horror, lanzó un grito.

Supe que había llamado.

No primeiro exemplo, lanzó, pelo seu significado, expressa uma ação perfectiva e completa. No caso de supe, a ação de saber permanece, pois quem sabe alguma coisa continua a saber, e o pretérito unicamente faz com que se denote o momento em que a ação de saber alcança a perfeição.

Alarcos também recolhe na sua gramática a idéia de Bello de que, coincidindo o momento de referência do pretérito e do co-pretérito na zona temporal, a segunda abarca em seu transcurso o primeiro. O autor atribui ao significado do verbo as diferenças entre ambos os tempos:

Los efectos variables de sentido, las referencias diversas que se comunican con cantabas (duración, iteración, incepción, previsión, negación, etc.) y con cantaste (conclusión, puntualidad, momentaneidad, efectividad, etc.) son mera consecuencia del contacto con la raíz verbal o con las otras unidades presentes en el enunciado. En todos los casos persiste la diferencia morfemática entre el valor no terminativo de cantabas y el terminativo de cantaste. (Alarcos, 1994: 206)

Os comentários das gramáticas referidas tiveram o intuito de apreciar a diferença a respeito da aplicação do modelo teórico de Fiorin (Fiorin, 2001), que independentemente da classificação semântica dos verbos, sistematiza as relações entre o momento do acontecimento, de referência e de enunciação em função do eixo criado pelo agora inerente à enunciação. No entanto, dada a complexidade das relações temporais que se estabelecem entre tais tempos do passado no espanhol (pretérito perfecto simple, pretérito perfecto compuesto) é pertinente voltar sobre este assunto em um item específico para tal propósito.

O pretérito perfecto simple indica iteratividade quando acompanhado de expressões iterativas. É a expressão que tem o valor iterativo, e não o pretérito. 
Edmundo nunca tuvo un contrato de empleado público como el mío, se fue varias veces de la televisión y alguna volvió.

O pretérito perfecto simple pode ser usado para expressar uma verdade geral quando for acompanhado por expressões como siempre, nunca, muchas veces, aconteceu no passado mas já acabou. Para dizer que a ação chega até o presente usamos no espanhol o pretérito perfeito composto situando a ação na anterioridade da concomitância.

Siempre tuvo suerte con las mujeres

O pretérito perfecto simple é o tempo da narração, que apresenta vários estados e transformações que se sucedem, ou seja, que são concomitantes aos diferentes momentos de referência pretéritos. Pelo contrário, o imperfecto apresenta os fatos como simultâneos ou formando um quadro na sua continuidade vinculados ao próprio momento de referência. É o tempo da descrição, como já vimos.

O pretérito pluscuamperfecto expressa a relação de anterioridade entre o momento do acontecimento (MA) e o momento de referência (MR) anterior. Em espanhol é um tempo composto, não tem forma simples, como acontece no português, e tem um aspecto perfectivo.

Había sido su mejor amigo desde que se conocieron en la facultad, ahora no podría soportar esa traición.

Em espanhol a relação de anterioridade entre o momento do acontecimento (MA) e o momento de referência (MR) pode ser expressa, também, pelo pretérito anterior. Atualmente esse tempo está saindo de uso, e é empregado unicamente em orações temporais e antecedido pelas locuções después que, luego que, así que, cuando, no bien, enseguida que, en cuanto, tan pronto como ou outras semelhantes. (Esbozo, 1988: 470) 
Coincide con el pluscuamperfecto en denotar un pasado del pasado. Se diferencian, sin embargo, en que el pluscuamperfecto la anterioridad puede ser mediata, mientras que en el pretérito anterior expresa sólo anterioridad inmediata. Como también el pluscuamperfecto y el perfecto simple pueden unirse a las locuciones antedichas (después que, luego que, etc.), las cuales por si solas indican sucesión inmediata, estos dos tiempos han eliminado al pretérito anterior del habla usual. Sólo la lengua literaria lo conserva más o menos. (Esbozo, 1988: 470)

Exemplo:

Así que hubo llegado se puso manos a la obra.

Así que llegó se puso manos a la obra.

O momento de referência anterior ao momento da enunciação, em ambas as orações, vem marcado pelo pretérito perfecto simple, puso. A relação de anterioridade da anterioridade aparece expressa pelo pretérito anterior, no primeiro caso, e pelo pretérito perfecto simple, no segundo exemplo. A expressão de tempo así que dá a idéia de sucessão imediata da ação, o que privilegiaria o uso do pretérito anterior, de não vê-se substituído na língua oral pelo pretérito perfecto simple e pelo pretérito pluscuamperfecto. Não me parece que seja. Penso que se trata de uma tendência simplificadora do sistema verbal no espanhol, uma mudança em curso (ou, plenamente realizada) com o pretérito perfeito simples assumindo os valores do anterior e substituindo-o. Neste caso, estamos diante de uma mudança no uso do pretérito perfecto simple que poderia ser incluso, junto com o pluscuamperfecto, nos tempos verbais que indicam anterioridade da anterioridade.

\section{Posterioridade}

O condicional simple e o condicional compuesto expressam a posterioridade do momento do acontecimento (MA) em relação a um momento de referência (MR) pretérito. O condicional é o futuro do momento passado.

Dijo que volvería lo antes posible. 
Estaba seguro de que resolvería ese problema sin dificultad.

Os verbos grifados, volvería e resolveria, no tempo condicional, expressam a posterioridade do momento do acontecimento em relação ao momento de referência anterior ao momento da enunciação, expresso por dijo, pretérito perfecto simple, na primeira oração, e por estaba, pretérito imperfecto, na segunda.

O condicional, assim como em português, tem o caráter de uma antecipação imaginária (Fiorin, 2001: 160). A ação que expressa é eventual ou hipotética.

O espanhol usa esse tempo para expressar a probabilidade referente ao passado.

Serían las diez cuando nos lo encontramos.

Tendría por entonces unos 35 o 40 años.

Existe também o uso de cortesia ao expressar um pedido, um desejo ou realizar uma pergunta.

Querría pedirte un favor.

Desearía hablar con usted.

O Esbozo chama a atenção para o fato de que, da mesma forma que o imperfecto de cortesía (quería, deseaba) resultam mais amáveis, o uso do condicional reforça a modéstia da expressão assim como a submissão do falante. (Esbozo, 1988: 474).

O condicional compuesto tem um caráter perfectivo, enquanto o simple é imperfectivo. O primeiro também marca a relação entre um momento do acontecimento posterior a um momento de referência pretérito, com a diferença de que estabelece uma relação com dois momentos, um anterior e outro posterior.

Esperaba que para cuando yo aterrizase en Madrid, las maletas ya habrían llegado. 
Examinando o momento do acontecimento expressado pelo condicional compuesto, habrían llegado, é possível apreciar a relação de posterioridade da anterioridade do momento de referência pretérito, esperaba, mas ainda há um momento do acontecimento posterior a essa posterioridade, que vem exprimido pelo subjuntivo aterrizase.

Para concluir, no seguinte texto aprecia-se as relações temporais do subsistema enuncivo do momento de referência anterior à enunciação.

Me dieron su foto y un sobre cerrado que contenía el pasaporte que él estaba esperando para poder huir y un fajo de extraños billetes españoles. Ése era el cebo, el pasaporte y el dinero que él había pedido, pero me dijeron que tuviera cuidado, porque recelaría, que nadie más que yo podría ir al interior y ejecutarlo sin peligro, y recordaron mi pasado de tantos años atrás y mi pasaporte británico, admirando o reprobando en silencio, con un poco de rencor la hechura de mi gabardina blanca y los puños de mi camisa con gemelos de oro.

Antonio Muñoz Molina ${ }^{39}$

Um pretérito perfecto simple inicia a narração no trecho escolhido, estabelecendo o momento de referência anterior ao momento da enunciação e situando o leitor no subsistema enuncivo do pretérito. O aspecto acabado, pontual, dinâmico e limitado de dieron abre caminho para os imperfectos, contenía e estaba, cujo aspecto inacabado, durativo, estático e não limitado situa o leitor na descrição do conteúdo do envelope e do estado de espera da personagem. Um novo imperfecto, era, enquadra como momento de referência o acontecimento anterior, expressado pelo pretérito pluscuamperfecto, había pedido, exprimindo assim a anterioridade da anterioridade. O condicional simple, recelaría e podría, expressa a antecipação do momento, isto é, a posterioridade do momento do acontecimento com relação ao momento de referência.

\section{MR pretérito}

Concomitância

Não- concomitância

Acabado

Inacabado

Anterioridade

Posterioridade 


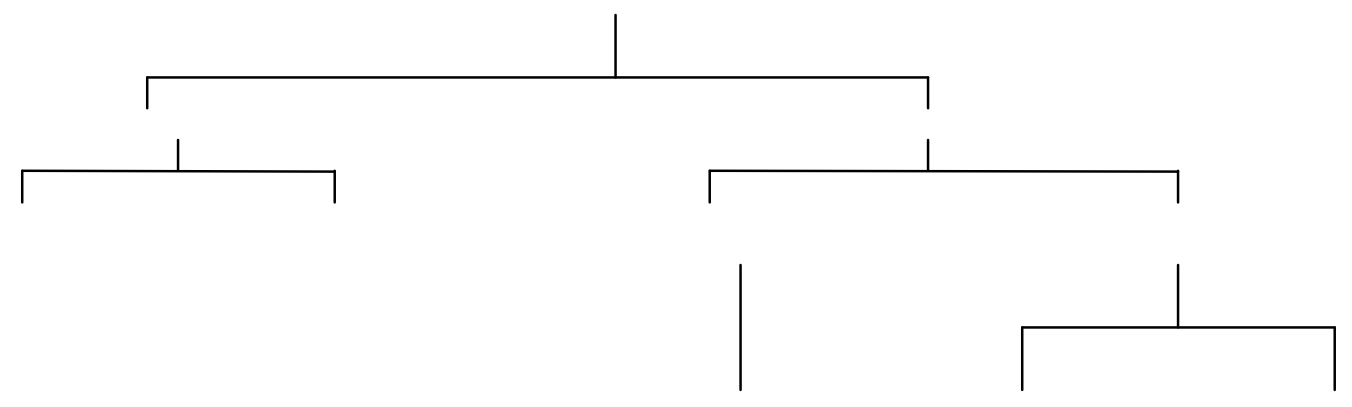

Quadro 5

Como já foi dito, o sistema enuncivo ordena os tempos verbais em dois subsistemas, um centrado no MR pretérito e outro centrado no MR futuro.

O subsistema organizado em torno do momento de referencia (MR) futuro apresenta o seguinte esquema:

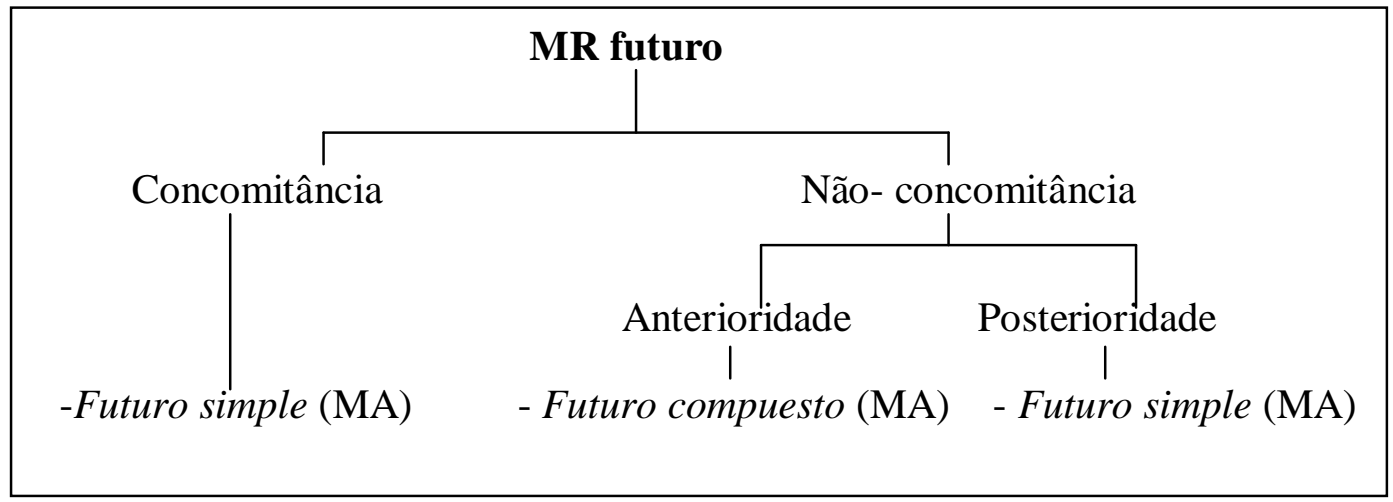

Quadro 6

\section{Concomitância}


A relação de concomitância entre o momento do acontecimento e o momento de referência futuro vem expressada pelo futuro simple. A posterioridade do momento de referência em relação ao momento da enunciação, no espanhol, exige um presente do subjuntivo na oração subordinada.

Aunque llueva saldré.

Cuando llegue te llamaré.

Em ambos os casos, as ações expressadas pelo futuro simple, saldre e llamaré, estão situadas em um momento futuro, posterior ao momento da enunciação, concomitantes ao momento de referência.

\section{Anterioridade}

A relação de anterioridade entre um momento de referência futuro e um acontecimento anterior é expressa no espanhol pelo futuro compuesto, denominado por Bello "ante-futuro". O momento de referência pode ser indicado por uma expressão temporal ou por um verbo no presente do subjuntivo em uma oração temporal.

Si no te das prisa, para cuando llegues ya habrá nacido el bebé.

En unos años, habrán construido la nueva línea de metro.

O momento do acontecimento expresso pelo futuro perfecto, habrá nacido e habrán construído, anterior ao momento de referência, no primeiro caso é expresso por uma oração temporal e no segundo, pela expressão de tempo en unos años.

\section{Posterioridade}


O futuro simple marca a relação de posterioridade do momento do acontecimento em relação ao momento de referência futuro. Um futuro está correlacionado a outro futuro ou ao presente de subjuntivo em orações temporais, e tal correlação vem apresentada, implícita ou explicitamente, por después ou advérbios similares.

Cuando llegues al bosque verás una cabaña, encima de la mesa encontrarás una llave, que abrirá la puerta de un jardín encantado.

\subsection{Os advérbios}

Os advérbios e as locuções de tempo também se articulam em um sistema enunciativo e outro enuncivo:

- sistema enunciativo, aquele que se centra em um MR presente concomitante ao ME;

- sistema enuncivo, aquele que se centra em um MR seja pretérito, seja futuro, inscrito no enunciado, não concomitante ao ME, que expressam a anterioridade e a posterioridade.

- O sistema enunciativo:

MR presente

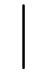

Concomitância

Não concomitância 


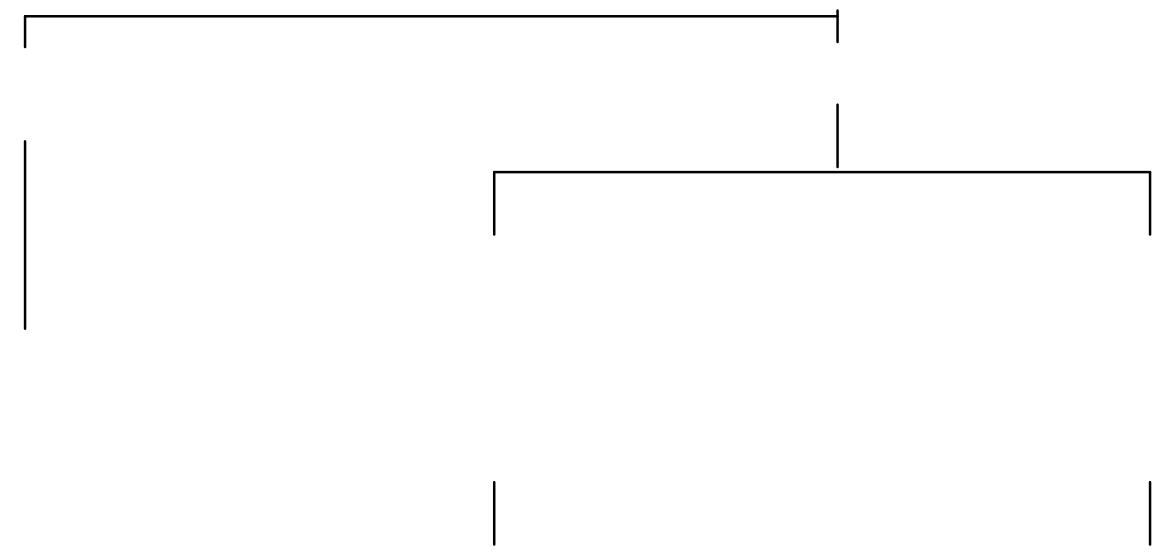

Quadro 7

Formas como hoy ou aquelas que se constroem com este + nome de divisão de tempo ou intervalo de tempo, neutralizam-se em relação à categoria topológica:

Hoy no tengo/ he tenido/ tenía/ tuve (em determinadas regiões)/ tendré hambre.

Este año es/ ha sido/ era/ será estupendo.

Acontece que tais intervalos de tempo podem ser subdivididos em intervalos menores, e esses intervalos menores são o momento de referência para o acontecimento. No primeiro exemplo, hoy é uma unidade de tempo que se subdivide de maneira que os acontecimentos são concomitantes, anteriores ou posteriores ao momento da enunciação, embora concomitantes em relação ao momento de referencia mais amplo.

Assim como em português, a expressão uno de estos(as) días/ semanas/ años... pode expressar tanto anterioridade quanto posterioridade enunciativas:

Uno de estos días nos encontraremos en algún lugar.

Se han visto uno de estos días y parece que han hecho las paces.

\section{- O sistema enuncivo}

\section{MR pretérito/ futuro}




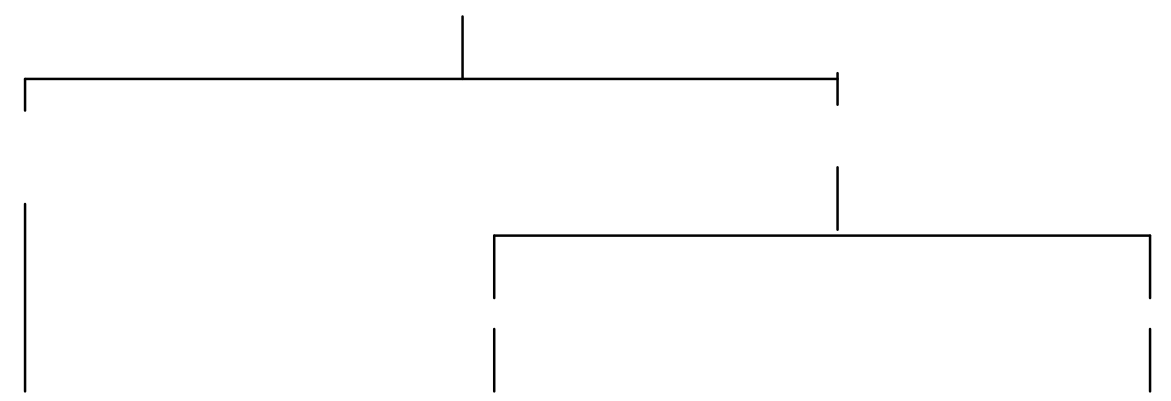

Quadro 8

A expressão algún ou otro día/ mes/ año... pode ter valor tanto enunciativo quanto enuncivo, e pode assinalar tanto anterioridade quanto posterioridade. Designam um ponto indeterminado no tempo.

Otro día iremos juntos al cine (posterioridade em relação ao MR presente).

Todos sabíamos que ese momento llegaría (posterioridade em relação ao MR pretérito).

Ya habíamos hablado con él el otro día, cuando nos contaron lo sucedido (anterioridade en relação ao MR pretérito).

É importante notar a diferença entre o sistema enunciativo e o sistema enuncivo.

- Hoy estoy resfriada, con la lluvia de ayer me empape, mañana estaré mejor.

- Aquel día estaba resfriada, me había empapado con la lluvia del día anterior, al día siguiente estaría mejor.

No primeiro exemplo, o momento da enunciação coincide com o momento de referência, pertence a um sistema enunciativo. Já no segundo caso, o momento de referencia instaura-se no enunciado e o momento de referência é anterior à enunciação, assim é preciso mudar os advérbios para deixar claro o sentido. 
Os advérbios de tempo organizam-se, como já foi visto, em dois sistemas, enunciativo e enuncivo, mas, a diferença do sistema verbal, o sistema enuncivo não está subdividido. Os advérbios e locuções do sistema enuncivo remetem tanto ao momento de referência pretérito quanto ao futuro.

Le llamé unos días antes de ingresar en el hospital.

Le llamaré unos días antes de ingresar en el hospital.

No primeiro exemplo, o marco temporal instaurado no enunciado, unos días antes, indica a concomitância com a anterioridade, no segundo caso, a concomitância com a posterioridade.

O sistema adverbial, assim como o sistema verbal, apresenta também advérbios de aspecto que denotam:

- $\quad$ aspecto pontual: de repente, de sopetón, repentinamente, súbitamente, en un abrir y cerrar de ojos, deprisa, inmediatamente, a quema ropa, etc.;

- aspecto durativo continuo: por mucho tiempo, paulatinamente, sin cesar, continuamente, etc. Pode aparecer o aspecto progressivo para indicar o desenrolar paulatino de uma ação, como: poco a poco, progresivamente, gradualmente, paulatinamente, etc.;

- aspecto durativo iterativo: habitualmente, constantemente, normalmente, regularmente, de vez en cuando, a veces, en algunas ocasiones, de nuevo, una vez más, etc.;

Os advérbios pontuais, semelhante ao que acontece no português, servem para indicar a ruptura, a descontinuidade que irrompe na continuidade, de um estado marcado pelo imperfecto e os advérbios durativos, para dar começo às transformações, marcadas pelo pretérito perfecto simple. 
O advérbio siempre pode apresentar aspecto contínuo ou iterativo:

Los primeros meses siempre hay que estar pendientes de ellos.

Siempre va dos veces por semana a la biblioteca.

O advérbio nunca nega os de tempo ou de aspecto. Pode aparecer reforçado pela expressão en mi/la vida, ou aparecer simplesmente mencionado.

Nunca en su vida había presenciado prodigio tal.

En su vida había visto tal cosa.

Os advérbios de seqüencialização são específicos para marcar a sucessão de estados e transformações. Dividem-se em três grupos que indicam:

- concomitância: en ese tiempo, entretanto, entonces;

- anterioridade: antes, mucho antes, con anterioridad;

- posterioridade: después, poco/mucho después, más tarde, posteriormente.

Esses advérbios determinam a seqüência das funções narrativas, instituindo uma ligação entre elas.

Poco antes de nacer, su padre fue llamado a filas, entonces estalló la guerra, mucho tiempo después recordaría su llegada, tras duros años en el frente.

Uma sequiência de ações pode ser considerada um processo e como tal uma série de advérbios marcam seu inicio e seu fim :

- Advérbios incoativos: al principio, primero, para empezar/comenzar, inicialmente.

- Adverbios terminativos: al final, por último/ fin, para acabar/ finalizar/ terminar. 
Había una vez una Rana que quería ser una Rana auténtica, y todos los días se esforzaba en ello.

Al principio se compró un espejo en el que se miraba largamente buscando su ansiada autenticidad.

Unas veces parecía encontrarla y otras no, según el humor de ese día o de esa hora, hasta que se cansó de esto y guardó el espejo en un baúl.

Por fin pensó que la única forma de conocer su propio valor estaba en la opinión de la gente, $[\ldots]^{40}$.

Aprecia-se no exemplo mencionado a progressão temporal marcada pelos advérbios, desde o começo (al principio) até o fim (por fin). A ação manifesta a concomitância com o momento de referência anterior ao momento da enunciação.

Dois casos interessantes são os advérbios ya e todavíal aún, contrários entre si, a negação de um implica a afirmação do outro:

- Todavíal aún contem traços de anterioridade, concomitância e sentido de inacabado

Después de tantos problemas todavía están casados.

O fato de estar casados marca a anterioridade porque aconteceu antes da enunciação, por outro lado é concomitante porque no momento de referência continuam casados e é inacabado porque não se efetuou a separação, mesmo com problemas no relacionamento.

- $Y a$ contem traços de posterioridade, concomitância e sentido de acabado.

Hubo una vez un rayo que cayó dos veces en el mismo sitio; pero encontró que ya la primera había hecho suficiente daño, que ya no era necesario, y se deprimió mucho ${ }^{41}$.

${ }^{40}$ MONTERROSO, Augusto (1991). La Oveja negra y demás fábulas. Barcelona: Anagrama (p.53). 
A posteridade expressa pelo advérbio ya é pressuposta, ou seja, no texto, depois do primeiro raio. Acompanha um ato que é concomitante e acabado em relação ao momento de referência.

\subsection{As preposições}

Da mesma forma que é possível organizar os advérbios, a categoria topológica concomitância vs não concomitância (anterioridade vs posterioridade) organiza as preposições e as locuções prepositivas. À diferença do que acontecia com os advérbios, a categoria topológica não se desdobra em sistema enuncivo e sistema enunciativo para organizar as preposições.

- A continuidade é expressa por: durante, a lo largo de, en el momento de, en la época de.

- A anterioridade é expressa por: antes de.

- A posterioridade é expressa por: después, trás.

Considerando o aspecto é possível organizar as preposições segundo: pontual vs durativo (incoativo vs terminativo).

- Desde, a partir de expressam um valor durativo-incoativo, ou seja, apresentam o momento em que a ação começou no tempo, desde um ponto

${ }^{41}$ MONTERROSO, Augusto (1991). La Oveja negra y demás fábulas. Barcelona: Anagrama. (p.39). 
de vista restrospectivo, e indicam que ele dura no tempo, mas sem valor algum prospectivo.

- Hasta expressa um valor durativo-terminativo. Mostra o ponto final de uma ação que dura no tempo. Normalmente aparece com outras preposições ou advérbios para expressar o fim.

- De... a/ hasta, desde... hasta, a partir de...hasta indicam o inicio e o fim da seqüência.

\subsection{As conjunções}

As conjunções ou locuções conjuntivas temporais organizam-se em torno da categoria topológica concomitância vs não concomitância (anterioridade vs posterioridade) sem distinguir entre um sistema enunciativo e um enuncivo.

- Concomitância: uma ação desenvolve-se ao mesmo tempo que a outra, remetem ao mesmo momento de referência. Os nexos mais adequados são: mientras, a medida que, cuando, al tiempo que, según, al par que, conforme, a la vez que, siempre que, cada vez que, todas las veces que. Essas três últimas com caráter iterativo.

- Anterioridade: uma ação acontece antes que a outra. Os nexos são: cuando, tan pronto como, así que, nada más que, una vez que, no bien, apenas, en cuanto, antes de que.

Na maioria dos casos a anterioridade expressa é de caráter imediato.

- Posterioridade: empregam-se nexos como: después de que, cuando. 
Por outro lado o aspecto incoativo vem marcado pelo nexo desde que e o terminativo por hasta que. ${ }^{42}$

\subsection{Pretérito perfecto simple e pretérito perfecto compuesto}

Ao organizar o sistema temporal do espanhol, o estudioso defronta-se com o problema de estudar as relações que alguns tempos verbais mantêm entre eles dentro do discurso e a posição que ocupam em função do momento da enunciação, segundo alguns, ou a respeito de um ponto chamado origen, segundo outros. Estudaremos aqui as relações que o pretérito perfecto compuesto e o pretérito perfecto simple estabelecem entre eles, assim como a posição que ocupam dentro do esquema que organiza o sistema temporal do espanhol considerando a opinião de vários autores.

Recapitulemos a teoria que fundamenta este trabalho. Dois momentos são instaurados pelo discurso, um momento que resulta contemporâneo ao ato da enunciação, o agora, e outro momento que não é contemporâneo, o então. Portanto o presente é o momento contemporâneo ao ato da enunciação. Lembre-se que o presente aparece como tempo lingüístico, tempo do discurso, e não como tempo cronológico, reinventando-se em cada ato de comunicação, em cada momento de enunciação. O presente cria um eixo topológico que organiza os tempos do sistema em função de um momento de referência presente concomitante ao momento da enunciação, no qual o narrado é simultâneo à narração, e de momentos de referencia não-concomitantes ao momento da enunciação. Os momentos não-concomitantes com a enunciação resultam em um momento de referência anterior à enunciação e outro posterior à enunciação, representados pela oposição anterioridade vs posterioridade.

${ }^{42}$ Classificação de Gómez Torrego em: GÓMEZ TORREGO, Leonardo (2002) Gramática didáctica del español. Madrid: Ediciones SM (p. 346). 
Por sua vez, cada momento do acontecimento ordena-se em função do momento de referência correspondente, e aplica-se a eles a categoria topológica concomitância vs nãoconcomitância (anterioridade vs posterioridade). Desta maneira todos os tempos do sistema, expressem relações de anterioridade, de posterioridade ou de concomitância, estão relacionados com a enunciação (ver quadro 1) e estruturados em função de três momentos, momento da enunciação, momento de referência e momento do acontecimento. Os tempos utilizados para expressar a concomitância conformam o sistema enunciativo e os tempos que expressam a não-concomitância organizam-se no sistema enuncivo. Nesse caso, a anterioridade ou a posterioridade deverá ser sempre explicitada.

Por outro lado, os advérbios também se organizam conforme esses parâmetros, de maneira que existem advérbios que expressam a relação de concomitância com o momento da enunciação, ou seja, o momento de referência inclui o momento da enunciação e, paralelamente, há os advérbios que exprimem a relação de não-concomitância. Deparamonos com um sistema enunciativo e com um sistema enuncivo para a organização dos advérbios. No entanto, no caso dos advérbios, unicamente o sistema enunciativo expressa três momentos do acontecimento, pois desde o momento que se diz hoy, para expressar a concomitância com o momento de referência presente, remete-se a um ayer, a anterioridade da concomitância, e a um mañana, a posterioridade da concomitância. Já no sistema enuncivo, a anterioridade é expressa pelo entonces e a posterioridade pelo después (ver quadro 7).

Do ponto de vista da teoria apresentada o pretérito perfecto simple (compré) expressa a relação da concomitância da anterioridade e o pretérito perfecto compuesto (he comprado) exprime a relação de anterioridade da concomitância, pertencendo o primeiro ao sistema enuncivo e o segundo a o sistema enunciativo (ver quadro 4).

1) He comprado el pan

2) Compré el pan

Em 1) estamos no sistema enunciativo, momento de referencia presente, concomitante com o momento da enunciação, e momento do acontecimento anterior a ele. Já em 2) o verbo expressa um acontecimento simultâneo, concomitante, a um momento 
anterior ao momento da enunciação, o momento do acontecimento deverá ser explicitado, ancorado, no enuncido.

Como já foi colocado neste trabalho, Andrés Bello (Bello,1984) vê claramente a relação que existe entre o pretérito perfecto compuesto (he comprado) e o presente, já desde a denominação que ele emprega para esse tempo ante-presente. É a forma que tem relação com algo que ainda existe no presente ou cujas consequiências ou efeitos perduram no momento da enunciação. Já o pretérito perfecto simple (compré), por ele denominado simplesmente pretérito, significa a anterioridade do atributo ao ato da palavra (Bello,1984, p. 200). Bello já apontou que as formas verbais representam diferentes tipos de relações, umas simples, como é o caso do pretérito, e outras duplas, como é o caso do antepretérito, e até triplas, por exemplo o ante-pos-pretérito (habría comprado).

Do ponto de vista histórico, Guillermo Rojo e Alexandre Veiga na Gramática Descriptiva de la Lengua Española (p. 2944) explicam como a forma do pretérito perfecto simple (canté) é herdeira direta do perfeito latino (cantavi>canté). O valor que essa forma reunia era tanto o valor do pretérito quanto o valor do ante-pretérito do espanhol, ou seja, no latim era usado para expressar ações perfeitas, pontuais, simplesmente anteriores ao momento da fala. A construção com haber, indicam os autores, é uma criação romance, ou seja, do latim vulgar habeo factum, que expressava uma ação passada, acabada que permanecia no presente. Só a partir da época clássica, continuam os autores, começa a expressar uma ação concluída imediatamente anterior ao presente, cujo resultado tem importância para o falante no momento da palavra.

Como resultado da situação histórica descrita, os autores estabelecem as seguintes semelhanças e diferenças entre o pretérito e o ante-presente, ou seja entre o pretérito perfecto simple e o pretérito perfecto compuesto:

- Ambos indicam uma relação de anterioridade a respeito do momento da fala e ambos indicam ações perfeitas, concluídas antes do momento da fala. 
- A forma simples expressa só anterioridade a respeito do momento da fala, criando um âmbito próprio no passado diferente do momento da fala. A forma composta indica anterioridade dentro do âmbito do presente, mantendo relação com a atualidade do falante (Rojo e Veiga, 1999, p.2945)

Guillermo Rojo e Alexandre Veiga, na Gramática Descriptiva de la Lengua Española (1999: 2900), explicam que as três realizações temporais básicas, consistentes numa orientação medida diretamente desde o ponto de origem, normalmente considerada a enunciação, mas que nem sempre é, são as formas canté, canto e cantaré. Segundo a orientação temporal primária, diretamente focada desde o centro de referência do sistema, o presente expressa a simultaneidade em relação à origem $(\mathrm{OoV})$, o pretérito expressa a anterioridade $(\mathrm{O}-\mathrm{V})$ e o futuro a posterioridade $(\mathrm{O}+\mathrm{V})$. A partir dessas relações básicas primárias organiza-se o sistema verbal do espanhol, estabelecendo relações de anterioridade, simultaneidade ou posterioridade em relação a elas. Assim, por exemplo, o imperfecto expressa uma relação de simultaneidade em relação a um momento anterior à origem (O-V)oV (Rojo, 1990: 29).

No caso específico do pretérito, para ambos autores (Gramática Descriptiva, 1999, p. 2901), o fato de aparecer com diferentes expressões de tempo não afeta a interpretação da relação temporal expressa pelo tempo verbal. Segundo os autores, nos seguintes exemplos a relação temporal expressa pelo verbo é exatamente a mesma, pretérito.
a. Me lo dijeron ayer.
b. Me lo dijeron hace dos semanas
c. Me lo dijeron hace varios años.
d. Me lo dijeron antes de cumplir dos años.
e. Me lo dijeron después de cumplir los diez años.

E continuam explicando que a distância cronológica do processo expresso pelo verbo dijeron, do ponto de vista gramatical, carece de relevância. Embora as expressões temporais adicionem algum tipo de precisão, não constituem pontos de referência para a orientação temporal. 
Pensemos esses exemplos desde o ponto de vista da teoria de Fiorin (2001). Para começar defrontamo-nos com um obstáculo. Nos exemplos a., b., c., as expressões de tempo utilizadas expressam a relação de anterioridade da concomitância pertencente a um sistema enunciativo, enquanto que o tempo utilizado, pretérito perfecto simple, é o tempo que expressa a relação de concomitância com a anterioridade no sistema enuncivo. Já nos exemplos d., e., tanto o verbo quanto as expressões de tempo pertencem ao sistema enuncivo. Poderíamos pensar que nos três primeiros exemplos trata-se de uma embreagem adverbial. Lembremos como Fiorin (2001: 191) define a embreagem segundo Greimas e Courtès:

[...] a embreagem temporal é "o efeito de retorno à instância da enunciação, produzido pela suspensão da oposição entre certos termos" da categoria de tempo (Greimas e Courtès, 1979: 119).

A debreagem cria uma enunciação enunciada, em que os tempos do enunciado simulam os tempos da enunciação; ou um enunciado enunciado, em que se tem a ilusão de estar diante da temporalidade dos acontecimentos, e de estar sempre em presença de uma temporalidade não-linguística: tempo do ato de dizer, no primeiro caso; tempo dos eventos, no segundo. A embreagem acontece quando se neutralizam termos da categoria de tempo e se criam efeitos de sentido como presentificar o passado (Fiorin, 2001: 191). Quando ocorre uma embreagem temporal deve haver uma marca temporal no contexto que permita dizer que um verbo ou um advérbio estão sendo usados com o valor do outro (Fiorin, 2001: 193).

Acontece, no entanto, que o pretérito perfecto simple (canté) aparece regularmente, salvo em algumas variantes regionais, com os advérbios e expressões temporais que exprimem a anterioridade da concomitância, sem ocorrer nenhum tipo de embreagem, já que não é o caso de ser usado com valor de outro. Da mesma forma acontece com as expressões de tempo. Coerentemente com a descrição exposta do funcionamento do sistema verbal no espanhol segundo a teoria proposta por Fiorin, deveria considera-se a 
possibilidade de que o pretérito perfecto simple (canté) também pudesse expressar a anterioridade da concomitância formando parte do sistema enunciativo.

Examinemos um exemplo que apresentado por Guillermo Rojo e Alexandre Veiga (1999: 2907)

Cerraron la campana ayer, descansan hoy y votarán mañana.

Do ponto de vista dos autores, os verbos cerraron, descansan, votarán, pretérito perfecto simple, presente e futuro simple do indicativo respectivamente, expressam orientações temporais primárias em relação ao ponto de origem, relações monovectoriais. Enquanto que analisando-as do ponto de vista do esquema apresentado por Fiorin, poderiase considerar que cerraron junto do advérbio ayer expressa a anterioridade da concomitância com um momento de referência presente, simultâneo ao momento da enunciação; descansan junto do advérbio hoy expressa a concomitância da concomitância com um momento de referência presente, simultâneo ao momento da enunciação; votarán junto do advérbio mañana expressa a posteridade da concomitância com um momento de referência presente, simultâneo ao momento da enunciação, mostrando os três como funciona o sistema enunciativo. Ou seja, o discurso criaria uma enunciação enunciada que refletiria o tempo do ato de dizer.

Os autores citados negam a importância de determinados advérbios de tempo para precisar a relação temporal a respeito da enunciação. Consideram que as três realizações básicas não variam em função da amplitude das referências temporais, denotem elas processos pontuais ou gerais, de duração breve ou ampla. A teoria de Fiorin, adotada no presente trabalho, estaria mais próxima da teoria de Pena, referida em uma nota de rodapé em outro trabalho de Guillermo Rojo ${ }^{43}$, na qual Rojo (Rojo, 1990: 26) cita Pena que afirma que a temporalidade "caracteriza a la base de la predicación nuclear del enunciado [...] com referência al acto de enunciar" e reconhece que "el punto de referência no tiene por qué estar necesariamente en la enunciación; puede estar dentro del enunciado". A teoria de

\footnotetext{
${ }^{43}$ ROJO, Guillermo (1990). "Relaciones entre temporalidad y aspecto em el verbo em español” em Tiempo y aspecto em Español. Ignácio Bosque (ed.). Madrid: Cátedra.
} 
Fiorin aproxima-se da afirmação de Pena ao diferenciar entre enunciação enunciada e enunciado enunciado.

Este trabalho aponta a possibilidade de considerar que para expressar a anterioridade da concomitância poderiam ser usados dois tempos, pretérito perfecto compuesto (ha cantado) e pretérito perfecto simple (canto), sempre que acompanhado esse último por expressões temporais do sisitema enunciativo que marquem a anterioridade da concomitância (ayer, la semana pasada, hace unos días ...).

A diferença crucial entre ambos os tempos é determinada pelo próprio sentido de cada um deles. O pretérito perfecto compuesto (ha cantado) possui o valor de antepresente, como Bello já apontou. É um tempo cuja diferença com o presente se encontra no fato de expressar uma ação anterior, perfectiva, cujos efeitos e/ou conseqüências chegam até o momento da enunciação. Usado com advérbios que expressam a concomitância da concomitância no sistema enunciativo, eles sofrem uma embreagem ou dislocación, termo empregado por Rojo e Veiga para denominar este fenômeno, passando a expressar a anterioridade da concomitância.

1. Esta semana es crucial.

2. Esta semana ha sido crucial.

Não há dúvida que em 1. estamos ainda vivenciando esse período de tempo e o que tiver que acontecer de relevante ainda não foi concluído. Já em 2., mesmo nos encontrando no final do período de tempo, que pode não ter finalizado, os fatos que deram relevância à semana já aconteceram. A denominação de ante-presente não só implica que se expressem ações, acontecimentos, imediatamente anteriores ao momento de referência presente, no sentido que a expressão de tempo pode ser ampla (este siglo, este año, por exemplo), e sim que os efeitos perduram no momento de referência presente, concomitante com o momento da enunciação. 
Já no caso do pretérito perfecto simple, denominado por Bello pretérito, o valor intrínseco do tempo é de uma ação anterior concluída, pontual, perfectivo, não interessam os efeitos no momento presente. No entanto, esse acontecimento pode ser situado em dois momentos de referência diferentes a respeito da enunciação. $O$ fato de ser um tempo que responde à descrição de acabado, pontual, dinâmico, limitado, pode criar no enunciador um efeito de distanciamento do momento de referência concomitante à enunciação.

1. El año pasado se fue de vacaciones a Marruecos.

2. Ayer se fue de vaciones a Marruecos.

3. Se fue de vaciones a Marruecos.

Nos exemplos 1. e 2. a diferente amplitude da expressão de tempo poderia levar a pensar que estamos diante de duas posições diferentes a respeito do momento da enunciação, mas as referências temporais instauram a o tempo como anterior à concomitância com o momento da enunciação. Só é fatível dizer ayer e el año pasado desde a enunciação, o narrado coincide com a narração. No exemplo 3. o momento de referência temporal está no enunciado. Esse enunciado precisaria de uma referência temporal, ser ancorado, para se saber quando aconteceu. Desde o eixo temporal do agora da enunciação instaura, estamos diante de um momento anterior a enunciação, o então. Nesse último caso o enunciado apresenta-se como simplesmente informativo.

\section{Se ha ido de vacaciones a Marruecos esta semana.}

No exemplo 4. o tempo verbal indica que é um momento anterior á própria enunciação por coincidir o momento de referência com momento da enunciação. Comparando 1. e 2. com 4., os primeiros não deixam de ter o valor de anterioridade que todos os estúdios atribuem ao pretérito perfecto simple, mas é uma anterioridade em referência ao momento em que se produz a enunciação desse acontecimento, cujos efeitos ou conseqüências não interessam, marcada por uma expressão de tempo concluído. Já no exemplo 4. o uso do pretérito perfecto compuesto expressa a anterioridade do acontecimento a respeito do momento em que se enuncia, marcada com uma expressão de 
tempo não concluído que o aproxima mais do presente porque os efeitos dessa viagem estão de certa maneira latentes.

Poderia-se, então, considerar a possibilidade de usar do pretérito perfecto simple para expressar a anterioridade de um momento de referência simultâneo ao momento da enunciação sempre que for usado com expressões de tempo que delimitem essa posição no esquema proposto neste trabalho.

\section{O tempo no discurso referido}

Neste capítulo serão definidos o discurso direto e o discurso indireto por autores não pertencentes ao âmbito da semiótica para, assim, estabelecer uma comparação com os procedimentos semióticos apresentados por Fiorin (2000). Serão situados, tanto o discurso direto quanto o discurso indireto, como discursos citados e se apresentarão os tradicionais esquemas dos câmbios ocorrentes na passagem do discurso direto para o discurso indireto.

Um objeto ou um estado de coisas da realidade pode ser representado por meio do discurso, segundo Graciela Reyes (Reyes, 1995: 10)*. Supondo que alguém pronuncia como verdadeiros os seguintes enunciados:

\footnotetext{
* A idéia de relacionar as palavras com as coisas do mundo não pertence à teoria saussuriana, pois para Saussure o signo lingüístico ganha valor na relação com outros signos lingüísticos. Graciela Reyes se afasta dessa teoria neste parágrafo, enquanto a teoria semiótica adotada ao longo deste trabalho recolhe a teoria
} 
El profesor tenía mala cara

La primavera ha llegado

são orações pronunciadas ou escritas por alguém que quer se comunicar com outra pessoa, são orações que dão ao interlocutor informações, que afirmam algo sobre a verdade.

O discurso também pode ser usado para se reproduzir um objeto da mesma natureza: outro discurso (Reyes, 1995: 10). É o que acontece quando alguém reproduz ou finge que reproduz literalmente as palavras de outro:

Manuela grito: !no te aguanto más!

Ou quando se cita, a reprodução do que outro diz sem imitar as palavras exatas, como no exemplo a seguir:

El niño pidió chocolate a su madre.

Estamos diante dos mecanismos de citação mais freqüentes que aparecem nos textos de estilo direto, no primeiro exemplo, e de estilo indireto, no segundo exemplo. Reyes, define a citação como (Reyes, 1995: 7) o ato de reproduzir outro discurso, ou um aspecto ou parte de outro discurso, no próprio. O texto citado muda de lugar, passa do contexto em que foi enunciado para o contexto no qual se reproduz. Citar é construir uma representação de palavras alheias, transpondo-as de um lugar para outro, ou seja, de um discurso para outro. A possibilidade de se reproduzir um discurso é um universal da linguagem (Maldonado, 1999: 3551). Em todas as línguas o fato de poder reproduzir um discurso é um fenômeno diferente ao de produzir o discurso de forma original, seja com as próprias palavras, seja referindo-se a ela, como já foi exemplificado.

saussuriana. Assim, como será explicado, as transposições de pessoa, espaço e tempo ocorridas na passagem do discurso direto para o discurso indireto, ou vice-versa, dependerão da relação dos elementos do discurso e não do contexto fora de ele. O texto de Graciela Reyes serve como base de comparação das duas teorias. 
Mesmo considerando a existência de vários mecanismos de reprodução do discurso, os dois de uso mais geral, como já foi colocado, são o discurso direto e o discurso indireto;

- Discurso direto: constituído por uma expressão que o introduz, em que aparece o verbo "dizer" flexionado, separada por uma pausa, marcada tipograficamente por dois pontos, da citação. Essa, marcada tipograficamente pelas aspas ou pelo travessão, é a reprodução literal de um enunciado.

- Discurso indireto: constituído por uma expressão que o introduz, em que aparece o verbo "dizer" flexionado, e uma citação indireta, marcada pela conjunção que, subordinada ao verbo da expressão que a introduz. (Maldonado, 1999: 3554).

Considera-se também uma outra definição de discurso direto e discurso indireto (Reyes, 1995: 13). Observando os exemplos anteriores, o DD (discurso direto) é uma reconstrução de um discurso, enquanto o DI (discurso indireto) é uma paráfrase, mais ou menos livre, de um discurso. No DD permanecem as estruturas dêiticas (pronomes, verbos e advérbios de tempo e lugar) do falante original, o citado, enquanto no DI essas referências acomodam-se ao falante que cita:

\section{[...] Querida Milagros, \\ llevo tres días aquí, \\ te echo de menos, no puedo \\ vivir sin ti.}

Se Milagros, a quem parece que a carta representada nessa música é remetida, fosse reproduzir o conteúdo da mesma:

Adrián (me) dice que lleva tres días allí, que me echa de menos y que no puede vivir sin mi.

Adrián (me) dijo que llevaba tres días allí, que me echaba de menos y que no podía vivir sin mí. 
No primeiro exemplo, ao ser o falante o centro do seu próprio sistema dêitico o sistema esta organizado em função do eu-aqui-agora del ele. O DD permite a reconstrução de um momento de enunciação com seus próprios eu-aqui-agora. Na reprodução do discurso de maneira indireta, o sistema dêitico muda o centro de referência, os pronomes de primeira pessoa, por exemplo, referem-se ao enunciador que está falando e se o momento da enunciação sofre alterações os tempos verbais vão refletir isso.

A seguir serão colocados os requisitos discursivos que um enunciado lingüístico precisa cumprir para ser reconhecido como discurso reproduzido: (Maldonado, 1999: 3555)

1. Em uma situação de enunciação $E$, entendida como o ato em que o falante emite um enunciado em um momento e lugar determinado, dirigido para um ou vários destinatários, o objeto de $E$ há de ser outra situação de enunciação $E_{j}$, a qual vai ser reproduzida. Não é relevante se o discurso reproduzido corresponde às palavras emitidas ou não. $\mathrm{Na}$ verdade, o discurso reproduzido, seja real ou imaginário, precisa da reconstrução de sua situação de enunciação correspondente.

O DD é real quando as palavras atribuídas ao falante original são idênticas àquelas que ele falou. O DI é real quando o conteúdo das palavras atribuídas ao falante original é igual ao das palavras que ele falou.

2. Dentro da cadeia verbal deve estar representado o objeto da situação de enunciação $E_{j}$. É precisão, então, distinguir entre "discurso reproduzido" e "discurso referido". O primeiro reproduz uma situação de enunciação (enunciado original, falante e destinatário da mensagem, onde e quando aconteceu a produção original do enunciado). Enquanto o segundo só descreve uma ação realizada verbalmente. Os exemplos que Maldonado coloca (Maldonado, 1999: 3557) são:

a) Gritó 
b) Me gritó que me marchara

Os "verbos de maneira de dizer" sem nenhum complemento explícito não podem ser considerados verbos de citação (a), é preciso que a eles siga o complemento (b).

3. O verbo que introduz a citação não pode ser usado com valor realizativo, ou seja, não pode aparecer no presente e em primeira pessoa porque isso supõe a sua realização e não uma simples descrição. Em contextos nos quais o presente morfológico coincide com o presente real, momento da enunciação, é possível que aconteça o DD e o DI.

Concluindo, se bem que o fato de que parte do discurso possa ser reproduzido pelo próprio discurso é um universal, como já foi dito, cada língua pode variar na forma em que isso acontece. No entanto, devem ser cumpridos os mesmos requisitos para se poder considerar que existe um discurso reproduzido: que o discurso proceda duma situação de comunicação, e que portanto apareça introduzido por verbos usados de forma descritiva e não realizativa, e que a situação de enunciação reprodutora tenha como objeto a situação de enunciação reproduzida (Maldonado, 1999: 3558).

Os chamados verbum discendi são os verbos que expressam as atividades verbais realizadas com a intenção de se comunicar algo. Os traços semânticos comuns a todos eles seriam: o referente do sujeito e do objeto indireto são tipicamente humanos, ou personificados, é o caso das fábulas, e são verbos ativos, que não pressupõem a verdade de seus complementos.

A seguir alguns dos verbum discendi que podem aparecer tanto no DD quanto no DI (Maldonado, 1999: 3562):

- Verbos de opinião: opinar, considerar, reputar, juzgar, etc

- Verbos de valoração positiva: alabar, aplaudir, aprobar, celebrar, elogiar, felicitar, etc 
- Verbos de valoração negativa: criticar, reprochar, etc.

- Verbos declarativos: decir, comunicar, mencionar, notificar, manifestar, responder, contestar, etc.

- Verbos de maneira de dizer: gemir, gritar, susurrar, chillar, balbucear, murmurar, etc.

- Verbos que expressam a modalidade da enunciação: exclamar, preguntar, etc.

- Verbos de petição: rogar, pedir, suplicar, exigir, solicitar, reclamar, etc.

- Verbos declarativos com valor prospectivo: anunciar, pronosticar, augurar, predecir, prometer, jurar, avisar, etc.

- Verbos de pensamento e percepção, que a diferença dos verbos de comunicação não se constroem com complemento indireto, mas que transmitem, verbalizando-os, o conteúdo do pensamento e da percepção: pensar, sentir, creer, etc.

\section{A sintaxe do DD}

No discurso direto, o marco da citação e a citação aparecem em relação assindética, justapostas. A citação diferencia-se do marco pela entonação e pelas pausas, usando-se aspas ou travessão.

“¡Es verdad! ¡Han venido a buscarte!”, exclamó de repente Adela, que había oído las últimas palabras de Lubis $^{44}$.

O marco da citação está formado por um verbo de comunicação que pode ir anteposto ou posposto à citação que aparece sempre entre aspas ou travessão.

A característica mais importante do discurso direto é que conserva o sistema dêitico original. As expressões dêiticas são aquelas que remetem ao falante, ao interlocutor, ao tempo e ao espaço no qual acontece a enunciação:

\footnotetext{
${ }^{44}$ ATXAGA, Bernardo (2004). El hijo del acordeonista. Madrid,: Alfaguara, (p. 226).
} 
- Pronomes pessoais

- Pronomes demonstrativos

- Tempos verbais

- Advérbios

O ponto de referência para o sistema dêitico é o momento da fala (Reyes, 1995: 13): presente (tempo), lugar presente (espaço), o falante e o ouvinte (pessoa). O significado dos dêiticos varia conforme a pessoa que fala, o momento e o lugar da fala. Como os referentes dos dêiticos estão fora do texto é preciso conhecer a situação extralingüística para realizar a interpretação adequada. O falante é o centro do seu próprio sistema dêitico, e seu discurso está organizado a partir desse centro formado por yo-aquí-ahora (Reyes, 1995: 14).

El trompetista de la orquestina anunció por el micrófono una canción clásica: "Y ahora para todos ustedes Quinientas millas". "Me gusta mucho. Tiene uma melodía muy bonita”, dijo Virginia ${ }^{45}$

O narrador, neste caso o falante citador, uma das personagens, repete as palavras de Virginia sem assumi-las, como se simplesmente fosse um ator que faz uso da primeira pessoa “me gusta mucho", está ausente. Segundo Reyes, é possível dizer "yo” sem referirse a si próprio. O DD é a reconstrução de uma situação de enunciação com seus próprios yo, tú, aquí, ahora (Reyes, 1995: 14).

\section{Estrutura sintática do DI}

Segundo Graciela Reyes (Reyes, 1995: 31) as orações que possuem uma citação indireta estão conformadas por um verbo de comunicação verbal e uma oração subordinada introduzida por que; as orações interrogativas indiretas totais aparecem introduzidas por si (ou por que si), e as interrogativas parciais por um pronome interrogativo (ou por que + pronome). A função sintática da citação é o complemento direto do verbo que a introduz.

\footnotetext{
${ }^{45}$ ATXAGA, Bernardo (2004). El hijo del acordeonista. Madrid: Alfaguara, (p. 370).
} 
El médico me preguntó (que) cuántas horas dormía por día.

El médico me preguntó (que) si creía eso suficiente.

El médico me dijo que debía dormir más.

Como já foi explicado, no DD o falante imita, ou faz como se imitasse, o que outro falante ou ele mesmo diz, e o segmento em que isso acontece fica isolado sintaticamente (dois pontos, aspas, travessão). Muito pelo contrário, o DI é a fusão de vozes e a concomitância da subordinação sintática (Reyes, 1995: 34).

Pensemos no seguinte exemplo:

a) "Siempre me ha gustado el nombre que diste a mis labios", ha dicho, y me ha vuelto a dar un beso. Mary Ann me rescata siempre. Antes me ayudó a libertarme del pasado; ahora me quita el miedo al futuro ${ }^{46}$.

b) Ha dicho que siempre le ha gustado el nombre que di a sus labios, y me ha vuelto a dar un beso. Mary Ann me rescata siempre. Antes me ayudó a libertarme del pasado; ahora me quita el miedo al futuro.

Segundo a explicação de Graciela Reyes (1995: 34) no primeiro caso (a) estamos diante de um enunciado constituído por duas orações justapostas, já no segundo (b) são duas orações, uma principal e outra subordinada unidas pela conjunção que. Em (a) aparece a instância do discurso da personagem, neste caso de Mary Ann; no segundo (b) o narrador fala para o leitor desse discurso. Os centros dêiticos dos que fala Reyes são diferentes, enquanto em (a) a dêixis se organiza em função do yo-ahora da personagem Mary Ann, em (b) a dêixis se organiza a partir do yo-ahora do locutor, ou seja do narrador. Portanto os pronomes vão mudar de posição, a primeira pessoa de (a) vai passar para terceira pessoa em

\footnotetext{
${ }^{46}$ ATXAGA, Bernardo (2004). El hijo del acordeonista. Madrid: Alfaguara (p. 405).
} 
(b) e a segunda pessoa de (a) vai mudar para primeira pessoa em (b). neste caso o verbo não sofre alteração.

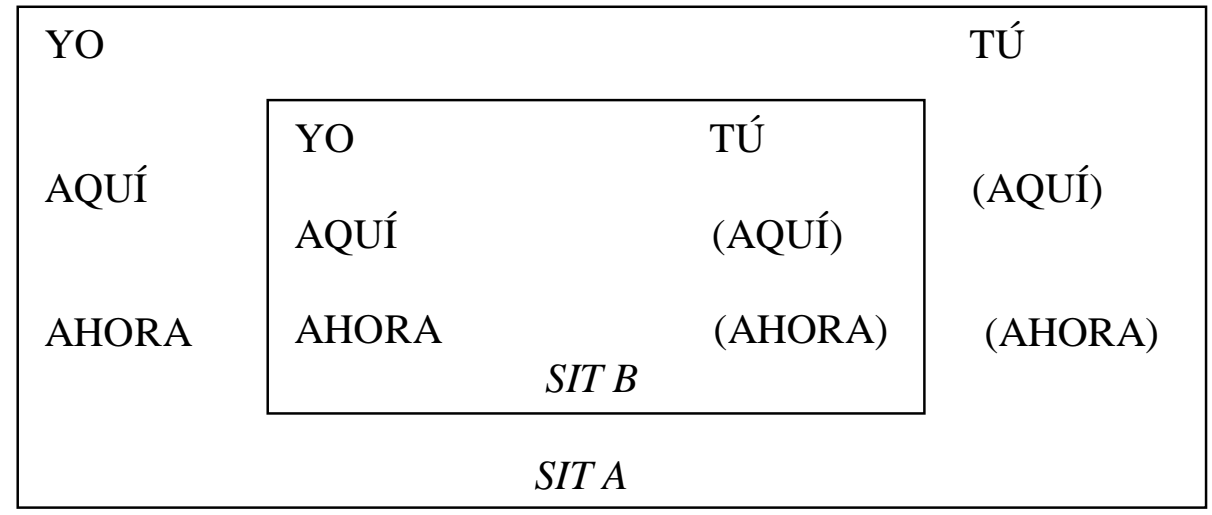

Segundo Graciela Ramos (Reyes, 1995: 35) existem três tipos de dêiticos (pessoa, espaço, tempo) que adquirem valor em cada ato de fala e que não podem se transpor intactas para um outro ato de fala. Na citação existem, pelo menos, duas pessoas, dois lugares, dois momentos que podem coincidir parcialmente. A citação, portanto, resulta em uma superposição de situações enunciativas (ver quadro superior). No que diz respeito à dêixis temporal Reyes oferece a seguinte explicação (Reyes, 1995: 38):

Expressões dêiticas:

- Verbos:

- De referência transparente: formas cujo significado se mede a partir do momento da enunciação:

\{presente, pretérito perfecto compuesto, pretérito indefinido, futuro simple y compuesto, imperativo

- De referência ambígua: formas cujo referente dêitico são formas verbais ou adverbiais do contexto, também chamados tempos relativos:

\{imperfecto, pluscuamperfecto, condicional simple y compuesto

- Advérbios e expressões temporais:

- De referência transparente: 
- Presente: hoy, ahora

- Passado: ayer, el (día de la semana, mes, año) pasado, hace poco

- Futuro: el (día, mes, año) que viene, dentro de

- De referência ambígua:

- Presente: aquel día, entonces

- Passado: el (día de la semana, mes, año) anterior, hacía poco

- Futuro: el (día, mes, año) siguiente, al cabo de

Regras de transposição

- Regra I:

Tempo de Sit A (citante) simultaneo ou posterior ao tempo de Sit B (citado) os tempos verbais não mudam no DI

Dice: "Vengo el domingo"

Dice que viene el domingo.

Dice: "Vendré el domingo"

Dice que vendrá el domingo.

- Regra II:

Tempo de Sit B (citado) anterior ao tempo de Sit A (citante) devem ser usados os tempos relativos.

Nesse caso o significado dos tempos não é transparente mas estabelecido pelo verbo principal, assim podem marcar a simultaneidade, a posterioridade ou a anterioridade em relação ao verbo principal. Igualmente, não é possível usar no DI os advérbios de tempo transparentes.

Dijo: "El tren llega por la mañana"

Dijo que el tren llegaba por la mañana.

Pensó: "Mañana haré la compra"

Pensó que al día siguiente haría la compra. 
Uma vez abordado o tema de um ponto de vista não semiótico, veja-se como é a explicação de um ponto de vista semiótico. Lembremos aqui que a debreagem é o resultado da disjunção da instância da enunciação do enunciado, é o momento da discursivização em que se constituem a categoria de pessoa, de espaço e de tempo no enunciado.

O discurso direto, DD, contem uma debreagem de segundo grau, isto é, num primeiro momento há uma debreagem de primeiro grau quando o narrador é instalado no enunciado, posteriormente quando o narrador delega a voz a uma personagem, instaurada como um interlocutor, acontece uma nova debreagem. Segundo Fiorin (2000: 177) como no discurso direto acontecem dois atos de enunciação enunciada, mesmo quando o narrador se instaura como interlocutor, dando voz a si mesmo, ocorrem dois momentos de referência distintos, sejam eles enunciativos ou enuncivos. Ao ter dois momentos de referência, os tempos de cada enunciação organizam-se em função do momento de referência ao qual remetem.

Beatriz me habló con cariño: "No sabes que alegría me da que Lubis y tú os llevéis tan bien. Porque mi hijo tiene educación aunque sea un campesino. Está más a gusto contigo que con Ubande y todos esos escandalosos",47.

O narrador projeta no enunciado o pretérito indefinido "habló" para expressar a concomitância com a anterioridade do momento de referência, é uma debreagem enunciva. Já os presentes "sabes”, “da”, “tiene”, “está”, foram instaurados no enunciado por Beatriz, a interlocutora, para expressar a concomitância com o momento de referência concomitante ao momento da enunciação, acontece assim uma debreagem enunciativa. Portanto temos dois momentos de enunciação cujos tempos organizam-se em função dos dois momentos de referência aos quais remetem.

${ }^{47}$ ATXAGA, Bernardo (2004). El hijo del acordeonista. Madrid: Alfaguara (p. 213). 
No discurso indireto, DI, acontece só uma debreagem, a instalada pelo narrador da qual depende toda a ordenação temporal.

Roberto, que se pregunta si existe una manera de defenderse de la locura, cuando la locura avanza en la oscuridad como un gato que huele a podrido y tiene linternas en los ojos ${ }^{48}$.

Toda a ordenação temporal está relacionada às projeções do narrador. Assim no exemplo, "se pregunta" indica a concomitância do momento de referência com o momento da enunciação e "existe", "avanza", "huele, "tiene" expressam a concomitância em relação ao presente de "se pregunta". Esses tempos estão subordinados à temporalização que o verbum discendi projeta no enunciado.

Quando acontece a passagem do discurso direto para o discurso indireto, o fato de acontecer a mudança de dois momentos de referência para um pode acarretar câmbios na ordenação temporal, pois com freqüência é preciso passar do sistema enunciativo para o enuncivo. As gramáticas tradicionais costumam apresentar essas mudanças na ordem temporal como se elas acontecessem sempre. Veja-se as transposições que acontecem segundo Fiorin $(2000,78)$.

1) Quando os tempos do discurso citado pertencem ao sistema enuncivo (sistema da anterioridade e da posterioridade) não haverá alteração, do discurso direto para o discurso indireto, já que o marco temporal ao qual se referem esta instalado no enunciado e se mantém.

2) Quando os tempos do discurso citado e os do discurso citante forem ambos enunciativos, não ocorrerão transformações. No entanto, apesar de não haver transformações nos tempos verbais, como os tempos do discurso indireto dependem do momento da enunciação do narrador e não do momento da fala do interlocutor, pode acontecer:

${ }^{48}$ GALEANO, Eduardo (1987). Vagamundo y otros relatos. Montevideo: Ediciones el Chanchito (p. 121). 
a) Simultaneidade do verbum discendi em relação ao ME do narrador:

1- Simultaneidade

Se dice que uno de los malhechores está herido ${ }^{49}$

2- Anterioridade

América rebusca en su mente la última vez que tuvo contacto con un hombre, se pregunta a sí misma con quién ha hablado, a quién ha mirado en el pasado reciente que calificaría como candidato para los celos de Correa $^{50}$.

\section{3- Posterioridade}

El mesero pasa con camarones cubiertos por una salsita olorosa a ajos. América se pregunta cuánto costará, y pasa el ojo por el menú $[\ldots]^{51}$

b) Anterioridade do verbum discendi em relação ao ME do narrador:

1- Simultaneidade

- No le he preguntado su opinión -contestó Miralles-. Le he preguntado si le gusta o no. A condición de que me guarde el secreto, le diré la verdad: a mí me gusta mucho ${ }^{52}$.

\section{2- Anterioridade}

Siempre me he preguntado cómo pudiste hacer esa canción sin haber estado en Lisboa $^{53}$.

3- Posterioridade

- Te he preguntado si tu madre tardará en volver. ${ }^{54}$

c) Posterioridade do verbum discendi em relação ao ME do narrador:

1- Simultaneidade

${ }^{49}$ PIGLIA, Ricardo (2000). Plata quemada. (12 a edic.). Buenos Aires: Planeta (p.172).

${ }^{50}$ SANTIAGO, Esmeralda (1996). El sueño de américa. Barcelona: Mondadori. (p.129) (CREA 28/01/2007)

${ }^{51}$ SANTIAGO, Esmeralda (1996). El sueño de américa. Barcelona: Mondadori. (p.309) (CREA 28/01/2007)

${ }^{52}$ CERCAS, Javier (2002). Soldados de Salamina. Barcelona: Tusquets (p. 182). (CREA 26/01/2007)

${ }^{53}$ MUÑOZ MOLINA, Antonio (1987). El invierno en Lisboa. Barcelona: Seix Barral (p. 158) (CREA 26/01/2007).

${ }^{54}$ MARSÉ, Juan (2000). Rabos de lagartija. Barcelona: Lumen (p. 190) (CREA 26/01/2007). 
Te dirá que es amigo mío y que me conoce desde hace años. No le creas nada, porque es un hombre sin escrúpulos ${ }^{55}$.

\section{2- Anterioridade}

Te dirá que su mujer no ha querido volver a pisar el Liceo desde aquella trágica noche y que eso le compensa la pérdida de la mano. $^{56}$

\section{3- Posterioridade}

Te dirá que [...] Que habría dado el brazo entero por no soportar más óperas ${ }^{57}$.

3) Quando o verbum dicendi estiver num dos tempos do subsistema da anterioridade e os tempos do discurso citado forem do sistema enunciativo, ocorrerão as seguintes mudanças:

a) do presente para o pretérito imperfeito:

En declaraciones a la revista Marcha, el filósofo uruguayo Washington Andrada señaló sin embargo que consideraba ese acto terrible... ${ }^{58}$

(En declaraciones a la revista Marcha, el filósofo uruguayo Washington Andrada señaló sin embargo: "considero este acto terrible...")

Bailamos muy apretados, besándonos, yo le decía que estaba enamorado de ella, ella que estaba enamorada de mí, $[\ldots]^{59}$.

Navegando con Inés escuché cómo mi abuelo le había preguntado si era hijo de fulano, nieto de mengano; $[\ldots]^{60}$.

Pensó que alguna de las personas que pasara lo vería y quizás la intuición le diría que ése no era un obrero más sino un hombre con talento ${ }^{61}$.

${ }^{55}$ LANDERO, Luis (1993). Juegos de la edad tardía. Barcelona: Tusquets (p.223) (CREA 28/01/2007).

${ }^{56}$ MENDOZA, Eduardo (1994). La verdad sobre el caso Savolta. Barcelona: Seix Barral (p. 84) (CREA 26/01/2007).

${ }^{57}$ MENDOZA, Eduardo (1994). La verdad sobre el caso Savolta. Barcelona: Seix Barral (p. 84) (CREA 28/01/2007).

${ }_{58}^{58}$ PIGLIA, Ricardo (2000). Plata quemada. (12 edic.). Buenos Aires: Planeta (p.192).

${ }^{59}$ VARGAS LLOSA, Mario (1996). La tia Julia y el escribidor. Barcelona: Seix Barral. (p. 239) (CREA 28/01/2007). 
b) do pretérito perfecto compuesto para o pretérito pluscuamperfecto:

[...] oyó sus voces y comprendió que eso era lo que le había despertado ${ }^{62}$.

(Oyó sus voces y comprendió: eso es lo que me ha despertado)

La abuela estuvo más de dos horas intentando consolarle. Le acariciaba la cabeza, le repetía tranquilízate, mi niño, le decía que no había pasado nada, que intentara dormir, el sueño lo arregla todo. ${ }^{63}$

Carmina había dicho que el abuelo había guardado los libros en el trastero $^{64}$.

La imagen del pobre emisario que Lesmes había enviado para matarme me ayudó a resolver el problema: le diría que había visto a ese hombre borracho en algún burdel ${ }^{65}$.

c) do futuro simple para o condicional simple:

Le propuso una alternativa mejor, pasaría el día en el bosque [...] y de noche dormiría en un pajar a unos doscientos metros de la casa... ${ }^{66}$

(Le propuso una alternativa mejor: "pasará el día en el bosque y durante la noche dormirá en un pajar a unos doscientos metros de la casa).

Yo le decía que algún domingo vendría a Radio Central sólo para ver al escriba transubstanciado mediante antifaces con sus criaturas. ${ }^{67}$

${ }^{60}$ BRYCE ECHENIQUE (1995). La vida exagerada de Martín Romaña. Barcelona: Alfaguara (p.22) (CREA 28/01/2007).

${ }^{61}$ QUESADA, Roberto (2000). Big Banana. Barcelona: Seix Barral (p.56) (CREA 28/01/2007).

${ }^{62}$ CERCAS, Javier (2003). Soldados de Salamina. (31 edic.). Barcelona: Tusquets (p.119)

${ }^{63}$ MARTÍNEZ DE PISÓN, Ignacio (1994). La ternura del dragón. Barcelona: Anagrama (p. 71) (CREA 28/01/2007).

${ }^{64}$ MARTÍNEZ DE PISÓN, Ignacio (1994). La ternura del dragón. Barcelona: Anagrama (p. 73) (CREA 28/01/2007).

${ }^{65}$ SALAZAR, Luis (1991). La otra selva. Bogotá: Tercer Mundo. (p.175) (CREA 28/01/2007).

${ }^{66}$ CERCAS, Javier (2003). Soldados de Salamina. (31 edic.). Barcelona: Tusquets (p.108). 
Creo que hasta me dio cierta satisfacción, porque me había preguntado si el Partido aceptaría mi relación con frau Trude ${ }^{68}$.

-Lo primero que haría en tal caso -añadió-, sería apelar al inajenable derecho histórico de cada país para gobernarse a sí mismo. Le respondería con la soberanía nacional, que es algo muy manido pero muy aceptado y difundido en el derecho internacional. Y, desde luego, le diría que esa unión exigiría una consulta a nivel casi popular. Digamos, un referéndum ${ }^{69}$.

4) Quando o verbum dicendi estiver num dos tempos do subsistema da posterioridade, não ocorrerão mudanças:

a) Presente:

Ella preguntará quién es el que ha tomado esa decisión. Él contestará que esas decisiones no se toman $^{70}$.

b) Pretérito perfecto compuesto:

Le sacará toda la pasta que pueda y luego dirá que le han pagado muy $\operatorname{poco}^{71}$.

c) futuro simple:

Quando os advérbios não concordarem com a situação de enunciação deverão alterar-se, passando do sistema enunciativo para o enuncivo ou vice-versa.

Para concluir, o fato de abordar a passagem do DD para o DI segundo a teoria de Fiorin, abrange e amplia a explicação de Graciela Reyes, permitindo explorar os diferentes valores que os tempos verbais ganham dependendo de atuarem no sistema enuncivo ou no

${ }^{67}$ VARGAS LLOSA, Mario (1996). La tia Julia y el escribidor. Barcelona: Seix Barral (p. 165) (CREA 28/01/2007).

${ }^{68}$ ALBA, Vítor (1975). El pájaro africano. Barcelona: Planeta (p. 215) (CREA 28/01/2007).

${ }^{69}$ VAL, José Maria del (1983) Llegará tarde a Hendaya. Barcelona: Planeta (p.141) (CREA 28/01/2007).

${ }^{70}$ CHACÓN, Dulce (2002). La voz dormida. Madrid: Alfaguara (p.264) (CREA 28/01/2007).

${ }^{71}$ TOMÁS GARCÍA, José Luis (1985). La otra orilla de la droga. Barcelona: Destino (p. 76) (CREA 28/01/2007). 
sistema enunciativo. Isto é, levando em consideração a relação entre o momento do acontecimento, o momento da referência e o da enunciação, seja com as formas verbais, seja com os advérbios, se torna possível explicar com maior precisão as mudanças que acontecem no discurso, entendido como sistema de signos em uma estrutura.

\section{Subjuntivo}

O estudo do subjuntivo é um dos trabalhos mais árduos para qualquer um que se aproxime da língua espanhola. Sistematizar seus usos resulta, na maioria dos casos, em listados difíceis de aprender, tanto se for o caso de um estudante de espanhol como de um aprendiz de língua estrangeira. Embora não seja o objetivo de este capítulo o estudo exaustivo do seu uso, serão abordados alguns dos enfoques que os estudiosos dão, os conectores com os quais aparece e, finalmente, a relação de correlação temporal que se estabelece entre o tempo da oração principal e o tempo da oração subordinada. 
O tempo da oração principal serve para a oração subordinada que usa subjuntivo como o momento de referência, nesse marco referencial serão estudadas as relações que se estabelecem desde o ponto de vista da enunciação segundo a teoria de Fiorin que foi adotada ao longo deste trabalho.

A abordagem das gramáticas ou dos estudos específicos sobre a categoria modal parte da oposição indicativo/ subjuntivo, reservando para o indicativo a esfera da realidade e para o subjuntivo a do irreal (Esbozo, 1986: 476), caracterizando o indicativo como o modo da precisão, dos fatos e da imposição objetiva dos fenômenos, enquanto o subjuntivo é considerado o modo da ambigüidade, da imprecisão, da virtualidade, do hipotético, da avaliação subjetiva (Sastre, 1997: 15). Lidia Lozano $(2005)^{72}$, uma vez analisados e sistematizados os usos do subjuntivo, aponta a oposição realização / não realização atribuindo a primeira para o uso do indicativo e a segunda para o uso do subjuntivo.

Alarcos estuda o modo subjuntivo levando em consideração dois critérios. O primeiro critério, o da compatibilidade com as modalidades de enunciado (Alarcos, 2002: 191), reúne as formas possíveis de se apresentarem com entoação interrogativa como cantas, cantabas, cantaste, cantarás, cantarías em um grupo. E em outro grupo, as formas que com as quais não é possível se expressar com entoação interrogativa como cantes, cantases, cantaras, cantares. Estamos diante das formas de indicativo, o primeiro conjunto, e das formas do subjuntivo, o segundo conjunto. Alarcos explica também que há sido usado o termo potencial o condicional para denominar o modo particular da forma cantarías, mas quando as possibilidades combinatórias coincidem com as do futuro de indicativo, cantarás, o autor sugere ou deixar as duas no modo indicativo ou colocá-las como um modo especial intermediário entre indicativo e subjuntivo (Alarcos, 2002: 191).

Um segundo critério é aquele que considera as dependências sintáticas em orações transpuestas, Alarcos (Alarcos, 2002: 191) coincide com Bello em mostrar que o indicativo aparece em frases como: creo que viene, creo que venía, creo que vino, creo que vendrá,

\footnotetext{
${ }^{72}$ LOZANO, Lidia (2005). "Hacia una única explicación del subjuntivo aplicado a la adquisición de E/LE" em: Cuadernos Cervantes de la Lengua Española. Año nº 11, número: 56.
} 
creo que vendría, enquanto não é possível esta construção, e, pelo contrário, é necessário o subjuntivo, em frases como no creo que venga, no creo que viniera o viniese.

Continua o autor explicando que existem casos em que nenhum desses critérios serve para determinar o morfema de modo que deve ser usado nas formas verbais pois essa escolha depende exclusivamente do falante, quem tem como objetivo comunicar uns valores e não outros. Examinando os exemplos que seguem:

1) Aunque tiene dinero, sigue el mismo

Aunque tenía dinero, seguía el mismo

Aunque tuvo dinero, siguió el mismo

2) Aunque tendrá dinero, seguirá el mismo

3) Aunque tenga dinero, sigue (seguirá) el mismo

Aunque tuviera/ tuviese dinero, seguirá el mismo

Alem das diferenças que são introduzidas pelos morfemas de tempo, nos exemplos acima, situando a ação em diferentes momentos temporais, observa-se que no caso do uso do indicativo, exemplos do item 1), a posse de dinheiro é efetiva, é real. Já no uso do subjuntivo, exemplos do item 3), a posse de dinheiro não é real, apresenta-se como um fato fictício. No caso do uso do futuro, em outros contextos poderia ser um condicional, expressa uma possibilidade, exemplo do item 2), não tem dinheiro mas pode ser o caso de ter. $\mathrm{O}$ uso de qualquer um dos enfoques apresentados depende exclusivamente de como o falante quer colocar os fatos, isto é, do grau de realidade que atribui aos fatos denotados (Alarcos, 2002: 192).

Alarcos conclui que o significado de modo resulta gramaticalmente em três modos:

1- Os fatos considerados reais, ou cuja realidade não é do interesse do falante são expressos no modo indicativo.

2- $\quad$ Os fatos cuja realidade é possível, sempre que se cumpram algumas condições, são expressos no modo condicional. 
3- Os fatos fictícios, por não ser conhecida a realidade o por ser evidente a não realidade, são expressos no modo subjuntivo.

Para finalizar com a teoria de Alarcos, o autor acrescenta como essa divisão das categorias modais corresponde-se com o comportamento a respeito das modalidades do enunciado. Assim, a modalidade interrogativa unicamente é possível aplicá-la aos fatos estimados como reais. Quando se inquire ¿quién canta?, o morfema de indicativo da forma verbal denota um fato real, já que não faz sentido perguntar pelo ator de uma ação no caso de ¿quién cante?, pois o morfema de subjuntivo já está dizendo que é uma ação fictícia. Em outros casos é o critério de dependência sintática que se impõe, pois não existe a possibilidade de escolher entre os modos, é o caso do verbo creer, por exemplo. O verbo creer refere-se a um fato real, não fictício, portanto, ira seguido de indicativo na oração subordinada. Já, pelo contrário, verbos que semanticamente denotam noções de incerteza ou de fatos fictícios serão seguidos de subjuntivo como, por exemplo, dudo de que venga, espero que venga (Alarcos, 2002: 194).

Ruiz Campillo, em um artigo intitulado El subjuntivo es lógico: una actividad de concienciación, (Ruiz Campillo, 2001: 33) agrupa as manifestações do subjuntivo em matrices intencionales (quiero que, te pido que...) matrices veritativas (creo X, pienso X, me parece $\mathrm{X}$, supongo $\mathrm{X}$...) e matrices de comentario (me gusta $\mathrm{X}$, es bonito $\mathrm{X}$, lamento $\mathrm{X...)}$ atribuindo ao indicativo um valor declarativo e ao subjuntivo o valor no-declarativo. Define-se declaración como "aquilo que é pensado sobre o mundo", assim, por exemplo, quando enunciamos te pido $\mathrm{X}$, o pedido é um objeto não declarável pois não é efetivo, em caso de sê-lo não precisaria pedir. A mesma explicação poderia ser aplicada para os casos das restantes matrizes em que $\mathrm{X}$ é a declaração, exemplo:

Creo X ........... Creo que tiene fiebre (indicativo)

No creo X ......... No creo que tenga fiebre (subjuntivo)

Não é aceitável No creo que "tiene" fiebre (indicativo). Ao negar X, $\mathrm{X}$ não é a declaração, se colocarmos $\mathrm{X}$ em indicativo incorre-se em 
uma contradição, pois não é possível não acreditar em algo expresso como certo.

Nas matrizes de comentário, o objeto do comentário será representado em subjuntivo, ou seja, de forma não-declarativa. Veja-se o seguinte exemplo:

Es estupendo X ........... Subjuntivo (X não é o comentário e sim o objeto do comentário. O comentário, propriamente dito é que eso (X) es estupendo).

Ruiz Campillo conclui que é preciso ter uma clara consciência do significado das matrizes para diferenciar tanto produtiva como interpretativamente o uso do modo (Ruiz Campillo, 2001: 34).

As teorias sobre o uso do subjuntivo não são, de modo algum, nem definitivas nem excludentes, muito pelo contrário complementam-se as umas com as outras no intuito de explicar o funcionamento do modo. Se formos considerar o critério sintático, segundo o qual algumas clausulas subordinadas funcionam em determinadas ocasiões com subjuntivo e em outras com indicativo, apresenta-se seguidamente um esquema ${ }^{73}$ das orações subordinadas e seus nexos que no espanhol expressam-se com subjuntivo.

1. Com verbos denominados de pensamento ou entendimento (creer, saber, considerar, decir, ser, necesitar...) emprega-se:

- INDICATIVO: Para expressar certeza, verdade objetiva, constatação dos fatos.

Creo que dice la verdad

Es indudable que viene

Sé lo que pasa 
Consideró que la sentencia era justa

- SUBJUNTIVO: Para expresar incerteza, hipótesis, fatos no constatados.
No creo que venga
Dudo que te llame
Me extraña que lo sepa
Quiere que vaya

2. Nas orações que funcionam como sujeito dos verbos ser e estar emprega-se:

- INDICATIVO quando o verbo principal expressa a constatação de um fato:
Es evidente que lo han descubierto
Está claro que no sabe nada
Es cierto que está embarazada

Igualmente é utilizado o indicativo com:

es seguro que... está visto que...., está claro que..., está demostrado..., etc.

- SUBJUNTIVO quando o verbo da oração principal expressa dúvida o valoração :

Es importante que estés preparado

Es aconsejable que no digáis nada

Es una vergüenza que escribas tan mal

Constroem-se igualmente com subjuntivo:

es posible que..., es probable que..., es lógico que...., es mejor que..., es natural que..., etc.

\footnotetext{
${ }^{73} \mathrm{O}$ esquema apresentado baseia-se na classificação, assim como nas definições e exemplos, de $\mathrm{M}^{\mathrm{a}}$ Ángeles
} 
3. As orações concessivas exprimem uma objeção ou dificuldade para o cumprimento da ação indicada pelo verbo principal, sem que esse obstáculo empeça o cumprimento da ação principal.

Os nexos usados com maior freqüência são:

aunque

Aunque sea rico, no nos ayudará

por mucho/poco/más que ...

Por mucho que trabaje, nunca consigo ahorrar

por más/mucho,a,os, as + sustantivo + que

Por mucho dinero que tenga, no nos ayudará

por muy + adjetivo o advérbio + que

Por muy rico que sea, no nos va a prestar dinero

Pelo geral, com aunque, utilizaremos:

- INDICATIVO quando a oração subordinada constata um fato:

Aunque es muy guapo, a mí no me gusta

- SUBJUNTIVO quando a oração subordinada expressa um fato não experimentado ou verificado:

Aunque sea muy guapo, no me va a gustar

4. Nas orações temporais utiliza-se:

Sastre no seu livro El subjuntivo en español (vid. bibliografia) 
- INDICATIVO quando a ação exprimida pelo verbo subordinado expressa um fato habitual (cuando=siempre que).

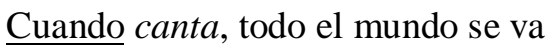

Cuando llega, se sienta siempre a mi lado

- SUBJUNTIVO quando o verbo subordinado apresenta uma ação não realizada ou por verificar.

Cuando venga saldremos de paseo

Cuando acabe la película me voy a acostar.

5. Nas orações condicionais introduzidas por si:

Estas orações podem admitir indicativo ou subjuntivo conforme a natureza da condição expressa.

\section{Condição realizada}

- Ação habitual no pasado: Pret. Imperfecto de indicativo

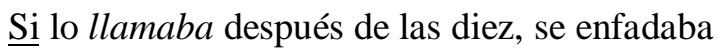

- Ação pontual: Pret. Indefinido

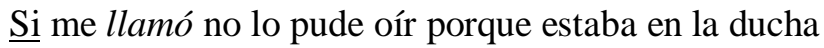

- Condição realizável: Presente de indicativo

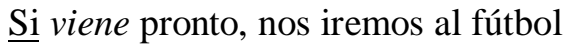

Si llama, dile que no estoy

- Condição irrealizável ou de difícil realização: Pret. Imperfecto de subjuntivo

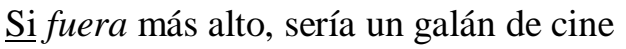

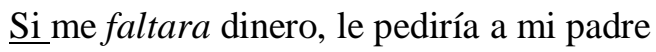




\section{- Hipótese no pasado: Pret. Pluscuamperfecto de subjuntivo}

Si lo hubiera sabido, habría ido contigo (hubiera ido)

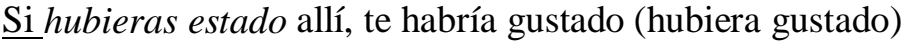

6. Nas orações adjetivas de relativo especificativas usa-se:

- INDICATIVO: quando a oração subordinada faz referência a um antecedente conhecido, isto é, pessoas, coisas, fatos ou situações, assim como a verdades gerais.

El trabajador que habló de huelga fue despedido

La Tierra es el planeta en el que se ha desarrollado vida humana

- SUBJUNTIVO: quando o falante faz referência a um antecedente não especifico ou conhecido, isto é, pessoas, coisas, fatos ou situações, ou que não esta interessado em dar a conhecer. Assim como quando existe negação implícita ou explícita do antecedente.

Busco secretaria que sepa inglés, francés y alemán

Ganará un punto quien responda a mi pregunta

Nunca he visto una película que acabe tan mal

No paradigma verbal, as formas para o subjuntivo são consideravelmente um número menor e não expressam com tanta nitidez e precisão seus limites. As formas do subjuntivo dependem do verbo principal e estabelecem com ele uma relação de anterioridade, concomitância e posterioridade, sem esquecer que mantêm essas relações dentro de cada subsistema, seja o enunciativo, seja o enuncivo. Seguidamente serão apresentadas as formas do paradigma do subjuntivo e posteriormente as relações de concomitância $v s$. não concomitância (anterioridade $v s$. posterioridade) em função do verbo principal. 
Presente

Cante

Pretérito imperfecto

Cantaral cantase
Pretérito perfecto compuesto

Haya cantado

Pretérito pluscuamperfecto

Hubiera / hubiese cantado

\section{- Sistema enunciativo}

Se o tempo da oração principal for um dos tempos do subsistema enunciativo (presente, pretérito perfecto compuesto, futuro simple) ocorrerão as seguintes possibilidades:

\section{Concomitância}

a) Anterioridade: pretérito perfecto compuesto (haya cantado)

Mi otro amigo prefirió a una gordísima odalisca, con quien dudo que haya podido realizar ninguna proeza, debido a su edad avanzada y su frágil esqueleto, pero, en todo caso, salió con ella, también tragados por la cortina $^{74}$.

b) Concomitancia: presente (cante)

Temo que quiera llevar a cabo represalias, aunque dudo que se atrevan a dirigirlas contra usted ${ }^{75}$.

c) Posterioridade: presente (cante)

\footnotetext{
${ }^{74}$ ALLENDE, Isabel (1995). La casa de los espíritus. Barcelona: Plaza y Janés (p.58) (CREA 25/01/2007).

${ }^{75}$ MENDOZA, Eduardo (1994). La verdad sobre el caso Savolta. Barcelona: Seix Barral (p.118) (CREA 25/01/2007).
} 
- Y yo te quiero a ti; seremos esposos; pero esta noche no quiero estar contigo; quizá sea que ya sé que la decisión está hecha; tal vez siento que esta noche será la última que pasaré como una mujer soltera; ya me he comprometido totalmente a ti; no importa lo que pase de aquí en adelante; yo seré tu mujer;... ${ }^{76}$

\section{Anterioridade}

a) Anterioridade: pretérito perfecto compuesto (haya cantado)

“ [...] Parece, no obstante, comprobado que nunca ha sobrevivido ninguna camada que haya consumido ese tipo de carne, considerada mortalmente venenosa." ${ }^{17}$

b)Concomitância: pretérito imperfecto (cantara/cantase)

Estaba conmigo, no porque me apreciase sino porque se sentía solo.

c) Posterioridade: pretérito imperfecto (cantara/cantase)

Insisití para que entrase pero no quiso.

\section{Posterioridade}

a) Anterioridade: pretérito perfecto compuesto (haya cantado)

Dejo mis borrones como ciertos animales dejan su cáscara. Dejar la cáscara no es lo mismo que dejar el cascarón. Dejar el cascarón es dejar el esqueleto. Aquí está mi esqueleto, pues, entre la mesa y la silla. Será eso lo que encuentren una vez que haya dormido y los ruidos se metan por el arco de la ventana ${ }^{78}$.

b) Concomitância: presente (cante)

\footnotetext{
${ }^{76}$ MORALES, Alejandro (1979) La verdad sin voz. México D.F.: Joaquín Mortiz (p.71) (CREA 25/01/2007).

${ }^{77}$ MARTÍNEZ DE PISÓN, Ignacio (1994). La ternura del dragón. Barcelona: Anagrama (p. 133) (CREA 25/01/2007).

${ }^{78}$ GONZÁLEZ LEÓN, Adriano (1995). Viejo. Madrid: Alfaguara (p.92) (CREA 25/01/2007).
} 
- Agradece a Vuestra Majestad su intercesión. Dice que no tendrá reposo de conciencia hasta que vea suspendida la sentencia de muerte al soldado. ${ }^{79}$

c) Posterioridade: presente (cante)

- Antonio me agradece y me agradecerá lo ocurrido hasta que se vuelva viejo y tenga nietos. Eso es lo que andábamos buscando, que pudiera llegarme como ella, con la misma gratuita suavidad ${ }^{80}$.

- Les sorprenderá que a esta película no le hayan dado ningún premio. ${ }^{81}$

\section{- Sistema enuncivo: anterioridade}

Se o tempo da oração principal for um dos tempos do subsistema enuncivo da anterioridade (pretérito imperfecto, pretérito perfecto simple, pretérito pluscuamperfecto, pretérito anterior, condicinal simple, condicional compuesto) ocorrerão as seguintes possibilidades:

\section{Anterioridade}

pretérito pluscuamperfecto (hubiera/ hubiese cantado)

Por lo que me habían contado de él, hubiera reconocido a James aunque hubiera entrado solo ${ }^{82}$.

\section{Concomitancia}

pretérito imperfecto (cantara/cantase)

Le hizo un gesto a Leonor para que viniera al balcón, gritando unas palabras que ella no pudo oír, separados como estaban por el mar de ruido que estremecía la recámara ${ }^{83}$.

\footnotetext{
${ }^{79}$ VALLEJO-NÁGERA, Juan Antonio (1994) Yo, el rey. Barcelona: Planeta (p. 167) (CREA 26/01/2007).

${ }^{80}$ ROSSI, Ana Cristina (1985) María la noche. Barcelona: Lumen. (p.165) (CREA 26/01/2007).

${ }^{81}$ Exemplo apresentado por M ${ }^{\mathrm{a}}$ Ángeles Sastre (Sastre, 1997: 34)
} 


\section{Posterioridade}

pretérito imperfecto (cantara/cantase)

- Me contaron que esa tarde habían firmado contrato con Lucho Gatica para que viniera una semana a Lima como exclusividad de Panamericana.. ${ }^{84}$

- Pero aquello estaba lejano aún, y además habría sido mejor que no llegara nunca, sí, habría sido mejor seguir dudando toda la vida, porque aquella vez me tocó vivir una de las situaciones más exageradas del mundo ${ }^{85}$.

\section{- Sistema enuncivo: posterioridade}

Se o tempo da oração principal for um dos tempos do subsistema enuncivo (futuro simple, futuro compuesto) ocorrerão as seguintes possibilidades:

\section{Anterioridade}

Usted, una vez que haya terminado la traducción, podrá cortarse esa melena y afeitarse, y trabajar en Llaguapí de animador multilingüe para visitantes extranjeros. $^{86}$

\section{Concomitancia}

"Feliz contigo afrontaré el destino - tu mano siempre guardará mi mano - y cuando llegue al fin de mi camino - moriré como muere un mexicano. ${ }^{17}$

\footnotetext{
${ }^{82}$ PUERTOLA, Soledad (1993) Queda la noche. Barcelona: Planeta (p. 64) (CREA 26/01/2007).

${ }^{83}$ AGUILAR CARMIN, Hector. (1995) El error de la luna. México D.F.: Alfaguara. (p.28) (CREA 26/01/2007).

${ }^{84}$ VARGAS LLOSA, Mario (1996). La tia Julia y el escribidor. Barcelona: Seix Barrarl (p. 68) (CREA 26/01/2007).

${ }^{85}$ BRYCE ECHENIQUE (1995). La vida exagerada de Martín Romaña. Barcelona: Alfaguara (p.135) (CREA 26/01/2007).

${ }^{86}$ LABARCA, Eduardo (1994). Butamalón. Madrid: Anaya y Mario Muchnik (p. 252) (CREA 27/01/2007).

${ }^{87}$ POMBO, Álvaro (2004). Una ventana al norte. Barcelona: Anagrama (p.134) (CREA 26/01/2007).
} 


\section{Posterioridade}

- Eso te aliviará, Carlos -le dije, siguiéndolo para sostenerle la cabeza.

- Sin duda -me había dicho, entre un pasmo y otro-, pero no ahora sino cuando haya terminado, o sea pasado mañana, con suerte. ${ }^{88}$

Para concluir serão apresentadas as relações temporais mais freqüentes entre o indicativo / subjuntivo segundo o modelo recolhido no Esbozo (Esbozo, 1986: 477)

\begin{tabular}{|c|c|c|c|}
\hline & INDICATIVO & \multicolumn{2}{|c|}{ SUBJUNTIVO } \\
\hline \multicolumn{2}{|c|}{ Creo que Juan llega hoy } & \multirow{2}{*}{\multicolumn{2}{|c|}{ No creo que Juan llegue hoy }} \\
\hline \multicolumn{2}{|c|}{ Creo que Juan llegará hoy } & & \\
\hline \multicolumn{2}{|c|}{ Creo que Juan ha llegado hoy } & \multirow{2}{*}{\multicolumn{2}{|c|}{ No creo que Juan haya llegado hoy }} \\
\hline \multicolumn{2}{|c|}{ Creo que Juan habrá llegado hoy } & & \\
\hline \multicolumn{2}{|c|}{ Creí que Juan venía } & No creí que & \multirow{3}{*}{ Juan viniera/viniese } \\
\hline \multicolumn{2}{|c|}{ Creí que Juan vendría } & No creía que & \\
\hline \multicolumn{2}{|c|}{ Creo que Juan vino } & No creo que & \\
\hline \multirow{2}{*}{ Creía que } & Juan había venido & \multirow{2}{*}{\multicolumn{2}{|c|}{ No creía que Juan hubiera/hubiese llegado }} \\
\hline & Juan habría venido & & \\
\hline
\end{tabular}

Foi verificado neste capítulo que a correlação dos tempos verbais, entre os tempos do indicativo e os tempos do subjuntivo, responde ao mesmo critério que foi utilizado para explicar os tempos do indicativo. Os tempos do subjuntivo estão relacionados com o momento da enunciação por meio do momento de referência do tempo de indicativo que aparece na oração principal. É assim como o eixo criado pelo agora do ato da enunciação, concomitância, não-concomitância alcança todas as manifestações temporais.

\footnotetext{
${ }^{88}$ BRYCE ECHENIQUE (1995). La vida exagerada de Martín Romaña. Barcelona: Alfaguara (p.338) (CREA 27/01/2007).
} 


\section{Embreagem temporal}

Todos os autores consultados ao longo deste trabalho coincidem em afirmar que existe a possibilidade de um tempo verbal, em determinados contextos, deixar de lado o seu valor principal para assumir o valor de outro tempo para, assim, criar um efeito de sentido.

Bello (1984: 211) explica que do significado próprio e fundamental das formas indicativas derivam os significados secundários, por meio de determinadas transformações sujeitas a uma lei constante. Rojo e Veiga (Rojo e Veiga, 1999: 2849) apontam que todas as formas verbais possuem um valor recto que responde a um valor próprio de cada forma e 
valores dislocados ou desplazados que aparecem sistematicamente como conseqüência da expressão de um valor temporal distinto do valor recto.

Retomando a teoria de Fiorin (Fiorin, 2001: 191) ao contrário da debreagem temporal, definida como a projeção para fora da instancia da enunciação, seja em um enunciado que represente o simulacro da enunciação, enunciação enunciada, seja em um enunciado que não represente uma enunciação, enunciado enunciado, a embreagem é “o retorno à instância da enunciação produzido pela suspensão da oposição entre certos termos $" 89$.

A debreagem resulta em uma enunciação enunciada quando os tempos do enunciado simulam os tempos da enunciação, esse processo produz a impressão de estar em presença do ato de dizer. Quando a debreagem resulta em um enunciado enunciado, iludimo-nos diante da temporalidade do acontecimento. Em quaisquer dos casos prevalece a impressão de estar diante de um tempo não lingüístico, pois sentimo-nos imersos no ato de dizer ou nos próprios acontecimentos, no dito. Pelo contrário quando um termo da categoria do tempo é neutralizado por outro, ou seja quando não existe mais a oposição entre esses dois termos, o efeito de sentido que se produz é o de que o tempo é pura construção do enunciador, que presentifica o passado, torna o futuro presente, etc. nesse momento fica claro que o tempo é um efeito de sentido produzido pela enunciação (Fiorin, 2001: 191).

Os tempos verbais podem-se neutralizar:

- Um tempo enunciativo e um tempo enuncivo correspondentes

- Um termo da categoria topológica e outro, dentro do mesmo sistema ou subsistema temporal

- Um termo da categoria topológica com outro de um sistema ou subsistema temporal distinto.

\footnotetext{
${ }^{89}$ Fiorin esta citando nesse ponto a Greimas e Courtès.
} 
O resultado da neutralização manifesta-se pela suspensão de um dos tempos, ou seja, um tempo é utilizado com o valor do outro. Existem dois tipos de embreagens:

- Embreagem enunciativa: ocorre quando o resultado da enunciação é um tempo enunciativo, ou seja, dois tempos do sistema enunciativo neutralizam-se entre eles ou um tempo do sistema enuncivo é neutralizado por outro do sistema enunciativo. O resultado é sempre um tempo do sistema enunciativo.

- Embreagem enunciva: ocorre quando o resultado da enunciação é um tempo enuncivo, ou seja, dois tempos do sistema enuncivo neutralizam-se entre eles ou um tempo do sistema enunciativo é neutralizado por outro do sistema enuncivo. O resultado é sempre um tempo do sistema enuncivo.

Pode-se aplicar, igualmente, para os advérbios exceto para aqueles que expressam precisão crônica, por exemplo uma data. Os advérbios só podem se neutralizar quando manifestam tempo lingüístico.

Destaque-se a diferença entre neutralização e erro no emprego das marcas de temporalidade. No primeiro caso, a transgressão esta justificada, cria um efeito de sentido que pode ser considerada ate efeito de estilo do enunciador. Já no segundo caso, a transgressão não gera efeito de sentido algum.

1. Entonces dijiste que cogerías el próximo vuelo, que no esperarías más, y todavía estás aquí.

2. Cristóbal Colón llega a tierras americanas en 1492.

No primeiro exemplo, não existe efeito de sentido. $\mathrm{O}$ enunciador estava utilizando um sistema enuncivo, marcado temporalmente por entonces, deveria ter usado siguiente para se referir ao vôo em que embarcaria naquele momento. Pelo contrário, no segundo exemplo, o marco temporal que vem expresso com uma data precisa do uso de um pretérito perfecto simple, no entanto o uso do presente aproxima os acontecimentos. É um recurso estilístico. Percebe-se o efeito de sentido porque no enunciado, no discurso, aparece uma 
marca da debreagem temporal, a data, que faz com que se saiba que o presente está sendo usado no lugar de outro tempo. Como para ocorrer uma embreagem é preciso que com anterioridade tenha acontecido uma debreagem, essa debreagem tem que deixar uma marca discursiva pela qual se perceba que foi realizada uma neutralização.

No plano teórico, qualquer tempo poderia ser empregado com o valor do outro, considerando que se podem neutralizar um tempo do sistema enunciativo com os tempos correspondentes de cada um dos subsistemas enuncivos, tempos da categoria topológica e outro dentro do mesmo sistema ou subsistema e tempos da categoria topológica com outros de um sistema ou subsistema temporal distinto. Em teoria todas as possibilidades combinatórias são possíveis, na prática nem todas são admitidas pelo espanhol ${ }^{90}$. A continuação serão apresentadas as neutralizações que foram verificadas que acontecem no sistema verbal do espanhol. Não se descarta a possibilidade da existência de neutralizações que não foi possível verificar no presente trabalho pela dificuldade para serem exemplificadas. Os exemplos foram retirados em alguns casos do Corpus referência del español actual, que a Real Academia Española tem a disposição de qualquer usuário no seu site, outros da amostra apresentada nas gramáticas e manuais consultados, outros são exemplos que autora criou para tais fins, gramaticalmente corretos, utilizados num espanhol padrão.

\section{A) Neutralização dentro de um mesmo sistema.}

1. concomitância 1 pela anterioridade 1 (presente pelo pretérito perfecto compuesto). Neutralização de um termo da categoria topológica por outro do mesmo sistema. É o chamado presente perfectivo, não significa que o presente seja equivalente a um passado mas que em determinadas condições a oposição fica anulada.

Ocorre esta neutralização na negação de um presente de um verbo perfectivo. Nesse caso, expressa-se impaciência porque o fato que esperamos não acontece.

\footnotetext{
${ }^{90}$ Ver as possibilidades teóricas recolhidas por Fiorin (Fiorin, 1986: 194-196)
} 
¡No llama!.

Estamos expressando que no momento em que é enunciada a ação ainda não aconteceu, no ha llamado, e que esperamos que aconteça.

Alguns verbos perfectivos admitem esta neutralização quando se considera como resultado do significado verbo perfectivo o efeito continuado de ele.

Traigo vino para nosotros y chocolate para ti.

Quando não foi entregue o objeto trazido, he traído, o efeito permanece.

Acontece a mesma equivalência com verbos que designam atos psíquicos, sejam momentâneos ou duradouros.

No me trates así. ¿quién te piensas que eres?

O presente aparece no lugar do perfecto, ¿quién te has pensado que eres? Ambas expressões são manifestação de censura, reeprensão.

Com verbos de percepção, dependendo da natureza da ação ou do fenômeno que é o conteúdo da percepção.

Ya veo que no has cambiado nada.

O presente substitui ao perfecto onde debería dizer he visto.

Interpretado como uma repreensão ou como comentários exclamativos em que o enunciador expressa insatisfação ou descontento.

Yo todo el día limpiando la casa y en un momento lo ensucias todo 
O verbo ostenta nuances de reprovação, ensucias, não se refere ao fato de ter acontecido nesse instante presente.

O presente de ação imediata é empregado quando se comunica uma noticia a alguém que não está presenciando o fato. Pode ser, por exemplo, a retransmissão de um jogo de futebol ou a manchete de um jornal ou o pé de foto.

2. concomitância 1 pela posterioridade 1 (presente pelo futuro simple). Neutralização de um termo da categoria topológica e outro do mesmo sistema. São os presentes prospectivos e voluntativos que se referem a acontecimentos que podem ser imediatos ou não e que podem aparecer com caráter volitivo. Examinaremos alguns exemplos.

No te preocupes, me quedo contigo.

De acuerdo, yo llevo la bebida.

Em ambos exemplos o uso do presente expressa uma ação futura imediata, no segundo tem um valor adicional de determinação, de decisão.

Em outras ocasiões não tem esse valor de um acontecimento iminente no entanto aparece como um fato planejado.

Nosotros nos volvemos a España.

Pode aparecer em situações em que se representam acontecimentos não desejados, assim como em formulações ameaçadoras.

En unos minutos está aquí y nos pone a trabajar.

Un día de estos lo dejo todo y me voy. 
O presente prospectivo acompanha expressões como: a lo mejor, si, a ver como/ cuando/ si.

A ver como te portas.

A ver cuando vienes a visitarme de nuevo.

Estes presentes quando negados adquirem o tom de uma afirmação categórica.

Yo no me voy sin que me paguen lo que me deben.

O presente voluntativo não coincide exatamente com o prospectivo embora em ocasiões expresse nuances de desejo, ameaça, temor, rejeição, ordem. A maioria dos usos do presente voluntativo possuem valor imperativo.

Juro que te arrepientes.

3. anterioridade 1 pela concomitância 1 (pretérito perfecto compuesto pelo presente) Neutralização de um termo da categoria topológica por outro do mesmo sistema.

Na narração, usa-se o pretérito perfecto compuesto com um significado de presente fictício quando a ação mencionada é geralmente posterior mas não está situada num momento temporal. Frequentemente é acompanhado por presentes.

En la soledad de la noche, cuando todos duermen, cuando nada turba el silencio, observa lo que está haciendo. Ha cogido un amplio pañuelo, lo ha extendido en la mesa y en él va poniendo [...] (Azorín, $O C$, vi, 105) $)^{91}$

\footnotetext{
${ }^{91}$ Exemplo tomado de Fernández Ramírez, (1986, p.246).
} 
4. posterioridade 1 pela concomitancia 1 (futuro simple pelo presente) neutralização de um termo da categoria topológica e outro dentro mesmo subsistema.

Em frases exclamativas, com a idéia de surpresa, pode substituir o presente:

Pero, i¿será posible?! O sea, que a mí, que estoy trabajando, no importa que se me interrumpa todo el rato. Pero al señorito Diego, como ha dicho que no se le moleste, usted no se atreve ni a decirle que le llaman por teléfono. ¡Cielos! ${ }^{92}$

5. anterioridade 1 pela posterioridade 1 (pretérito perfecto compuesto pelo futuro simple).

Va a conseguir la plaza, mejor dicho, ya la ha conseguido.

O pretérito compuesto dá por feito um fato que ainda está por acontecer mas que esta em vias de realização no presente.

6. concomitância pontual 2 pela concomitância durativa 2 (pretérito perfecto simple pelo pretérito imperfecto)

Que las mujeres no trabajasen fue normal en la época de nuestras madres.

O uso do perfecto acaba com o caráter habitual do fato que as mulheres não trabalhassem na época da ação e da um sentido perfectivo.

7. concomitância durativa 2 pela concomitância pontual 2 (pretérito imperfecto pelo pretérito perfecto simple).

${ }^{92}$ RICO GODOY, Carmen (1995). Cómo ser una mujer y no morir en el intento. Madrid: Ediciones Temas de Hoy (p.102) (CREA 19/02/07). 
Estamos diante do imperfecto puntual (Fernández Ramírez, 1986, p. 281) empregado em casos em que os hábitos lingüísticos fariam esperar um pretérito perfecto simple) por anunciar um ato concluso e singular.

Alberto recordó que la víspera, a la misma hora aproximadamente, cruzaba los jardines del brazo con Rosina ((Pérez de Ayala, la pata de la raposa, 31$)^{93}$.

8. concomitancia pontual 2 pela anterioridade 2 (pretérito perfecto simple pelo pretérito pluscuamperfecto).

9. concomitância durativa 2 pela anterioridade 2 (pretérito imperfecto pelo pretérito pluscuamperfecto).

Estaba esperando en la consulta, acababa de llegar hacía cinco minutos.

O marco de referencia temporal é a anterioridade, expresso pela concomitância durativa do imperfecto, acababa de llegar faz referência a um momento anterior à concomitância mas usando o imperfecto tem-se a impressão de que ressoa no presente do narrado.

10. concomitância pontual 2 pela posterioridade 2 (pretérito perfecto simple pelo condicional)

Quería saber lo que pasaba en la sala de operaciones pero solo tuvo noticias cinco horas después.

${ }^{93}$ Exemplo tomado de Fernández Ramírez, p. 281. 
Com relação ao marco temporal de anterioridade instaurado pelo imperfecto as noticias são posteriores e a incerteza do condicional é resolvida pelo pretérito.

11. concomitância durativa 2 pela posterioridade 2 (pretérito imperfecto pelo condicional)

Y Carolina, al amparo de la confusión que suele provocar un traslado de esta naturaleza, quiso marcharse alegando que su avión salía dentro de una hora y no estaba segura de ir a encontrar un $\operatorname{taxi}^{94}$.

A probabilidade, que deveria estar expressa pelo condicional, adquire um valor de certeza ao ser usado o imperfecto, salía.

12. anterioridade 2 pela concomitância pontual 2 (pretérito pluscuamperfecto pelo pretérito perfecto simple).

Había perdido el pasaporte días antes de coger el avión.

O fato da perda do passaporte é concomitante a um momento de referência passado expresso por días antes de coger el avión. O uso do pretérito pluacuamperfecto pretende destacar a anterioridade.

\section{3. anterioridade 2 pela concomitância durativa 2 (pretérito pluscuamperfecto pelo pretérito imperfecto).}

Algunos trabajadores se esforzaban mucho mientras que otros apenas habían movido un dedo.

O pretérito pluscuamperfecto destaca o aspecto acabado da ação.

${ }^{94}$ FDEZ. de CASTRO, Javier (1987). La novia del Capitan. Madrid: Mondadori (p. 298) (CREA 10/03/2007) 
14. posterioridade 2 pela concomitância pontual 2 (condicional pelo pretérito perfecto simple).

Él la ha dejado ir: ése fue un error de cálculo. Con la afrenta de Momir, la mujer ya habría tenido bastante ${ }^{95}$.

O marco temporal expresso pela concomitância pontual 2 inscreve o condicional composto, com o uso desse tempo o enunciador vem nos dizer que o fato está por confirmar, cria o efeito de sentido de incerteza.

15. posterioridade 2 pela concomitância durativa 2 (condicional pelo pretérito imperfecto).

Esto sucedía el 4 de mayo de 1937, calculo serían las siete de la $\operatorname{tarde} e^{96}$.

A data ancora o texto na anterioridade, por tanto deveria empregar-se o pretérito imperfecto, o uso do condicional cria um efeito de sentido de incerteza.

16. anterioridade 2 pela posterioridade 2 (pretérito pluscuamperfecto pelo condicional).

Al año siguiente entrará en la universidad y antes de concluirla comenzará a trabajar en el despacho de su padre.

O marco temporal situa o acontecimento na posterioridade, começar a trabalhar é um ato anterior a concluir o curso universitário, deveria usar-se portanto um futuro compuesto.

${ }^{95}$ MARTíNEZ, Tomás Eloy (2002). El vuelo de la reina. Madrid: Alfaguara (p. 277) (CREA 10/03/2007). 
17. posterioridade 2 pela anterioridade 2 (condicional pelo pretérito pluscuamperfecto).

Me pregunté cuándo habría sido la última vez que el padre Fernando había abandonado el recinto del colegio de San Gabriel $^{97}$.

O verbo, habría sido, expresa anterioridade com o sentido adicional de incerteza ao usar o condiconal.

18. concomitância 3 pela anterioridade 3 (futuro simple pelo futuro compuesto).

19. anterioridade 3 pela concomitância 3 (futuro compuesto pelo futuro simple).

Si para entonces no hemos acabado, habrá sido nuestro último trabajo en esta empresa.

Dentro do marco temporal da posterioridade o uso do futuro compuesto exprime o sentido de que com certeza será o último trabalho nessa empresa, serão despedidos.

20. anterioridade 3 pela posterioridade 3 (futuro compuesto pelo futuro simple).

Si conseguimos ese contrato, habremos alcanzado nuestros objetivos.

96 OLAIZOLA, José Luis (1990). La guerra del general Escobar. Barcelona: Planeta p. 123 (CREA $10 / 03 / 2007)$.

${ }^{97}$ RUIZ ZAFÓN, Carlos (2003). La sombra del viento. Barcelona: Planeta (p. 25) (CREA 08/03/2007) 
Alcanzar os objetivos é posterior ao fato de conseguir esse contrato, no entanto o uso do futuro compuesto cria o efeito de sentido de certeza, indica os resultados certos da ação futura.

21. posterioridade 3 pela anterioridade 3 (futuro simple pelo futuro compuesto).

Al día siguiente de tu muerte, tus enemigos empezarán a reaccionar y, antes de enterrarte, te quitarán a tu hijo y, después, lo matarán. ${ }^{98}$

A respeito do marco temporal futuro, antes de enterrarte, quitar e matar são acontecimentos anteriores o que dá uma idéia de probabilidade.

\section{B) Neutralizações entre os mesmos termos de categoria topológica de subsistemas diferentes.}

1. concomitância 1 pela concomitância pontual 2 (presente pelo pretérito perfecto simple). É o chamado presente histórico.

En 1939 finaliza la Guerra Civil española.

Este presente pode ser usado na conversação ou com fins narrativos. Quando usado na conversação freqüentemente descreve várias ações sucessivas. Quando usado na narração pode ocorrer também a neutralização do presente pelo pretérito imperfecto.

Cuando la acabo de leer (mi alocución), los buenos escolapios que presiden la mesa callan gravemente (AZORÍN, Las confesiones de un pequeño filósofo, XV; OC, II, 57) ${ }^{99}$

\footnotetext{
${ }^{98}$ Adaptado de Fiorin (2001, p.207).

${ }^{99}$ Exemplo tomado de Salvador Fernandez Ramírez, Gramática española (p. 220)
} 
No exemplo aparece o pretérito perfecto simple neutralizado pelo presente (acabo) e posteriormente é o pretérito imperfecto o tempo que sofre a neutralização pelo presente (presiden e callan)

Os usos do presente histórico narrativo são favorecidos por algumas expressões:

En esto + presente

En esto oigo un estruendo, eran dos coches que se chocaban.

He(te) aquí que + presente

He aquí que un día, me dice, sin más, que ya no me quiere.

De prontol de súbito + presente

De pronto me encuentro cara a cara con aquel hombre de aspecto siniestro. Fue uno de los peores momentos de mi vida.

Cuando + pretérito (ou imperfecto) + presente

Cuando estuvo (estaba) todo preparado, coge sus cosas y se va sin dar ninguna explicación.

Imperfecto + cuando + presente

Iba a comprar las entradas cuando recibo una llamada diciendo que no viene.

2. concomitância 1 pela concomitância durativa $\mathbf{2}$ (presente pelo pretérito imperfecto) neutralização de um tempo enunciativo e um enuncivo correspondentes. 
Em ocasiões, como já foi sugerido anteriormente, o presente histórico neutraliza o pretérito imperfecto em usos narrativos. Depende da natureza do verbo ou do contexto para interpretar que estamos diante de uma ação imperfectiva. É freqüente seu uso nas descrições, o enunciador pretende assim aproximar a narração do público.

Suenan las campanas en el pueblo vecino, el llanto de un niño desgarra la noche. Todos sabíamos quien era el muerto.

Os acontecimentos expressam a concomitância com um momento de referência anterior. Nesse contexto o presente neutraliza o pretérito imperfecto (suenan e desgarran) para aproximar a narração.

O presente pode neutralizar o imperfecto de situación abolida (Fernandez Ramirez, 1986: 233) com o verbo hacer (hacer + período de tempo) em determinados contextos.

Hace un año que no comía carne.

Hacía un año que no comía carne.

Nesse caso é possível a neutralização, o verbo hacer pode se referir ao momento anterior ou ao momento da enunciação.

Já no seguinte exemplo o uso do presente e do imperfecto implicam sentidos diferentes.

Hace lo menos un año que no la veo.

Hacía lo menos un año que no la veía.

É imprescindível nesse exemplo o uso do imperfecto para denotar que a ação negada foi realizada. Não é possível a neutralização. 
3. concomitancia puntual 2 pela concomitancia 1 (pretérito perfecto simple pelo presente).

4. concomitância 2 pela concomitância 1 (pretérito imperfecto pelo presente). Neutralização de um tempo enuncivo e outro enunciativo correspondentes.

É o caso do imperfecto de cortesia, designa fatos ou intenções pretéritas com um efeito recente.

¿Qué deseaba tomar?

O imperfecto desiderativo expressa desejo pode neutralizar tanto um presente quanto um condicional simple.

¿Qué bien me venía un descanso!

O imperfecto usado para expressar ironia ou reprovação.

Me extrañaba que fuese tan generoso.

Lo que me imaginaba.

O imperfecto de explicación o excusa referido a fatos que estão acontecendo ou que são próximos do momento da enunciação.

-Pero, ¿qué haces?

-Estaba intentando arreglarlo.

5. anterioridade 1 pela concomitância 2 (pretérito perfecto compuesto pelo pretérito perfecto simple). Neutralização de um termo da categoria topológica e outro de um subsistema temporal distinto.

O pretérito perfecto compuesto aparece nas situações em que não interessa estabelecer uma correlação temporal, nem estabelecer um fato 
cronologicamente, o único interesse é mostrar sua aparição ou sua existência. Entraria no campo do perfercto simple que é o tempo que naturalmente é usado para expressar acontecimentos no passado.

Movimientos orogénicos importantes [...] han producido un conjunto de pliegues tumbados y corridos (Hdez. Pacheco, Relieve peninsular, 60) ${ }^{100}$.

6. posterioridade 1 pela posterioridade 2 (futuro simple pelo condicional).

En 1936 Azaña hablará al pueblo.

O efeito de sentido criado pelo uso do futuro simple é aproximar a enunciação com a certeza de que o fato aconteceu pois o marco de referência é a posteridade. Tem o mesmo efeito que o presente histórico. Nos textos históricos é utilizado para descrever as conseqüências que decorrem dos fatos.

7. posterioridade 2 pela posterioridade 1 (condicional pelo futuro simple)

[...] los hombres que hoy clamaban su muerte serían los mismos que durante siglos lo llorarían ${ }^{101}$.

O marco de referência estabelecido pelo advérbio hoy faz interpretar que os serían e llorarían deverían ser futuros. Se o futuro já expressa a probabillidade o futuro do pretérito deixa uma marca de incerteza ainda maior.

8. concomitância 1 pela concomitância 3 (presente pelo futuro simple)

Cuando me llamen, voy

${ }^{100}$ Exemplo tomado de Fernández Ramírez, (1986, p.245).

${ }^{101}$ GAMBOA, Santiago (1998). Páginas de vuelta. Barcelona, Mondaroi (p.338) (CREA 05/03/2007) 
Utilizado nas orações temporais produz um efeito de sentido de determinação, certeza, na realização da ação futura.

9. concomitância 3 pela concomitância 1 (futuro simple pelo presente)

Un día te tratará como a una reina y otro como un trapo.

O futuro substitui o presente habitual para dar o efeito de sentido de probabilidade ou incerteza.

10. anterioridade 1 pela anterioridade 3 (pretérito perfecto compuesto pelo futuro compuesto).

11. anterioridade 3 pela anterioridade 1 (futuro compuesto pelo pretérito perfecto compuesto).

Miró a su alrededor espantado y se dijo a si mismo, habrá sido un sueño.

O futuro compuesto expressa uma afirmação atenuada.

12. posterioridade 3 pela posterioridade 1 (futuro simple enucivo pelo futuro simple enunciativo).

Mañana es la inauguración oficial y después habrá un almuerzo para los participantes.

Ao utilizar um presente com valor de futuro a posterioridade em relação a ele é expressa por um futuro do sistema enuncivo. A certeza da ação futura expressa em presente estende-se para o futuro enuncivo. 
13. concomitância pontual 2 pela concomitância 3 (pretérito perfecto simple pelo futuro simple).

14. concomitância durativa 2 pela concomitância 3 (pretérito imperfecto pelo futuro simple enuncivo).

15. concomitância 3 pela concomitância pontual 2 (futuro simple pelo pretérito perfecto compuesto).

Carmina conoció al que sería su esposo en plena Guerra Civil, tendrán su primer hijo un año después de finalizada la contienda.

O marco temporal é a anterioridade estabelecida pelo pretérito perfecto simple, conoció. O futuro tendrán expressa um fato posterior ao casamento mas anterior à narração.

16. concomitância 3 pela concomitância durativa 2 (pretérito pluscuamperfecto pelo futuro compuesto)

Pasado mañana, a esta hora, he acabado el trabajo que había comenzado temprano.

O verbo había comenzado expressa uma relação de anterioridade em relação com o marco temporal futuro, pasado mañana, criando o efeito de sentido de uma certeza absoluta pois está expresso por um pretérito.

17. anterioridade 3 pela anterioridade 2 (futuro compuesto pelo pretérito pluscuamperfecto).

A esa edad era fácil caer en la tentación, anda que no habremos caído veces. 
O marco de referencia temporal é a anterioridade, o futuro expressa a possibilidade do número de vezes impreciso que pode

18. posterioridade 2 pela posterioridade 3 (condicional simple pelo futuro simple enuncivo).

Si sembrasemos paz, recogeríamos los frutos que alimentarían el corazón de los hombres.

Contextualizando o exemplo no discurso indireto livre, os tempos enunciativos passam a ser enuncivos. Desde este ponto de vista, sembrásemos instala no enunciado um marco temporal futuro em relação ao qual recogeríamos é concomitante e alimentarían posterior. Ao ser alterada a situação de enunciação o futuro é expresso pelo condicional.

19. posterioridade 3 pela posterioridade 2 (futuro simple pelo condicional).

No les gustó la actuación del jefe frente a los trabajadores, que ellos, sin duda, repetirán.

Em relação ao marco temporal pretérito, a ação de repetir o comportamento indica posterioridade. A escolha do futuro pelo condicional deve-se a que o primeiro insere a ação no tempo e o segundo expressa duração.

20. anterioride 3 pela posterioridade 2 (futuro compuesto pelo condicional compuesto)

Qué le habrá visto en la cara cuando le dio ese abrazo ${ }^{102}$;

${ }^{102}$ CHACÓN, Dulce (2002). La voz dormida. Madrid: Alfaguara (p. 116) (CREA 15/03/2007) 
O marco de referência passado exigiria o uso de um condicional compuesto, o uso do futuro compuesto expressa a certeza do que algo foi percebido para dar esse abraço.

C) Neutralizações entre termos diferentes da categoria topológica de subsistemas distintos.

1. concomitância 1 pela anterioridade 2 (presente pelo pretérito mais que perferfeito).

2. anterioridade 2 pela concomitância 1 (pretérito pluscuamperfecto pelo presente)

3. concomitância 1 pela posterioridade 2 (presente pelo condicional compuesto).

4. posterioridade 2 pela concomitancia 1 (condicional simple pelo presente). Neutralização de um termo da categoria topológica com outro de um sistema ou subsistema distinto.

O condicinal simple usado para expressar desejo.

¡Qué bien me vendrían unas vacaciones!

5. concomitancia durativa 2 pela anterioridade 1

6. posterioridade 2 pela anterioridade 1 (futuro pelo pretérito perfecto compuesto).

7. posterioridade 1 pela concomitância pontual 2 (futuro do presente pelo pretérito perfecto simple). 
8. concomitância durativa 2 pela posterioridade 1 (pretérito imperfecto pelo futuro simple).

9. concomitância 1 pela anterioridade 3 (presente pelo futuro compuesto).

10. anterioridade 3 pela concomitância 1 (futuro compuesto pelo presente).

11. concomitância 1 pela posterioridade 3 (presente pelo futuro simple)

12. posterioridade 2 pela concomitância 1 (condicional pelo futuro simple)

13. posterioridade 2 pela anterioridade 3 (condicional pelo futuro simple).

14. anterioridade 1 pela anterioridade 3 (pretérito perfecto simple pelo futuro compuesto).

Sólo por haber visto el cuerpo del mismo mártir, aunque no se atrevieron a tocarlo, dentro de diez días murieron todos, para que ninguno quedase por testigo de haberlo visto ${ }^{103}$.

O momento de referencia é a anterioridade expressa pelo pretérito perfecto simple, o fato de expressar a posterioridade com o pretérito no lugar de usar o futuro composto indica que já teve lugar o fato que ainda deve acontecer.

15. anterioridade 3 pela concomitância pontual 2 (futuro compuesto pelo pretérito perfecto simple).

¡Qué casualidad! Yo estuve allí el mes pasado. ¿Cómo no nos habremos visto? ${ }^{104}$

${ }^{103}$ TORBADO, Jesús (1994). El peregrino. Barcelona: Planeta, (p. 412) (CREA 15/03/2007)

${ }^{104}$ MONCADA, Santiago (1993). Caprichos. Madrid, SGAE, p. 52 (CREA 15/03/2007) 
Foram examinadas as embreagens, embora não achamos exemplos para todas as cominações cuja construção é possível não espanhol. No entanto, o modelo teórico conseguiu explicar os exemplos do corpus apresentados na pesquisa realizada e prevê que pode haver outros que não foram achados. Uma das maiores dificuldades na busca de exemplos foi a própria configuração do modelo de busca do CREA (Corpus de referência del español actual). O corpus realiza a busca por palavras e expressão e não por modelos de estruturas, daí a dificuldade. Por outro lado, o corpus permitiu usar como exemplos autores dos diferentes países de língua espanhola, o que confirma a unidade da língua espanhola ao tempo que reconhece as variantes na norma culta.

\section{Conclusão}

Ao longo deste trabalho tentamos mostrar e verificar que o modelo teórico apresentado por José Luiz Fiorin no seu livro As astúcias da enunciação é aplicável ao sistema verbal do español. 
Foi constatado que o tempo lingüístico é uma construção da instancia da enunciação e que o eixo criado pelo agora, momento da enunciação, e o seu contraposto então, permeia a organização completa do sistema temporal.

A categoria de tempo apresenta um sistema enuncivo que vincula os tempos da enunciação enunciada, concomitantes ao momento da enunciação e um sistema enuncivo que organiza os tempos do enunciado enunciado, não concomitantes ao momento da enunciação, seja em forma de anterioridade ou de posterioridade.

Paralelamente foram estudadas as relações que a categoria adverbial tem com o momento da enunciação, constatando que, de modo similar à categoria verbal, os advérbios também se apresentam em um sistema enunciativo e um sistema enuncivo.

A respeito das peculiaridades do sistema verbal do español foram destacadas as relações que o pretérito perfecto simple e o pretérito perfecto compuesto mantem com o momento da enunciação por ser esta uma questão abordada pelos estudiosos de uma forma diferenciada. Constatamos neste ponto que:

- a relação de anterioridade da concomitância é exprimida pelo pretérito perfecto compuesto (he trabajado).

- a relação de concomitância da anterioridade é exprimida pelo pretérito perfecto simple (trabajé).

No entanto, quando os advérbios do sistema enunciativo aparecem na cena enunciativa esses tempos verbais sofrem uma mudança representação do esquema, já que o primeiro, pretérito perfecto compuesto (he trabajado), ocorre com os advérbios que expressam a concomitância da concomitância, enquanto o segundo, pretérito perfecto simple (trabajé), é usado com os advérbios que exprimem a anterioridade da concomitância. Foi apontada uma possível solução que fizesse prevalecer a coerência do modelo teórico sem que cada uma das respectivas formas verbais perdesse as qualidades que as definem. Assim o pretérito perfecto simple (trabajé) poderia expressar nesses casos concretos, com os advérbios que expressam anterioridade da concomitância, a anterioridade da concomitância fazendo, desse modo, prevalecer o simulacro da enunciação.

Para completar a aplicação do modelo teórico no sistema verbal do español, foram estudados os câmbios que acontecem na debreagem de segundo grau, quando o narrador 
delega a voz a um interlocutor, estilo direto. Verificando-se, no caso do estilo indireto, as mudanças que ocorrem na passagem de dois momentos de enunciação para um só.

O modo subjuntivo mereceu um capítulo para estudar as correlações temporais e as relações que os tempos deste modo estabelecem com o verbo principal e, portanto, com o momento de referência dele.

Finalmente o capítulo dedicado às neutralizações foi um dos mais difíceis no que respeita a busca de exemplos no corpus. O corpus utilizado, textos literários escritos de meados do século xx até o momento atual, foi fundamental para verificar que uma língua como o español conserva a sua unidade em uma língua modelo. No entanto, a pesar da busca exaustiva no Corpus de Referencia del Español Actual (CREA), não foram achados todos os casos das neutralizações que são plausíveis de acontecerem no español por causa do modelo de busca configurado na utilização do próprio corpus. O modelo teórico conseguiu explicar os exemplos do corpus apresentados na pesquisa realizada e prevê que pode haver outros que não foram achados.

O presente trabalho apresenta-se como uma ferramenta para estudiosos do espanhol, levantando algumas questões a serem discutidas e (re)avaliadas por serem relevantes ao sistema verbal do espanhol. É esta uma ferramenta que pode ser de considerável ajuda aos estudante de espanhol como segunda língua, já que os esquemas desenvolvidos pretendem clarificas qualquer tipo de dúvida a respeito da relação de uns tempos verbais com outros partindo do momento da enunciação.

\section{BIBLIOGRAFIA}


ALARCOS LLORACH, E. (1994). Gramática de la Lengua Española Real Academia Española. Madrid: Espasa Calpe, (Colección Nebrija y Bello).

ÁLVAREZ MARTÍNEZ, M. A. (1994). El advérbio. Cuadernos de Lengua Española. Madrid: Arco Libros.

BARROS, D. L. P. (1988). Teoria do discurso. São Paulo: Atual. (2000). Teoria semiótica do texto. São Paulo: Ática.

BELLO, A. (2004). Gramática de la Lengua Castellana. Madrid: EDAF.

BENVENISTE, E. (1995). Problemas de Lingüística General I. Campinas: Pontes. (1989). Problemas de Lingüística General II. Campinas: Pontes.

BOSQUE, I. (ed) (1990). Tiempo y aspecto en español. Madrid: Cátedra.

CARTAGENA, N. "Los tiempos compuestos" em Gramática Descriptiva de la Lengua Española. (ed. Ignacio Bosque e Violeta Demonte). Madrid: Espasa.

DISCINI, N. (2003). O estilo nos textos. São Paulo: Contexto.

FERNÁNDEZ RAMIREZ, S. (1986). Gramática Española: El verbo y la oración. Madrid: Arcos.

FIORIN, J. L. (2001). As astúcias da enunciação. As categorias de pessoa, espaço e tempo. São Paulo: Ática. (2001). Elementos de análise do discurso. São Paulo: Contexto. (1998). Linguagem e ideologia. São Paulo: Ática.

GARCÍA SANTOS, J. F. (1993). Sintaxis del español. Nivel de perfeccionamiento. Madrid: Santillana.

GARMADI, J. (1983). Introdução à sociolingüística. Lisboa: Publicações Dom Quixote. GÓMEZ TORREGO, L. (2002) Gramática didáctica del español. Madrid: Ediciones SM. HJELMSLEV, L. (1975) Prolegômenos a uma teoria da linguagem. São Paulo: Perspectiva.

HUE FANOST, C. (1994). El advérbio. Madrid: SGEL.

LAPESA, R. (1986). Historia de la Lengua Española. Madrid: Gredos. (8 edição).

LODARES, J. R. (2001). Gente de Cervantes. Historia humana del idioma español. Madrid: Taurus.

LOZANO, L. (2005). "Hacia una única explicación del subjuntivo aplicado a la adquisición de E/LE” em: Cuadernos Cervantes de la Lengua Española. Año nº 11, número: 56. 
MALDONADO GONZÁLEZ, C. (1999). "Discurso directo y discurso indirecto" (35513595). Em: Gramática descriptiva de la lengua española. Real Academia Española, colección Nebrija y Bello. Madrid: Espasa, (3 ${ }^{a}$ reimpresão, 2000).

MORENO FERNÁNDEZ, Frco. (2000). Qué español enseñar. Madrid: Arco (Cuadernos de DIDÁCTICA del español/LE).

REAL ACADEMIA ESPAÑOLA. (1986) Esbozo de una Nueva Gramática de la Lengua Española. Madrid: Espasa Calpe. (1ª edición 1973).

(1999). Gramática descriptiva de la lengua española. Ignacio Bosque e Violeta Demonte (eds.). Madrid: Espasa Calpe. (3 vols.).

(1992). Diccionario de la Lengua Española. Madrid: Espasa Calpe (21 ${ }^{\mathrm{a}}$ edición)

REYES, G. (1995). Los procedimientos de cita: estilo directo y estilo indirecto. Cuadernos de Lengua Española. Madrid: Arco Libros (2 edición).

(1996). Los procedimientos de cita: citas encubiertas y ecos. Cuadernos

de Lengua Española. Madrid: Arco Libros (2 $2^{\text {a }}$ edición).

ROJO, G. (1990). "Relaciones de temporalidad y aspecto en el verbo español” em: Tiempo y aspecto en español. (ed. Ignacio Bosque). Madrid: Cátedra Lingüística.

ROJO, G. \& VEIGA, A. (1999). "El tiempo verbal. Los tiempos simples” em Gramática Descriptiva de la Lengua Española. (ed. Ignacio Bosque e Violeta Demonte). Madrid: Espasa.

RUIZ CAMPILLO, (2001). "El subjuntivo es lógico: una actividad de concienciación”. Cuadernos Cervantes, $\mathrm{n}^{\mathrm{o}}$ 2, maio, p. 33-36.

SASTRE, Ma A. (1997). El subjuntivo en español. Libros del español ELE. Salamanca: Ediciones Colegio de España.

\section{OBRAS LITERÁRIAS DE REFERÊNCIA}

GALEANO, E. (1987). Vagamundo y otros relatos. Montevideo: Ediciones el Chanchito. GARCÍA MÁRQUEZ, G. (1982). Cien años de soledad. ( $8^{\mathrm{a}}$ edic). Madrid: Austral. 
GIRONDO, O. (1995). Veinte poemas para ser leídos en el tranvía. Calcomanías y otros poemas. Madrid: Visor.

MARSÉ, J. (1982). Un día volveré. Barcelona: Plaza \& Janés.

MONTERROSO, A. (1991). La Oveja negra y demás fábulas. Barcelona: Anagrama.

MUÑOZ MOLINA, A. (1990). Beltenebros. (8º edic.) Barcelona: Seix Barral.

PIGLIA, R. (2000). Plata quemada. (12ª edic.). Buenos Aires: Planeta.

SÁBATO, E. (2002). La resistencia. Buenos Aires: Planeta.

SALINAS, P. (1985). La voz a ti debida. Razón de amor. Madrid: Castalia.

VAlleJO, C. (1987). Poemas Humanos. España, aparta de mí este cáliz. Madrid: Castalia.

\section{OBRAS LITERÁRIAS DE REFERÊNCIA CONSULTADAS EN EL CREA (referências sem número de página )}

REAL ACADEMIA ESPAÑOLA: Banco de datos (CREA) [on line]. Corpus de referencia del español actual. <http://www.rae.es>

AGUILAR CARMIN, H. (1995). El error de la luna. México DF: Alfaguara.

ALLENDE, I. (1995). La casa de los espíritus. Barcelona: Plaza y Janés.

ARIAS, M. (1991). El silencio de las palabras. Barcelona: Destino.

CEBRIÁN, J. L. (1986). La rusa. Barcelona: Círculo de Lectores.

CHACÓN, D. (2002). La voz dormida. Madrid: Alfaguara.

FDEZ. de CASTRO, J. (1987). La novia del Capitan. Madrid: Mondadori.

ECHENIQUE, B. (1995). La vida exagerada de Martín Romaña. Barcelona: Alfaguara.

ECHENIQUE, B. (1995). La vida exagerada de Martín Romaña. Barcelona: Alfaguara.

GAMBOA, S. (1998). Páginas de vuelta. Barcelona: Mondadoroi.

GARCÍA SÁNCHEZ, J. (1991). La historia más triste. Barcelona: Anagrama.

GONZÁLEZ LEÓN, A. (1995). Viejo. Madrid: Alfaguara.

GONZÁLEZ, E. (1999). Quien como Dios. Madrid: Espasa Calpe. 
HIDALGO, M. (1998). Azucena que juega al tenis. Madrid: Mondadori.

JIMÉNEZ-ARNAU, J. (1977). Las Islas Transparentes. Barcelona: Destino.

LABARCA, E. (1994). Butamalón. Madrid: Anaya e Mario Muchnik.

MARSÉ, J. (1996). El embrujo de Shangai. Barcelona: Plaza \& Janés.

MARSÈ, J. (2000) Rabos de lagartija. Barcelona: Lumen.

MARTÍN DEL CAMPO, D. (1976). Las rojas son las carreteras. México D.F.: Joaquín Mortiz.

MARTÍNEZ DE PISÓN, I. (1994). La ternura del dragón. Barcelona: Anagrama.

MARTÍNEZ, T. E. (2002). El vuelo de la reina. Madrid: Alfaguara.

MENDOZA, E. (1994). La verdad sobre el caso Savolta. Barcelona: Seix Barral.

MERINO, J. M. (1995). La orilla oscura. Madrid: Alfaguara.

MILLÁS, J. J. (2002). Dos mujeres en Praga. Madrid: Espasa Calpe.

MOIX, A. Ma. (1994). Vals negro. Barcelona: Lumen.

MOIX, T. (2002). El arpista ciego. Una fantasía del reinado de Tutankamon. Barcelona:

Planeta.

MONCADA, S. (1993). Caprichos. Madrid: SGAE.

MORALES, A. (1979) La verdad sin voz. México D.F.: Joaquín Mortiz.

OLAIZOLA, J. L. (1990). La guerra del general Escobar. Barcelona: Planeta.

POMBO, Á. (2004). Una ventana al norte. Barcelona: Anagrama.

PUERTOLAS, S. (1993) Queda la noche. Barcelona: Planeta.

REGÁS, R. (1994) Azul. Barcelona: Destino.

RICO GODOY, C. (1995). Cómo ser una mujer y no morir en el intento. Madrid:

Ediciones Temas de Hoy.

ROSSI, A. C. (1985) María la noche. Barcelona: Lumen.

RUIZ ZAFÓN, C. (2003). La sombra del viento. Barcelona: Planeta.

SOMOZA, J. C. (2000). La caverna de las ideas. Madrid: Alfaguara.

TORBADO, J. (1994). El peregrino. Barcelona: Planeta.

VALLEJO-NÁGERA, J. A.(1994) Yo, el rey. Barcelona: Planeta.

VARGAS LLOSA, M. (1996). La tia Julia y el escribidor. Barcelona: Seix Barrarl.

VÁZQUEZ, A. (1990). La vida perra de Juanita Narboni. Barcelona: Planeta. 